Wetlands Regulatory Assistance Program

A Regional Guidebook for Applying the Hydrogeomorphic Approach to the Functional Assessment of Forested Wetlands in Alluvial Valleys of East Texas

Hans M. Williams, Adam J. Miller, Rachel S. McNamee,

October 2010

and Charles V. Klimas 


\section{A Regional Guidebook for Applying the Hydrogeomorphic Approach to the Functional Assessment of Forested Wetlands in Alluvial Valleys of East Texas}

Hans M. Williams, Adam J. Miller, and Rachel S. McNamee

Arthur Temple College of Forestry and Agriculture

Stephen F. Austin State University

419 East College Street

Nacogdoches, TX 75962-6109

Charles V. Klimas

Environmental Laboratory

U.S. Army Engineer Research and Development Center

3909 Halls Ferry Rd

Vicksburg, MS 39180-6199

Final report

Approved for public release; distribution is unlimited.

\footnotetext{
Prepared for Texas Department of Environmental Quality

Environmental Protection Agency Region 6

U.S. Army Corps of Engineers
} 


\begin{abstract}
The Hydrogeomorphic (HGM) Approach is a method for developing and applying indices for the site-specific assessment of wetland functions. The HGM Approach was initially designed to be used in the context of the Clean Water Act Section 404 Regulatory Program permit review process to analyze project alternatives, minimize impacts, assess unavoidable impacts, determine mitigation requirements, and monitor the success of compensatory mitigation. However, a variety of other potential uses have been identified, including the design of wetland restoration projects, and management of wetlands.
\end{abstract}

This Regional Guidebook presents the HGM Approach for assessing the functions of most of the wetlands that occur in alluvial valleys of East Texas. The report begins with an overview of the HGM Approach and then classifies and characterizes the principal wetlands that have been identified within the region. Detailed HGM assessment models and protocols are presented for three of those wetland types, or subclasses: Low-gradient Riverine, Mid-gradient Riverine, and Connected Depression. For each wetland subclass, the guidebook presents (a) the rationale used to select the wetland functions considered in the assessment process, (b) the rationale used to select assessment model variables, (c) the rationale used to develop assessment models, and (d) the functional index calibration curves developed from reference wetlands that are used in the assessment models. The guidebook outlines an assessment protocol for using the model variables and functional indices to assess each of the wetland subclasses. The appendices provide field data collection forms and spreadsheets for making calculations.

DISCLAIMER: The contents of this report are not to be used for advertising, publication, or promotional purposes. Citation of trade names does not constitute an official endorsement or approval of the use of such commercial products. All product names and trademarks cited are the property of their respective owners. The findings of this report are not to be construed as an official Department of the Army position unless so designated by other authorized documents. 


\section{Contents}

Figures and Tables..........................................................................................................................................vi

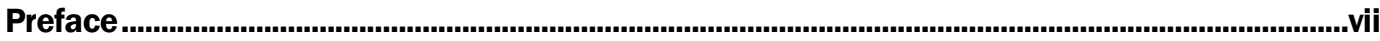

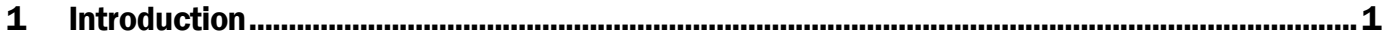

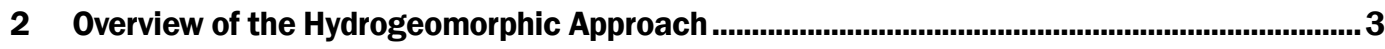

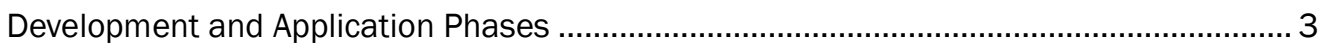

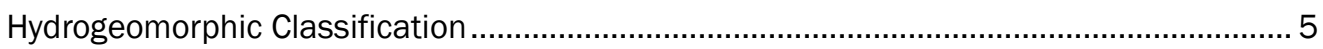

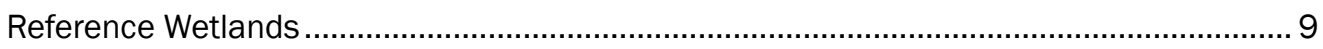

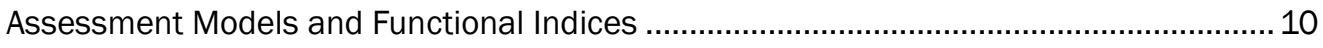

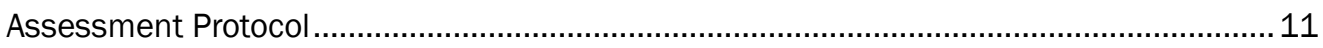

3 Characterization of Wetland Subclasses in the Alluvial Valleys of East Texas .......................12

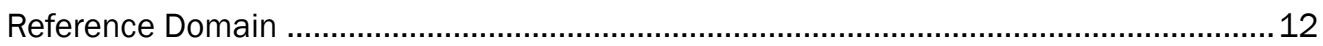

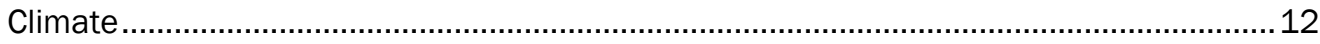

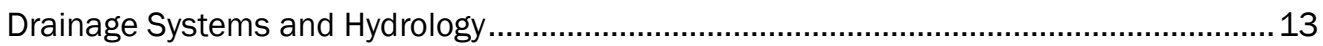

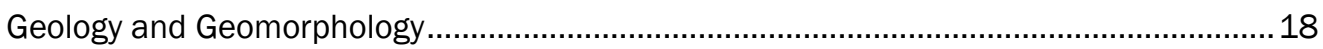

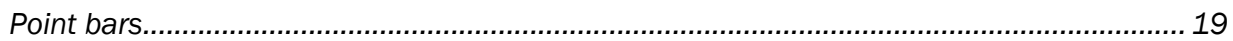

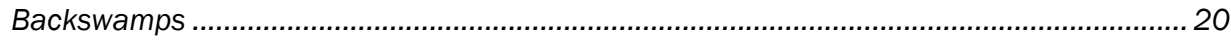

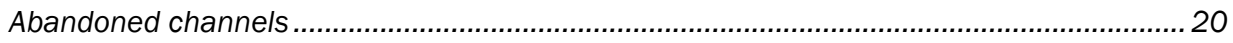

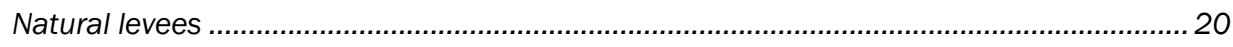

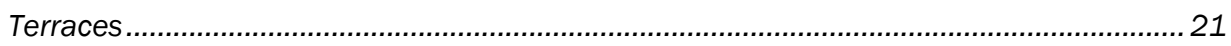

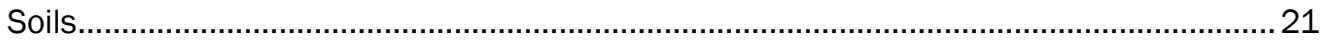

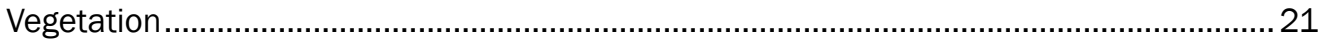

Definition and Identification of the HGM Classes and Subclasses..................................25

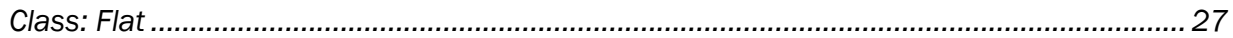

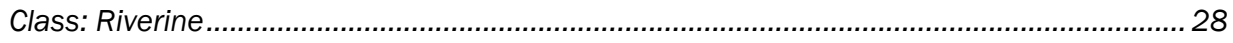

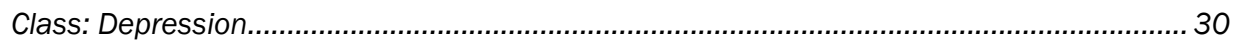

Class: Fringe

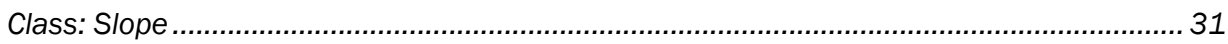

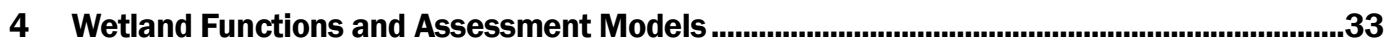

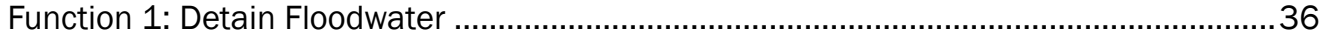

Definition and applicability ......................................................................................

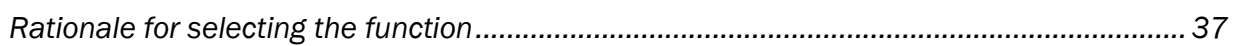

Characteristics and processes that influence the function .................................................37

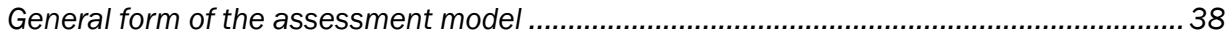

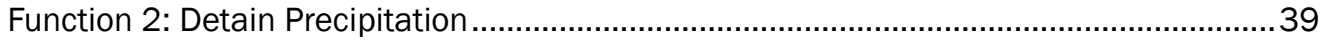

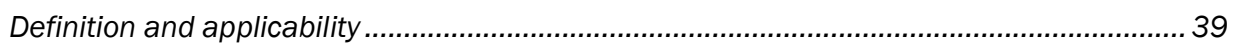

Rationale for selecting the function ................................................................................... 40

Characteristics and processes that influence the function ................................................... 40

General form of the assessment model ............................................................................. 40 


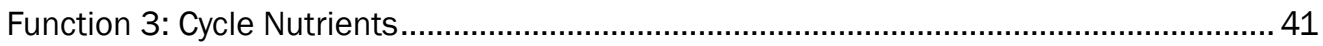

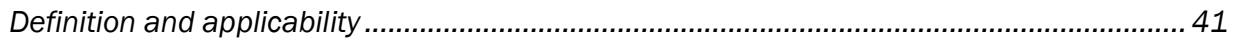

Rationale for selecting the function ................................................................................ 42

Characteristics and processes that influence the function ................................................... 42

General form of the assessment model ........................................................................ 43

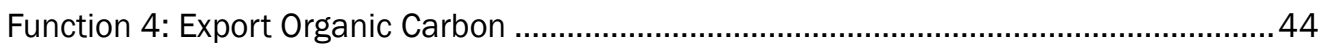

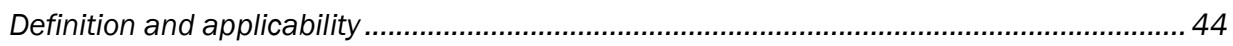

Rationale for selecting the function............................................................................. 44

Characteristics and processes that influence the function ................................................... 45

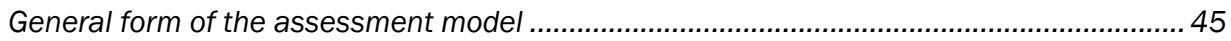

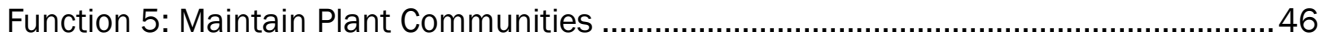

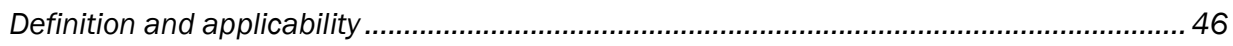

Rationale for selecting the function ........................................................................... 47

Characteristics and processes that influence the function .................................................. 47

General form of the assessment model ....................................................................... 47

Function 6: Provide Habitat for Fish and Wildlife ......................................................... 49

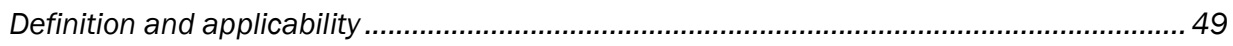

Rationale for selecting the function ................................................................................... 49

Characteristics and processes that influence the function ................................................... 49

General form of the assessment model ......................................................................... 52

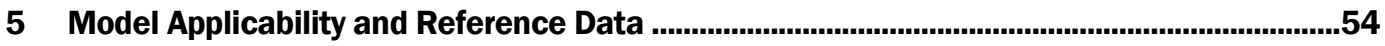

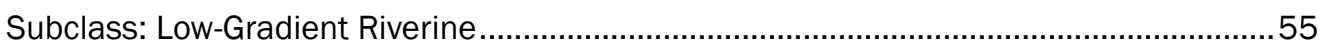

Subclass: Mid-Gradient Riverine .......................................................................... 58

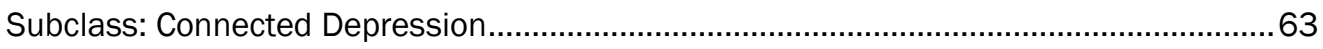

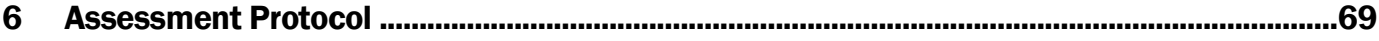

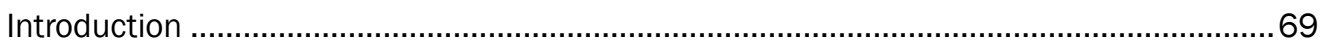

Document the Project Purpose and Characteristics ..................................................... 70

Screen for Red Flags ................................................................................................... 71

Define Assessment Objectives and Identify Regional Wetland Subclass(es)

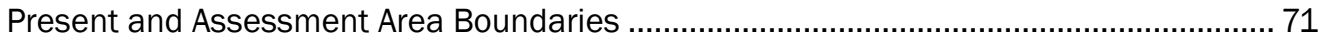

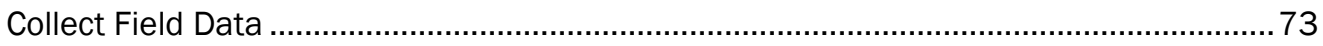

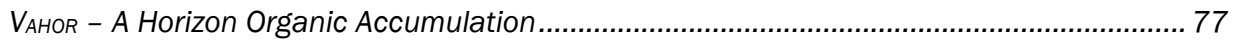

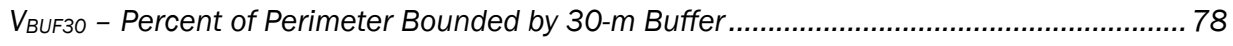

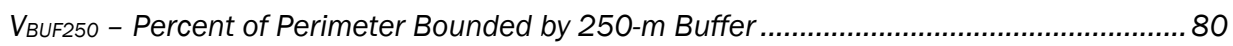

$V_{\text {COMP }}$ - Composition of Tallest Woody Vegetation Stratum ................................................... 81

$V_{\text {DUR }}$ - Change in Growing Season Flood Duration............................................................... 82

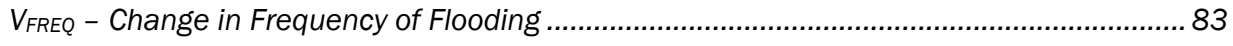

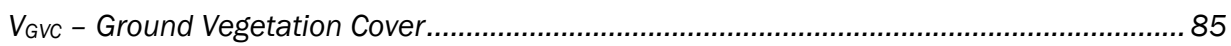

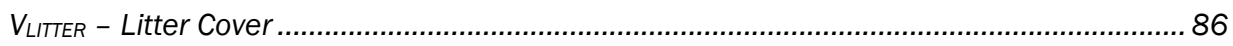

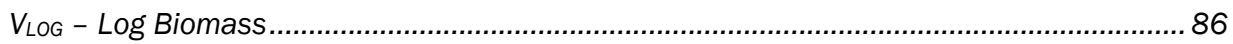

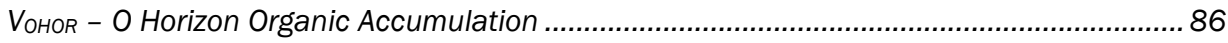

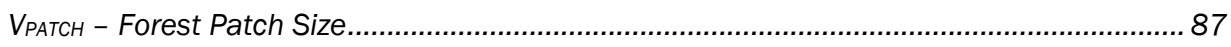

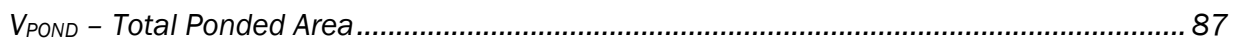

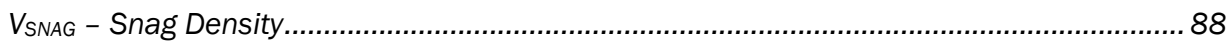

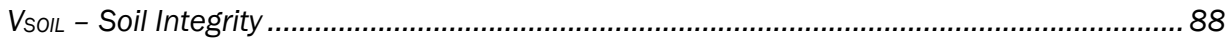




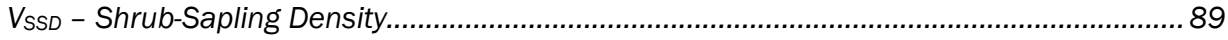

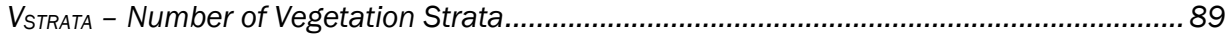

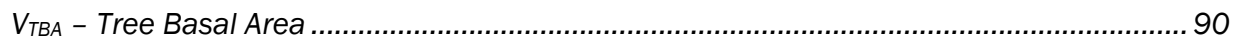

V

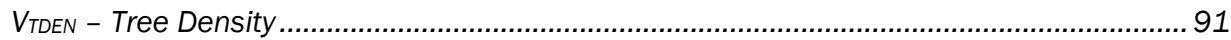

VWD - Woody Debris Biomass and VLOG - Log Biomass ...................................................... 91

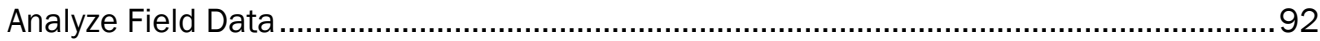

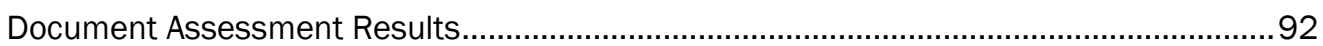

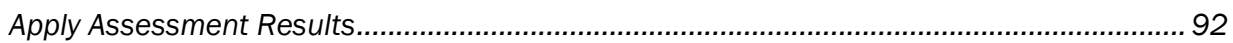

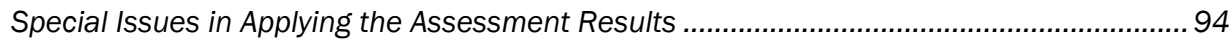

References ........................................................................................................................................... 100

Appendix A: Preliminary Project Documentation and Field Sampling Guidance ...................... 110

Appendix B: Field Data Forms...................................................................................................115

Appendix C: Example Spreadsheet Output Forms ............................................................128

Appendix D: Common and Scientific Names of Plant Species Referenced in Text and

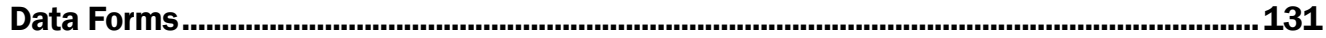

\section{Report Documentation Page}




\section{Figures and Tables}

\section{Figures}

Figure 1. Development and Application Phases of the HGM Approach

Figure 2. Example subindex graph for the Tree Density $\left(V_{\text {TDEN }}\right)$ assessment variable for a particular wetland subclass.

Figure 3. Ecoregions of East Texas .

Figure 4. Major drainage basins of East Texas ......................................................................................14

Figure 5. Major aquifers of East Texas ...............................................................................................

Figure 6. Minor aquifers of East Texas .....................................................................................

Figure 7. Typical form and locations of geomorphic and man-made features within river

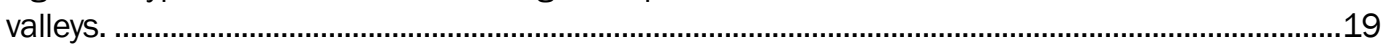

Figure 8. Principal land cover categories in East Texas ..................................................................23

Figure 10. Subindex graphs for Low-Gradient Riverine wetlands ...................................................56

Figure 11. Subindex graphs for Mid-Gradient Riverine Wetlands ...................................................60

Figure 12. Subindex graphs for Connected Depression wetlands ..................................................66

Figure 13. Example sample distribution in three wetland assessment areas ...................................76

Figure 14. Layout of plots and transects for field sampling ................................................................78

Figure 15. Measurement of buffer characteristics......................................................................

Figure 16. Potential variable subindices for different starting return interval frequencies..............85

Figure 17. Projected recovery trajectories for selected assessment variables..................................98

\section{Tables}

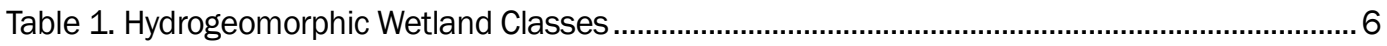

Table 2. Potential Regional Wetland Subclasses in Relation to Classification Criteria.......................... 8

Table 3. Reference Wetland Terms and Definitions ...........................................................................

Table 4. Characteristics of the principal soils of alluvial valleys in East Texas. ...................................22

Table 5. Hydrogeomorphic Classification and Typical Geomorphic Settings of Wetlands in

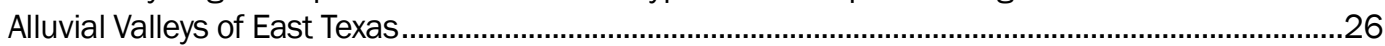

Table 6. Red Flag Features and Respective Program/Agency Authority ............................................72

Table 7. Applicability of Assessment Variables by Regional Wetland Subclass ...................................75 


\section{Preface}

This Regional Guidebook was developed as a cooperative effort between the Texas Commission on Environmental Quality (TCEQ), Austin, TX; Region 6 of the U.S. Environmental Protection Agency (EPA), Dallas, TX; the U.S. Army Corps of Engineers Research and Development Center (USACE-ERDC), Vicksburg, MS; and Stephen F. Austin State University (SFA), Nacogdoches, TX. Funding was provided to SFA by TCEQ, and to TCEQ and ERDC by EPA under a Clean Water Act Section 106 Pollution Control Grant. Additional funding was provided to SFA by Temple-Inland Inc. of Austin, TX and to ERDC by the USACE Wetlands Regulatory Assistance Program. Dr. Hans Williams, SFA, and Dr. Charles Klimas, ERDC, directed the project. Dr. Williams, Adam Miller, and Rachel McNamee, all of SFA, conducted the field studies. All of the authors participated in developing this report. Elizabeth Murray, ERDC, developed the data sheets and spreadsheets for this guidebook, and created some of the figures.

The extent of the study area, wetland classification system, assessment models, model variables, and field indicators used in this document were agreed upon by an interagency group that met in Nacogdoches in November 2006. Organizations represented at that meeting included EPA Region 6, USACE Galveston District, USACE Fort Worth District, ERDC, TCEQ, SFA, Texas Parks and Wildlife Department (TPWD), and Temple-Inland Inc. That group determined that this guidebook should be consistent, to the extent possible, with the Regional Guidebook developed for the nearby West Gulf Coastal Plain Region of Arkansas (Klimas et al. 2005) and every effort has been made to meet that objective. In instances where there were uncertainties as to how to interpret and generalize from field data gathered for the East Texas region, the approach used in Arkansas was adopted to maintain consistency.

The funding and monitoring agencies for this effort were represented by Sylvia Ritzky and Teresita Mendiola (EPA Region 6), Mark Fisher and Peter Schaefer (TCEQ), Robert Lazor (ERDC), and Dr. Dan Spethmann (TempleInland, Inc.). This report was prepared in accordance with guidelines established by ERDC and the methods and protocols used to develop this Guidebook were closely coordinated with similar projects undertaken in the 
Mississippi and Arkansas portions of the Mississippi Alluvial Valley (the Delta Region), and the West Gulf Coastal Plain Region of Arkansas. Therefore, portions of the text and some figures are similar or identical to sections of those HGM guidebooks (Smith and Klimas 2002, Klimas et al. 2004, 2005). The Western Kentucky Regional Guidebook (Ainslie et al. 1999) served as a template for the development of the Mississippi and Arkansas guidebooks and portions of this one. Parts of the discussion in the Western Kentucky Guidebook are included here without significant modification, particularly portions of the wildlife section originally developed by Tom Roberts (Tennessee Technological University) and basic information on the HGM Approach and wetland functions originally developed by R. Daniel Smith, ERDC. 


\section{Introduction}

The Hydrogeomorphic (HGM) Approach is a method for developing functional indices and the protocols used to apply these indices to the assessment of wetland functions at a site-specific scale. The HGM Approach initially was designed to be used in the context of the Clean Water Act Section 404 Regulatory Program, to analyze project alternatives, minimize impacts, assess unavoidable impacts, determine mitigation requirements, and monitor the success of compensatory mitigation. However, a variety of other potential uses have been identified, including the determination of minimal effects under the Food Security Act, design of wetland restoration projects, and management of wetlands.

In the HGM Approach, the functional indices and assessment protocols used to assess a specific type of wetland in a specific geographic region are published in a document referred to as a Regional Guidebook. Guidelines for developing Regional Guidebooks were published in the National Action Plan (National Interagency Implementation Team 1996) developed cooperatively by the U.S. Army Corps of Engineers (USACE), U.S. Environmental Protection Agency (USEPA), U.S. Department of Agriculture (USDA), Natural Resources Conservation Service (NRCS), Federal Highway Administration (FHWA), and U.S. Fish and Wildlife Service (USFWS). The Action Plan, available online at http://www.epa.gov/owow/wetlands/science/hgm.html, outlines a strategy for developing Regional Guidebooks throughout the United States, provides guidelines and a specific set of tasks required to develop a Regional Guidebook under the HGM Approach, and solicits the cooperation and participation of Federal, State, and local agencies, academia, and the private sector.

This Regional Guidebook presents a general hydrogeomorphic classification of all wetlands that occur within alluvial valleys of eastern Texas. Detailed functional assessment criteria and models are presented for the most common of those wetland types. This report is organized in the following manner. Chapter 1 provides the background, objectives, and organization of the document. Chapter 2 provides a brief overview of the major components of the HGM Approach, including the procedures recommended for development and application of Regional Guidebooks. Chapter 3 characterizes the regional wetland subclasses in the alluvial 
valleys of East Texas. Chapter 4 discusses the wetland functions, assessment variables, and functional indices used in the guidebook from a generic perspective. Chapter 5 applies the assessment models to specific regional wetland subclasses and defines the relationship of assessment variables to reference data. Chapter 6 outlines the assessment protocol for conducting a functional assessment of regional wetland subclasses in alluvial valleys of East Texas. Appendix A presents preliminary project documentation and field sampling guidance. Field data forms are presented in Appendix B. Appendix C contains alternate field forms, and Appendix D contains demonstration printouts of calculation spreadsheets. Common and scientific names of plant species referenced in the text and data forms are listed in Appendix E. 


\section{Overview of the Hydrogeomorphic Approach}

\section{Development and Application Phases}

The HGM Approach consists of four components: (a) the HGM classification, (b) reference wetlands, (c) assessment variables and assessment models from which functional indices are derived, and (d) assessment protocols. The HGM Approach is conducted in two phases. An interdisciplinary Assessment Team of experts carries out the Development Phase of the HGM Approach. The task of the Assessment Team is to develop and integrate the classification, reference wetland information, assessment variables, models, and protocols of the HGM Approach into a Regional Guidebook (Figure 1).

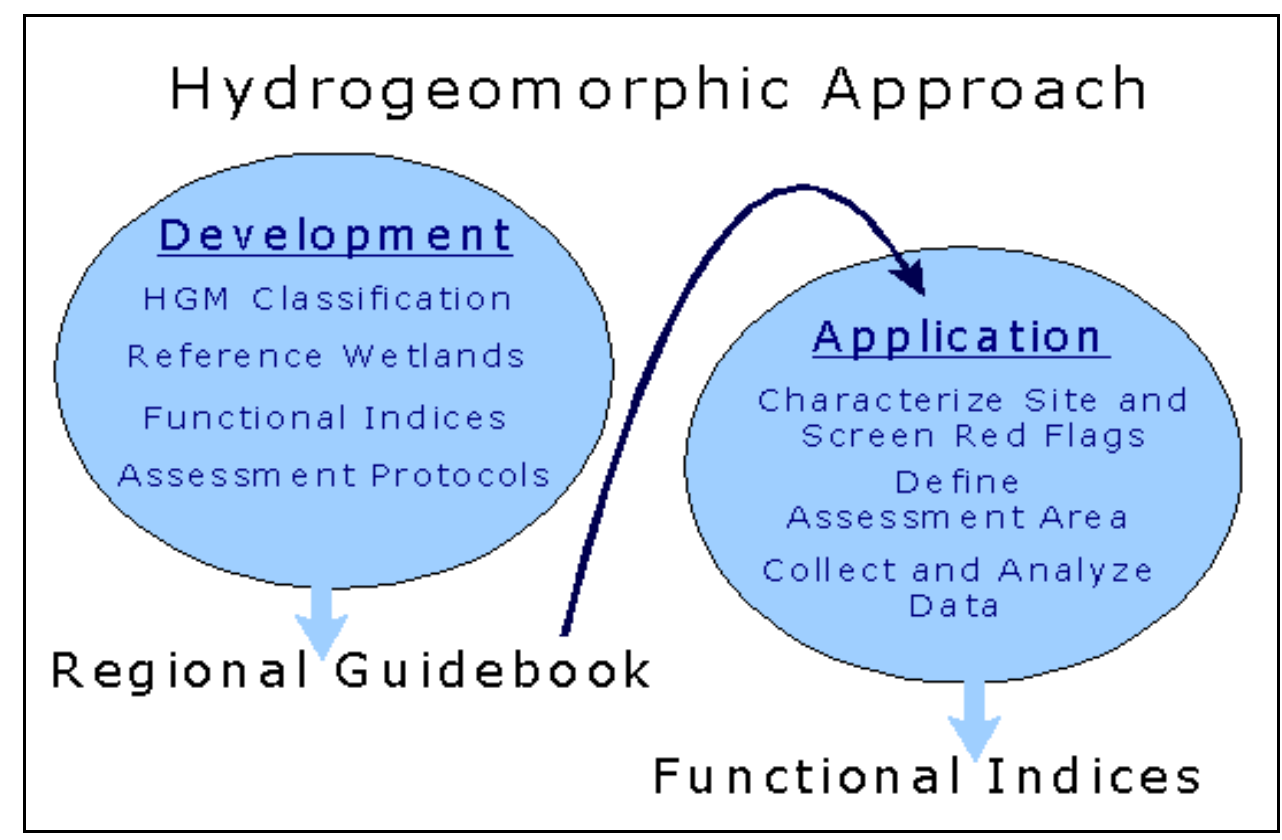

Figure 1. Development and Application Phases of the HGM Approach (from Ainslie et al. 1999).

In developing a Regional Guidebook, the team completes the tasks outlined in the National Action Plan (National Interagency Implementation Team 1996). After the team is organized and trained, its first task is to classify the wetlands of the region of interest into regional wetland subclasses using the principles and criteria of Hydrogeomorphic Classification (Brinson 1993a; Smith et al. 1995). Next, focusing on a specific regional wetland subclass, 
the team develops an ecological characterization or functional profile of the subclass. The Assessment Team then identifies the important wetland functions, conceptualizes assessment models, identifies assessment variables to represent the characteristics and processes that influence each function, and defines metrics for quantifying assessment variables. Next, reference wetlands are identified to represent the range of variability exhibited by the regional subclass, and field data are collected and used to calibrate assessment variables and indices resulting from assessment models. Finally, the team develops the assessment protocols necessary for regulators, managers, consultants, and other end users to apply the indices to the assessment of wetland functions in the context of 404 Permit review, restoration planning, and similar applications.

This guidebook was developed using a modification of the approach outlined above. A multi-agency workshop was convened in Nacogdoches, Texas in November, 2006 to discuss the potential to use an existing regional guidebook for wetlands in the West Gulf Coastal Plain Region of Arkansas (Klimas et al. 2005) as a template for this guidebook. That group, in effect, constituted the Assessment Team for this project, and as such selected the area of applicability, the wetland subclasses and functions to be assessed, and the form of the assessment models presented herein. In particular, the workshop participants directed that this guidebook should conform to the Arkansas template as much as possible. Subsequent pilot studies within the study area resulted in the elimination of several subclasses from the guidebook (the reasons are discussed in Chapter 3 ) and this guidebook incorporates a subsequent modification of the Arkansas guidebook that better captures hydrologic considerations. Otherwise, the two documents are consistent, although each is based on its own unique set of reference data collected within its area of applicability. The workshop participants were provided with reports detailing the results of the initial workshop, the results of the pilot study, and a review draft of this report, and their comments were incorporated to the extent that they were consistent with the directives of the original Nacogdoches planning meeting. Comments pertaining to policy matters were not incorporated, as that topic is beyond the scope of this guidebook.

During the Application Phase, the assessment variables, models, and protocols are used to assess wetland functions. This involves two steps. The first is to apply the assessment protocols outlined in the Regional Guidebook to complete the following tasks: 
- Define assessment objectives.

- Characterize the project site.

- Screen for red flags.

- Define the Wetland Assessment Area.

- Collect field data.

- Analyze field data.

The second step involves applying the results of the assessment at various decision-making points in the planning or permit review sequence, such as alternatives analysis, impact minimization, assessment of unavoidable impacts, determination of compensatory mitigation, design and monitoring of mitigation, comparison of wetland management alternatives or results, determination of restoration potential, or identification of acquisition or mitigation sites.

Each of the components of the HGM Approach that are developed and integrated into the Regional Guidebook is discussed briefly in the following paragraphs. More extensive treatment of these components can be found in Brinson (1993a, 1993b), Brinson et al. (1995, 1996, 1998), Hauer and Smith (1998), and Smith et al. (1995).

\section{Hydrogeomorphic Classification}

Wetland ecosystems share a number of common attributes including hydrophytic vegetation, hydric soils, and relatively long periods of inundation or saturation by water. In spite of these common attributes, wetlands occur in a variety of climatic, geologic, and physiographic settings and exhibit a wide range of physical, chemical, and biological characteristics and processes (Cowardin et al. 1979; Mitch and Gosselink 1993). The variability of wetlands makes it challenging to develop assessment methods that are both accurate (i.e., sensitive to significant changes in function) and practical (i.e., and that can be completed in the relatively short time frame normally available for conducting assessments). "Generic" wetland assessment methods have been developed to assess multiple wetland types throughout the United States. In general these methods can be applied quickly, but lack the resolution necessary to detect significant changes in function. One way to achieve an appropriate level of resolution within a limited time frame is to employ a wetland classification system structured to support functional assessment objectives (Smith et al. 1995). 
The HGM classification was developed specifically to accomplish this task (Brinson 1993a). It identifies groups of wetlands that function similarly using three criteria that fundamentally influence how wetlands function: geomorphic setting, water source, and hydrodynamics. Geomorphic setting refers to the position of the wetland in the landscape. Water source refers to the primary origin of the water that sustains wetland characteristics, such as precipitation, floodwater, or groundwater. Hydrodynamics refers to the level of energy with which water moves through the wetland, and the direction of water movement.

Based on these three criteria, any number of functional wetland groups can be identified at different spatial or temporal scales. For example, at a continental scale, Brinson (1993a, 1993b) identified five hydrogeomorphic wetland classes. These were later expanded to the seven classes described in Table 1 (Smith et al. 1995).

Table 1. Hydrogeomorphic wetland classes.

\begin{tabular}{|c|c|}
\hline $\begin{array}{l}\text { HGM } \\
\text { Wetland } \\
\text { Class }\end{array}$ & Definition \\
\hline Depression & $\begin{array}{l}\text { Depressional wetlands occur in topographic depressions (i.e., closed elevation contours) that } \\
\text { allow the accumulation of surface water. Depressional wetlands may have any combination } \\
\text { of inlets and outlets, or lack them completely. Potential water sources are precipitation, } \\
\text { overland flow, streams, or groundwater flow from adjacent uplands. The predominant } \\
\text { direction of flow is from the higher elevations toward the center of the depression. The } \\
\text { predominant hydrodynamics are vertical fluctuations that may occur over a range of time, } \\
\text { from a few days to many months. Depressional wetlands may lose water through } \\
\text { evapotranspiration, intermittent or perennial outlets, or recharge to groundwater. Prairie } \\
\text { potholes, playa lakes, and cypress domes are common examples of depressional wetlands. }\end{array}$ \\
\hline Tidal Fringe & $\begin{array}{l}\text { Tidal fringe wetlands occur along coasts and estuaries and are under the influence of sea } \\
\text { level. They intergrade landward with riverine wetlands where tidal current diminishes and } \\
\text { riverflow becomes the dominant water source. Additional water sources may be groundwater } \\
\text { discharge and precipitation. Because tidal fringe wetlands are frequently flooded and water } \\
\text { table elevations are controlled mainly by sea surface elevation, tidal fringe wetlands seldom } \\
\text { dry for significant periods. Tidal fringe wetlands lose water by tidal exchange, by overland flow } \\
\text { to tidal creek channels, and by evapotranspiration. Organic matter normally accumulates in } \\
\text { higher elevation marsh areas where flooding is less frequent and the wetlands are isolated } \\
\text { from shoreline wave erosion by intervening areas of low marsh or dunes. }\end{array}$ \\
\hline $\begin{array}{l}\text { Lacustrine } \\
\text { Fringe }\end{array}$ & $\begin{array}{l}\text { Lacustrine fringe wetlands are adjacent to lakes where the water elevation of the lake } \\
\text { maintains the water table in the wetland. Additional sources of water are precipitation and } \\
\text { groundwater discharge, the latter dominating where lacustrine fringe wetlands intergrade } \\
\text { with uplands or slope wetlands. Surface water flow is bidirectional. Lacustrine wetlands lose } \\
\text { water by evapotranspiration and by flow returning to the lake after flooding. Organic matter } \\
\text { may accumulate in areas sufficiently protected from shoreline wave erosion. Unimpounded } \\
\text { marshes bordering the Great Lakes are an example of lacustrine fringe wetlands. }\end{array}$ \\
\hline
\end{tabular}




\begin{tabular}{|c|c|}
\hline $\begin{array}{l}\text { HGM } \\
\text { Wetland } \\
\text { Class }\end{array}$ & Definition \\
\hline Slope & $\begin{array}{l}\text { Slope wetlands are found in association with the discharge of groundwater to the land } \\
\text { surface or on sites with saturated overland flow with no channel formation. They normally } \\
\text { occur on slightly to steeply sloping land. The predominant source of water is groundwater or } \\
\text { interflow discharging at the land surface. Precipitation is often a secondary contributing } \\
\text { source of water. Hydrodynamics are dominated by downslope unidirectional water flow. Slope } \\
\text { wetlands can occur in nearly flat landscapes if groundwater discharge is a dominant source } \\
\text { to the wetland surface. Slope wetlands lose water primarily by saturated subsurface flows, } \\
\text { surface flows, and evapotranspiration. They may develop channels, but the channels serve } \\
\text { only to convey water away from the slope wetland. Slope wetlands are distinguished from } \\
\text { depression wetlands by the lack of a closed topographic depression and the predominance } \\
\text { of the groundwater/interflow water source. Fens are a common example of slope wetlands. }\end{array}$ \\
\hline $\begin{array}{l}\text { Mineral Soil } \\
\text { Flats }\end{array}$ & $\begin{array}{l}\text { Mineral soil flats are most common on interfluves, extensive relic lake bottoms, or large } \\
\text { alluvial terraces where the main source of water is precipitation. They receive virtually no } \\
\text { groundwater discharge, which distinguishes them from depressions and slopes. Dominant } \\
\text { hydrodynamics are vertical fluctuations. Mineral soil flats lose water by evapotranspiration, } \\
\text { overland flow, and seepage to underlying groundwater. They are distinguished from flat non- } \\
\text { wetland areas by their poor vertical drainage due to impermeable layers (e.g., hardpans), } \\
\text { slow lateral drainage, and low hydraulic gradients. Pine flatwoods with hydric soils are an } \\
\text { example of mineral soil flat wetlands. }\end{array}$ \\
\hline $\begin{array}{l}\text { Organic Soil } \\
\text { Flats }\end{array}$ & $\begin{array}{l}\text { Organic soil flats, or extensive peatlands, differ from mineral soil flats in part because their } \\
\text { elevation and topography are controlled by vertical accretion of organic matter. They occur } \\
\text { commonly on flat interfluves, but may also be located where depressions have become filled } \\
\text { with peat to form a relatively large flat surface. Water source is dominated by precipitation, } \\
\text { while water loss is by overland flow and seepage to underlying groundwater. They occur in } \\
\text { relatively humid climates. Raised bogs share many of these characteristics but may be } \\
\text { considered a separate class because of their convex upward form and distinct edaphic } \\
\text { conditions for plants. Portions of the Everglades and northern Minnesota peatlands are } \\
\text { examples of organic soil flat wetlands. }\end{array}$ \\
\hline Riverine & $\begin{array}{l}\text { Riverine wetlands occur in floodplains and riparian corridors in association with stream } \\
\text { channels. Dominant water sources are overbank or backwater flow from the channel. } \\
\text { Additional sources may be interflow, overland flow from adjacent uplands, tributary inflow, } \\
\text { and precipitation. When overbank flow occurs, surface flows down the floodplain may } \\
\text { dominate hydrodynamics. In headwaters, riverine wetlands often intergrade with slope, } \\
\text { depressional, poorly drained flat wetlands, or uplands as the channel (bed) and bank } \\
\text { disappear. Perennial flow is not required. Riverine wetlands lose surface water via the return } \\
\text { of floodwater to the channel after flooding and through surface flow to the channel during } \\
\text { rainfall events. They lose subsurface water by discharge to the channel, movement to deeper } \\
\text { groundwater, and evapotranspiration. Bottomland hardwood forests on floodplains are } \\
\text { examples of riverine wetlands. }\end{array}$ \\
\hline
\end{tabular}

Generally, the level of variability encompassed by wetlands at the continental scale of hydrogeomorphic classification is too great to allow development of assessment indices that can be applied rapidly and still retain the level of sensitivity necessary to detect changes in function at a level of resolution appropriate to the 404 permit review. In order to reduce both inter- and intraregional variability, the three classification criteria must be applied at a smaller, regional geographic scale; thus creating 
regional wetland subclasses. In many parts of the country, existing wetland classifications can serve as a starting point for identifying these regional subclasses (e.g., Golet and Larson 1974; Stewart and Kantrud 1971; Wharton et al. 1982). Regional subclasses, like the continental scale wetland classes, are distinguished on the basis of geomorphic setting, water source, and hydrodynamics. Examples of potential regional subclasses are shown in Table 2. In addition, certain ecosystem or landscape characteristics may be useful for distinguishing regional subclasses. For example, depression subclasses might be based on water source (i.e., groundwater versus surface water) or the degree of connection between the wetland and other surface waters (i.e., the flow of surface water in or out of the depression through defined channels). Tidal fringe subclasses might be based on salinity gradients (Shafer and Yozzo 1998). Slope subclasses might be based on the degree of slope or landscape position. Riverine subclasses might be based on position in the watershed, stream order, watershed size, channel gradient, or floodplain width. Regional Guidebooks include a thorough characterization of the regional wetland subclass in terms of geomorphic setting, water sources, hydrodynamics, vegetation, soil, and other features that were taken into consideration during the classification process.

Table 2. Potential regional wetland subclasses in relation to classification criteria.

\begin{tabular}{|l|l|l|l|l|}
\hline \multicolumn{3}{|c|}{ Classification Criteria } & \multicolumn{2}{l|}{ Potential Regional Wetland Subclasses } \\
\hline $\begin{array}{l}\text { Geomorphic } \\
\text { Setting }\end{array}$ & $\begin{array}{l}\text { Dominant Water } \\
\text { Source }\end{array}$ & $\begin{array}{l}\text { Dominant } \\
\text { Hydrodynamics }\end{array}$ & Eastern USA & $\begin{array}{l}\text { Western } \\
\text { USA/Alaska }\end{array}$ \\
\hline Depression & $\begin{array}{l}\text { Groundwater or } \\
\text { interflow }\end{array}$ & Vertical & $\begin{array}{l}\text { Prairie pothole } \\
\text { marshes, Carolina } \\
\text { bays }\end{array}$ & $\begin{array}{l}\text { California vernal } \\
\text { pools }\end{array}$ \\
\hline $\begin{array}{l}\text { Fringe } \\
\text { (tidal) }\end{array}$ & Ocean & $\begin{array}{l}\text { Bidirectional, } \\
\text { horizontal }\end{array}$ & $\begin{array}{l}\text { Chesapeake Bay } \\
\text { and Gulf of Mexico } \\
\text { tidal marshes }\end{array}$ & $\begin{array}{l}\text { San Francisco Bay } \\
\text { marshes }\end{array}$ \\
\hline Fringe (lacustrine) & Lake & $\begin{array}{l}\text { Bidirectional, } \\
\text { horizontal }\end{array}$ & $\begin{array}{l}\text { Great Lakes } \\
\text { marshes }\end{array}$ & $\begin{array}{l}\text { Flathead Lake } \\
\text { marshes }\end{array}$ \\
\hline Slope & Groundwater & $\begin{array}{l}\text { Unidirectional, } \\
\text { horizontal }\end{array}$ & Fens & Avalanche chutes \\
\hline $\begin{array}{l}\text { Flat } \\
\text { (mineral soil) }\end{array}$ & Precipitation & Vertical & Wet pine flatwoods & Large playas \\
\hline $\begin{array}{l}\text { Flat } \\
\text { (organic soil) }\end{array}$ & Precipitation & Vertical & $\begin{array}{l}\text { Peat bogs; portions } \\
\text { of Everglades }\end{array}$ & $\begin{array}{l}\text { Peatlands over } \\
\text { permafrost }\end{array}$ \\
\hline $\begin{array}{l}\text { Riverine } \\
\text { Adapted from Smith et al. 1995, Rheinhardt et al. 1997. } \\
\text { Overbank flow from }\end{array}$ & $\begin{array}{l}\text { Unidirectional, } \\
\text { horizontal }\end{array}$ & $\begin{array}{l}\text { Bottomland } \\
\text { hardwood forests }\end{array}$ & Riparian wetlands \\
\hline
\end{tabular}




\section{Reference Wetlands}

Reference wetlands are the wetland sites selected to represent the range of variability that occurs in a regional wetland subclass as a result of natural processes and disturbance (e.g., succession, channel migration, fire, erosion, and sedimentation) as well as anthropogenic alteration (e.g., grazing, timber harvest, clearing). The reference domain is the geographic area occupied by the reference wetlands (Smith et al. 1995; Smith 2001). Ideally, the geographic extent of the reference domain will mirror the geographic area encompassed by the regional wetland subclass; however, this is not always possible due to time and resource constraints.

Reference wetlands serve several purposes. First, they establish a basis for defining what constitutes a characteristic and sustainable level of function across the suite of functions selected for a regional wetland subclass. Second, reference wetlands establish the range and variability of conditions exhibited by assessment variables, and provide the data necessary for calibrating assessment variables and models. Finally, they provide a concrete physical representation of wetland ecosystems that can be observed and remeasured as needed.

Reference standard wetlands are the subset of reference wetlands that perform the suite of functions selected for the regional subclass at a level that is characteristic of the least altered wetland sites in the least altered landscapes. Table 3 outlines the terms used by the HGM Approach in the context of reference wetlands.

Table 3. Reference wetland terms and definitions.

\begin{tabular}{|l|l|}
\hline Term & Definition \\
\hline Reference Domain & $\begin{array}{l}\text { The geographic area from which reference wetlands representing the } \\
\text { regional wetland subclass are selected. }\end{array}$ \\
\hline Reference Wetlands & $\begin{array}{l}\text { A group of wetlands that encompass the known range of variability in the } \\
\text { regional wetland subclass resulting from natural processes and human } \\
\text { alteration. }\end{array}$ \\
\hline Reference Standard Wetlands & $\begin{array}{l}\text { The subset of reference wetlands that perform a representative suite of } \\
\text { functions at a level that is both sustainable and characteristic of the least } \\
\text { human altered wetland sites in the least human altered landscapes. By } \\
\text { definition, the functional capacity index for all functions in a reference } \\
\text { standard wetland is 1.0. }\end{array}$ \\
\hline $\begin{array}{l}\text { Reference Standard Wetland } \\
\text { Variable Condition }\end{array}$ & $\begin{array}{l}\text { The range of conditions exhibited by assessment variables in reference } \\
\text { standard wetlands. By definition, reference standard conditions receive a } \\
\text { variable subindex score of 1.0. }\end{array}$ \\
\hline
\end{tabular}




\section{Assessment Models and Functional Indices}

In the HGM Approach, an assessment model is a simple representation of a function performed by a wetland ecosystem. The assessment model defines the relationship between the characteristics and processes of the wetland ecosystem and the surrounding landscape that influence the functional capacity of a wetland ecosystem. Characteristics and processes are represented in the assessment model by assessment variables. Functional capacity is the ability of a wetland to perform a specific function relative to the ability of reference standard wetlands to perform the same function. Application of assessment models results in a Functional Capacity Index (FCI) ranging from 0.0 to 1.0. Wetlands with an FCI of 1.0 perform the assessed function at a level that is characteristic of reference standard wetlands. A lower FCI indicates that the wetland is performing a function at a level below that characteristic of reference standard wetlands.

For example, the following equation shows an assessment model that could be used to assess the capacity of a wetland to detain floodwater.

$$
\mathrm{FCI}=\mathrm{V}_{\mathrm{FREQ}} \times\left[\frac{\left(\mathrm{V}_{\mathrm{LOG}}+\mathrm{V}_{\mathrm{GVC}}+\mathrm{V}_{\mathrm{SSD}}+\mathrm{V}_{\mathrm{TDEN}}\right)}{4}\right]
$$

The assessment model has five assessment variables: frequency of flooding $\left(\mathrm{V}_{\mathrm{FREQ}}\right)$, which represents the frequency at which a wetland is inundated by overbank flooding, and the assessment variables of log density ( $\left.\mathrm{V}_{\mathrm{LOG}}\right)$, ground vegetation cover $\left(\mathrm{V}_{\mathrm{GVC}}\right)$, shrub and sapling density ( $\left.\mathrm{V}_{\mathrm{SSD}}\right)$, and tree stem density ( $\mathrm{V}_{\text {TDEN }}$ ) that together represent resistance to flow of floodwater through the wetland.

The state or condition of an assessment variable is indicated by the value of the metric used to assess a variable, and the metric used is normally one commonly used in ecological studies. For example, tree basal area $\left(\mathrm{m}^{2} / \mathrm{ha}\right)$ is the metric used to assess tree biomass in a wetland, with larger numbers usually indicating greater stand maturity and increasing functionality for several different wetland functions where tree biomass is an important consideration.

Based on the metric value, an assessment variable is assigned a variable subindex. When the metric value of an assessment variable is within the range of conditions exhibited by reference standard wetlands, a variable 
subindex of 1.0 is assigned. As the metric value deflects, in either direction, from the reference standard condition, the variable subindex decreases based on a defined relationship between metric values and functional capacity. Thus, as the metric value deviates from the conditions documented in reference standard wetlands, it receives a progressively lower subindex reflecting the decreased functional capacity of the wetland. Figure 2 illustrates the relationship between metric values of tree density $\left(\mathrm{V}_{\text {TDEN }}\right)$ and the variable subindex for an

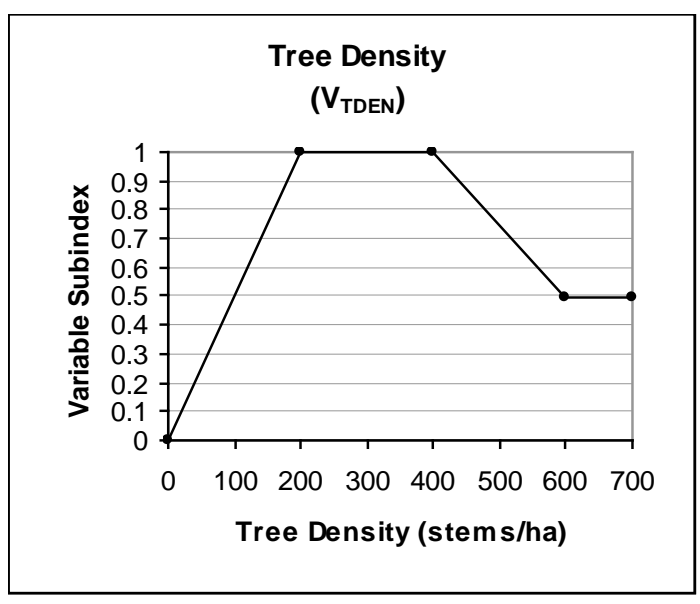

Figure 2. Example subindex graph for the tree density $\left(V_{\text {TDEN }}\right)$ assessment variable for a particular wetland subclass. example wetland subclass. As shown in the graph, tree densities of 200 to 400 stems/ ha represent reference standard conditions, based on field studies, and a variable subindex of 1.0 is assigned for assessment models where tree density is a component. Where tree densities are higher or lower than those found in reference standard conditions, a lesser variable subindex value is assigned.

\section{Assessment Protocol}

All of the steps described in the preceding sections concern development of the assessment tools and the rationale used to produce this Regional Guidebook. Although users of the guidebook should be familiar with this process, their primary concern will be the protocol for application of the assessment procedures. The assessment protocol is a defined set of tasks, along with specific instructions, that allows resource professionals to assess the functions of a particular wetland area using the assessment models and functional indices in the Regional Guidebook. The first task includes characterizing the wetland ecosystem and the surrounding landscape, describing the proposed project and its potential impacts, and identifying the wetland areas to be assessed. The second task is collecting the field data for assessment variables. The final task is an analysis that involves calculation of functional indices. These steps are described in detail in Chapter 6, and the required data forms and spreadsheets are provided in Appendices A through D. 


\section{Characterization of Wetland Subclasses in the Alluvial Valleys of East Texas}

\section{Reference Domain}

The information in this guidebook applies to forested wetlands in alluvial valleys of the South Central Plains Ecoregion of East Texas, which is designated as U. S. Environmental Protection Agency (EPA) Level III Ecoregion 35. The largest alluvial valleys in the region are mapped as EPA Level IV Ecoregion 35b (Floodplains and Low Terraces), but this guidebook also is intended to apply to tributary valleys too small to be included in that category, as well as a small portion of Level IV Ecoregion 35c (Pleistocene Fluvial Terraces) that occurs along the Sulphur River (Figure 3). The forested wetlands of the Red River in EPA Level IV Ecoregions 35c and 35g are not included. These wetlands are covered in the HGM guidebook for the West Gulf Coastal Plain Region of Arkansas (Klimas et al. 2005). The reference domain generally corresponds to the area traditionally designated as the Pineywoods Ecoregion of East Texas, and will be referred to by that name in this document.

The following is an overview of the physical and biotic conditions within the reference domain that influence the characteristics and functions of wetlands. Descriptions of the wetland classes and subclasses that occur in the region and guidelines for recognizing them in the field are presented as the final section of this chapter.

\section{Climate}

East Texas has high humidity, hot summer temperatures and cool winter temperatures indicative of the humid, sub-tropic eco-climatic zone (Bailey 1995). Average daily maximum temperatures range from a high of about $94^{\circ} \mathrm{F}$ in August to about $55^{\circ} \mathrm{F}$ in J anuary (Natural Resources Conservation Services (NRCS 1995). Average daily minimum temperatures range from about $72^{\circ} \mathrm{F}$ in J uly to about $39^{\circ} \mathrm{F}$ in J anuary. Average annual rainfall is between 46 and $53 \mathrm{in}$. The monthly distribution of rainfall is generally even. Mild droughts occur usually during late summer to early fall. Slightly greater amounts of rainfall occur during the winter and early spring. Tropical storms periodically enter from the Gulf of Mexico during the summer and fall resulting in short periods of heavy rain and high winds. Ice storms occur infrequently in the northern part of the region. 


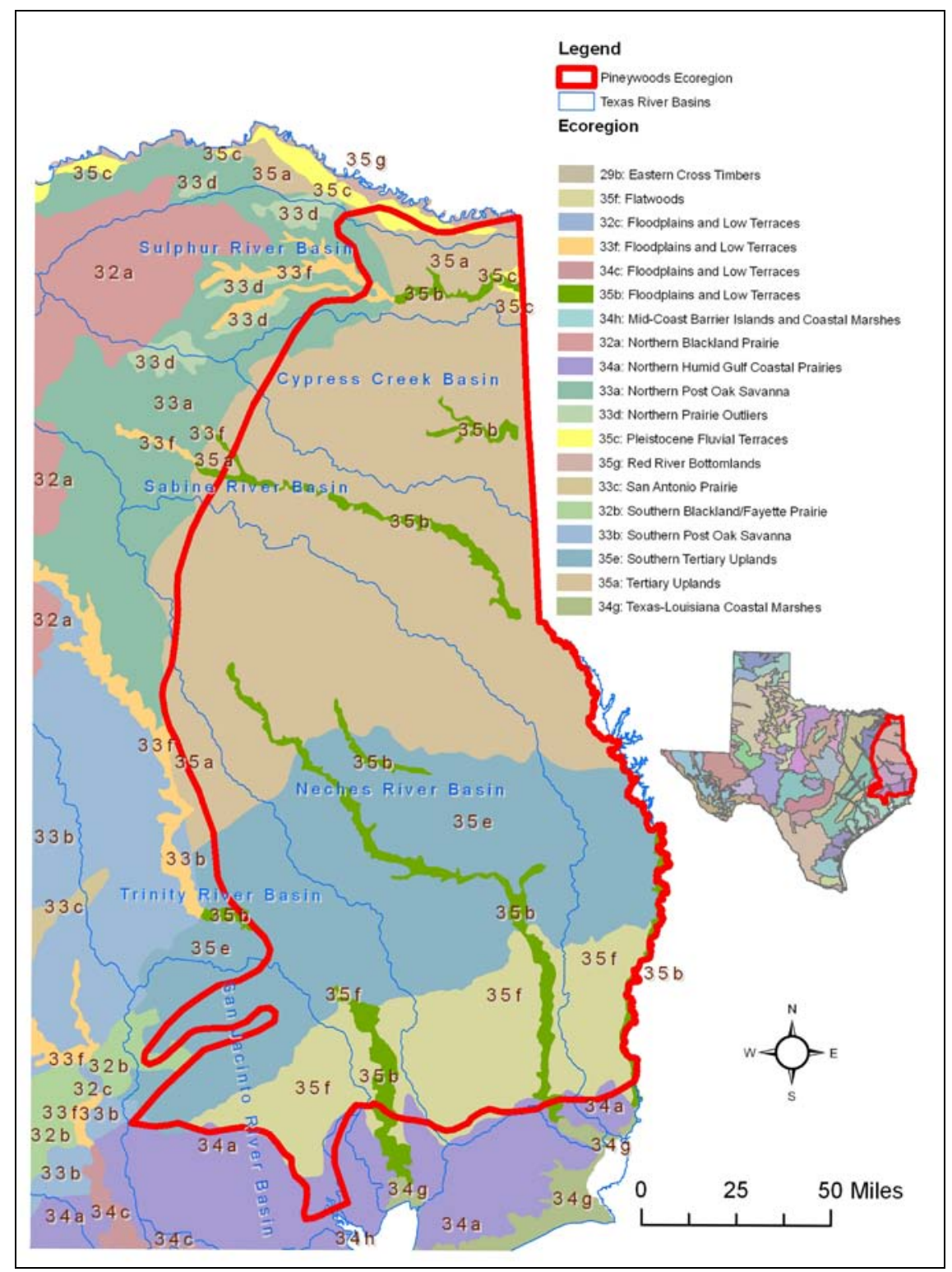

Figure 3. Ecoregions of East Texas (Source: U.S. Environmental Protection Agency (USEPA) 2009).

\section{Drainage Systems and Hydrology}

From north to south, the major river basins that occur partly or wholly within the reference domain are the Sulphur River Basin, Cypress Creek Basin, Sabine River Basin, Neches River Basin, and the Trinity River Basin (Figure 4). The Sulphur River and Cypress Creek Basins drain generally from west to east. The general drainage for the other basins is from the northwest to southeast. 


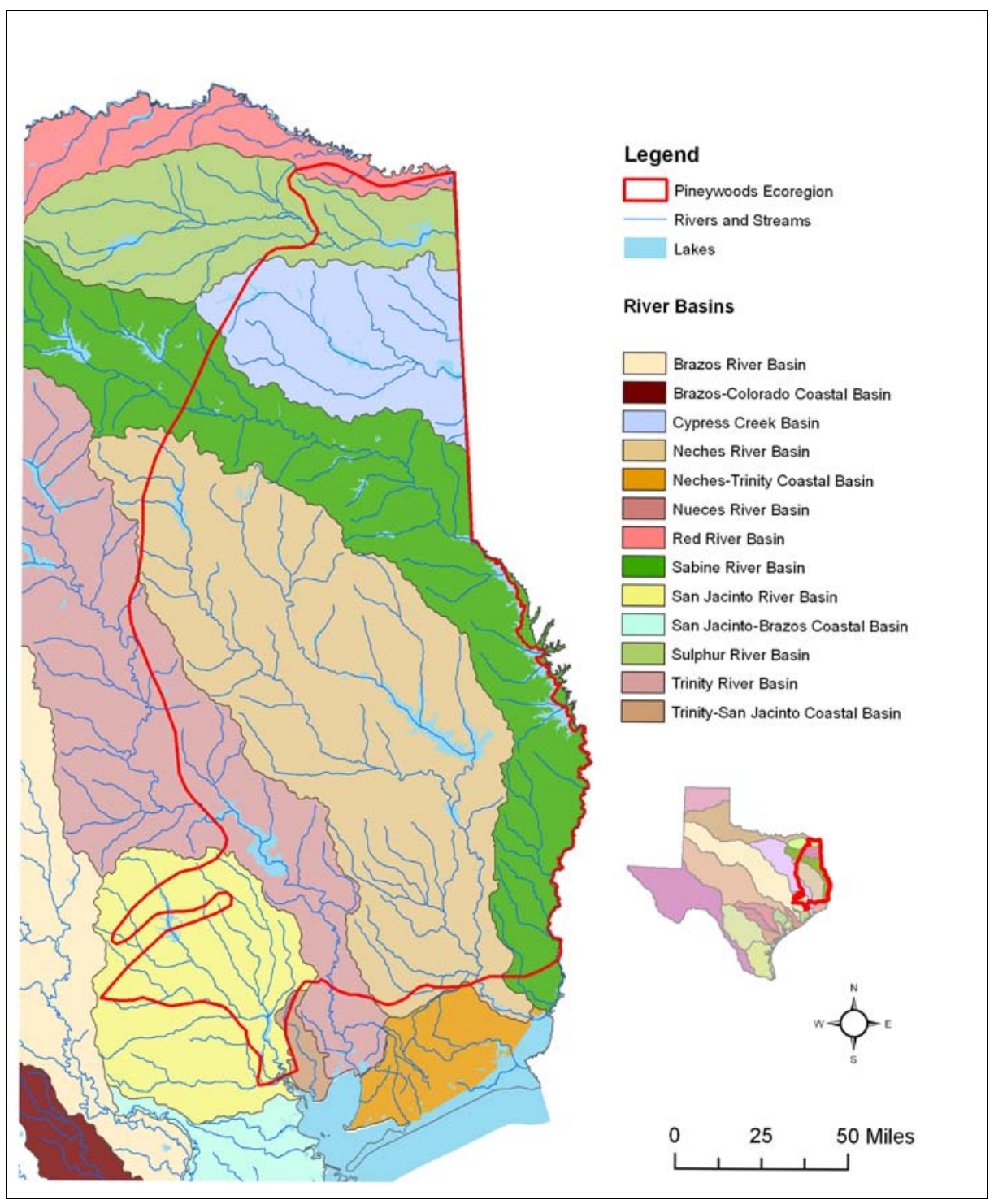

Figure 4. Major drainage basins of East Texas (Source: Texas Parks and Wildlife Department 2009).

The Sulphur River Basin drains 11 counties in northeast Texas with a drainage area of 3558 square miles (Texas Commission on Environmental Quality (TCEQ) 2004). The Sulphur River originates in Fannin County and flows eastward into Wright Patman Lake, a multipurpose reservoir operated by the Corps of Engineers. From the reservoir, the Sulphur River continues to flow eastward until it enters the Red River in Arkansas. In the Sulphur River Basin, the reference domain includes the forested wetlands in or near floodplains within Cass and Bowie Counties.

The Cypress Creek Basin originates in Hopkins County and drains an area of 2812 square miles. Big Cypress Bayou flows from Lake Bob Sandlin 
Reservoir in a southeasterly direction until it reaches Lake O' the Pines Reservoir. The reference domain in this basin is located primarily in Marion County and Harrison County beginning below Lake O' the Pines until Big Cypress Bayou flows into Caddo Lake. This includes the floodplains of the Big Cypress Bayou tributaries of Little Cypress Bayou and Black Cypress Bayou. Caddo Lake drains into Twelve Mile Bayou and then into the Red River.

The Sabine River Basin drains an area of 9756 square miles located in Louisiana and Texas. The majority of the drainage area lies in Texas. The Sabine River flows from Lake Tawakoni Reservoir in a southeasterly direction. The reference domain begins where the river leaves Van Zandt and Rains Counties and begins forming the boundary between Wood and Smith Counties. The forested wetlands adjacent to Lake Fork Creek below Lake Fork Reservoir are included in the reference domain. Lake Fork Creek flows in to the Sabine River east of Mineola, TX. The Sabine River continues to flow in a southeast direction until it enters Shelby County where the river turns south and enters Toledo Bend Reservoir. Below Toledo Bend Reservoir, the reference domain associated with the Sabine River continues until just north of Orange, Orange County, TX. The Sabine River eventually flows into Sabine Lake, a saltwater estuary that drains through Sabine Pass into the Gulf of Mexico.

In the Neches River Basin, the reference domain is primarily associated with the Neches and Angelina Rivers. The Neches River Basin drains 10,011 square miles. The Neches River begins in Van Zandt County and flows in a southeastern direction into Lake Palestine Reservoir located south of Tyler, TX. Below Lake Palestine, the Neches River continues in a southeastern direction until it flows into B. A. Steinhagen Lake Reservoir. Below B. A. Steinhagen Lake, the Neches River flows through the National Park Service, Big Thicket National Preserve. The Neches River passes through Beaumont, TX draining into Sabine Lake. The Angelina River begins in Rusk County flowing in a southeast direction until it empties into Sam Rayburn Reservoir. Below Sam Rayburn Reservoir, the Angelina River drains into B. A. Steinhagen Lake where it contributes flow to the Neches River.

The Trinity River Basin begins in north central Texas near the Dallas/ Fort Worth metropolitan area and ends at Trinity Bay in southeastern Texas on the Gulf Coast in Chambers County. The basin drains an area of almost 
18000 square miles. Only a small portion of the Trinity River Basin in southeastern Texas is included in the reference domain. This includes the forested wetlands in or near the floodplain of the Trinity River north of Lake Livingston Reservoir in Walker and Trinity Counties. Also, the reference domain includes the forested wetlands adjacent to the Trinity River below Lake Livingston until the river flows into Trinity Bay.

Additional ecosystems characteristic of EPA Ecoregion Level IV 35b include those found in the San J acinto River Basin and the Attoyac Bayou in the Neches River Basin. The East and West Fork of the San J acinto River are located in the southern portion of the Pineywoods in San J acinto, Liberty, and Montgomery Counties. Both forks flow into Lake Houston Reservoir. Attoyac Bayou forms the boundary between Nacogdoches and San Augustine Counties in the central portion of the Pineywoods. Attoyac Bayou flows into Sam Rayburn Reservoir.

Groundwater in the Pineywoods Ecoregion is associated with two major and four minor aquifers (Texas Water Development Board (TWDB) 2007, Figures 5 and 6). The major aquifers are the Gulf Coast Aquifer and the Carrizo-Wilcox Aquifer. The Gulf Coast Aquifer is located in the southern Pineywood counties of Walker, Montgomery, Harris, San J acinto, Liberty, Polk, Hardin, Tyler, J asper, and Newton. The Carrizo-Wilcox Aquifer contributes groundwater to the central and northern Pineywoods. The minor aquifers are the Sparta Aquifer and the Queen City Aquifer. These aquifers are narrow bands through the central and northern portions of the Pineywoods.

Surface water hydrology of the forested wetlands in the reference domain is similar to that observed in floodplain forests elsewhere in the southern United States (Kellison et al. 1998). Overbank flooding occurs in the winter and spring in most years, and occasionally during the summer, especially after tropical storms. Depressions pond water after rainfall or retain water for long periods after overbank floodwater recedes. The water table rises to near the soil surface after leaf senescence during the fall and remains high until evapotranspiration begins to increase in the spring. 


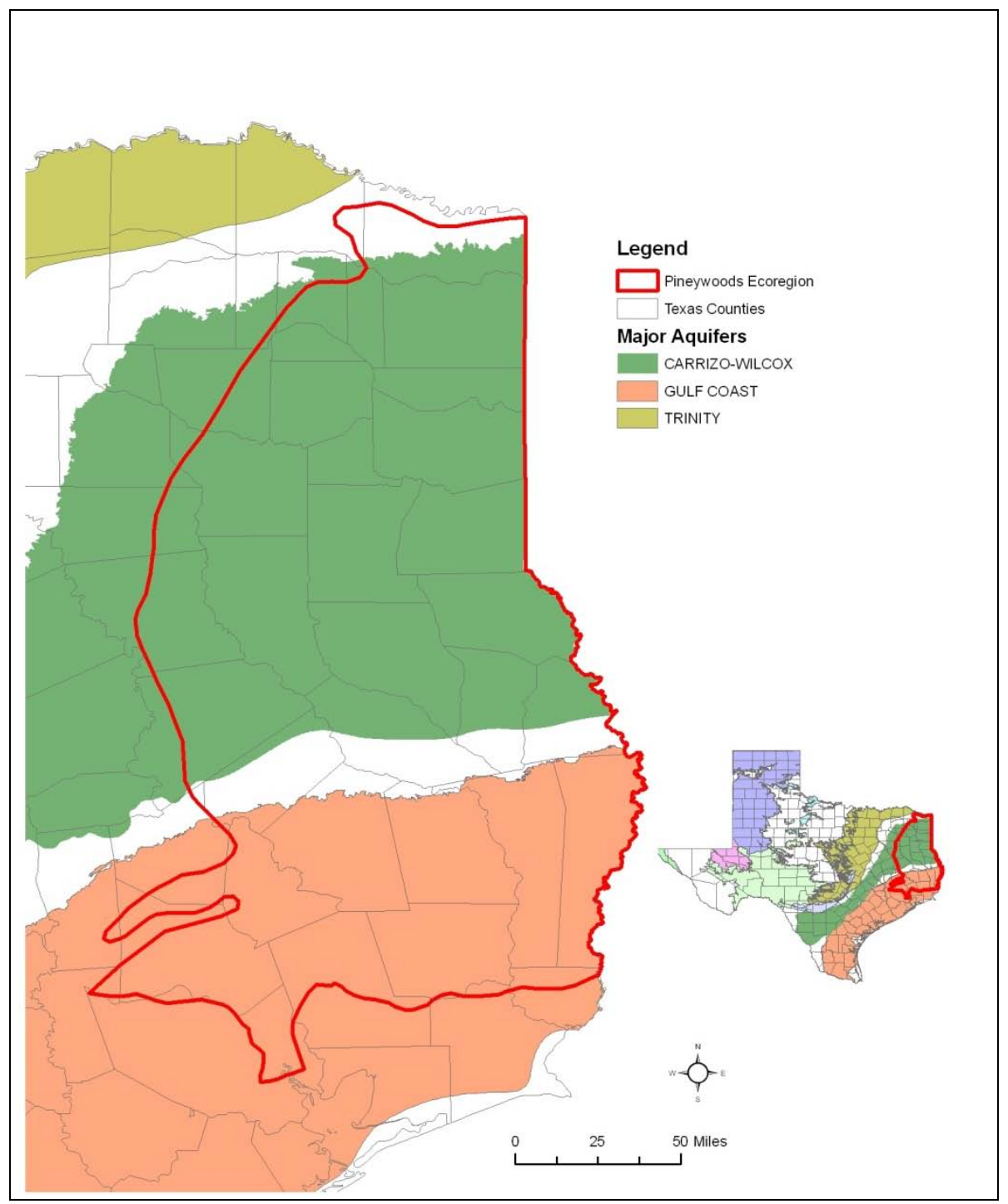

Figure 5. Major aquifers of East Texas (Source: TWDB 2009).

The hydrology of forested wetlands in the reference domain has been variously affected by human activities. Each river basin contains at least one reservoir that influences the timing, frequency, depth and duration of flooding and related geomorphic processes, although those changes may not extend great distances downstream (Phillips 2003). Transportation corridors, utility rights-of-way, oil and gas exploration, and channelization also affect hydrology by altering runoff patterns, retention time, and flow routes. 


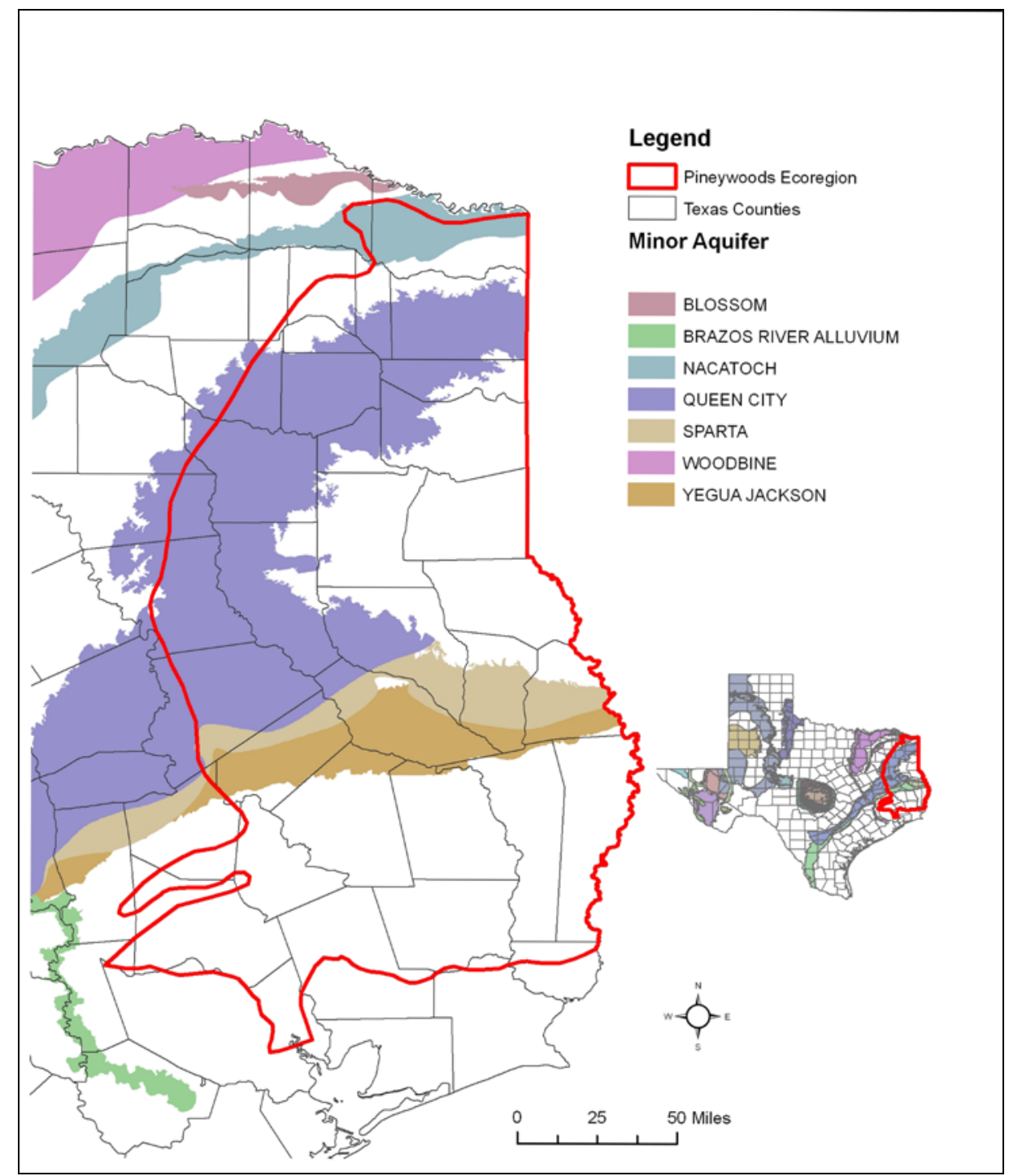

Figure 6. Minor aquifers of East Texas (Source: TWDB 2009).

\section{Geology and Geomorphology}

At the beginning of the Tertiary Period, about 65 million years ago, the area that is now the Pineywoods region was covered by the Gulf of Mexico (Spearing 1991). As the Gulf slowly retreated, it exposed a series of coastparallel sedimentary deposits in southeastern Texas (Dumble 1918). The sediments and sedimentary beds include sands, sandstones, clays, shales and limestone; they gently slope toward the Gulf of Mexico, with the youngest deposits being those furthest south (Pirkle and Yoho 1977).

The deposits that make up the rolling hills of the northern Pineywoods were laid down during the Eocene Epoch and include the Claiborne Group (Cook Mountain, Sparta, Weches, Queen City, and Reklaw, Yegua 
Formations)(Bureau of Economic Geology 1992). This group consists of ironstone concretions and materials ranging from sands to clays, including glauconite clay, a green, iron-rich clay formed in shallow marine water where sedimentation was slow (Spearing 1991). Below the Eocene sediments is the Catahoula Formation, which was deposited during the Oligocene Epoch; to the south is the Miocene-age Fleming Formation, then the Pliocene Willis Formation. The flat topography of the Lissie and Beaumont Formations of the Pleistocene Epoch form distinct coastal terraces in the extreme southern portion of the Pineywoods region.

The streams that cut across these major formations erode and redeposit the various marine and coastal sediments as characteristic meander-belt features (Van Kley 2006). As a result, the floodplains and low terraces of the reference domain consist of recent (Holocene) and late Pleistocene deposits of sand, silt, and clay alluvium. Geomorphic features include point bars, natural levees, and backswamps (Figure 7). The following discussion of the origins and characteristics of those features is taken largely from Klimas et al. (2005).

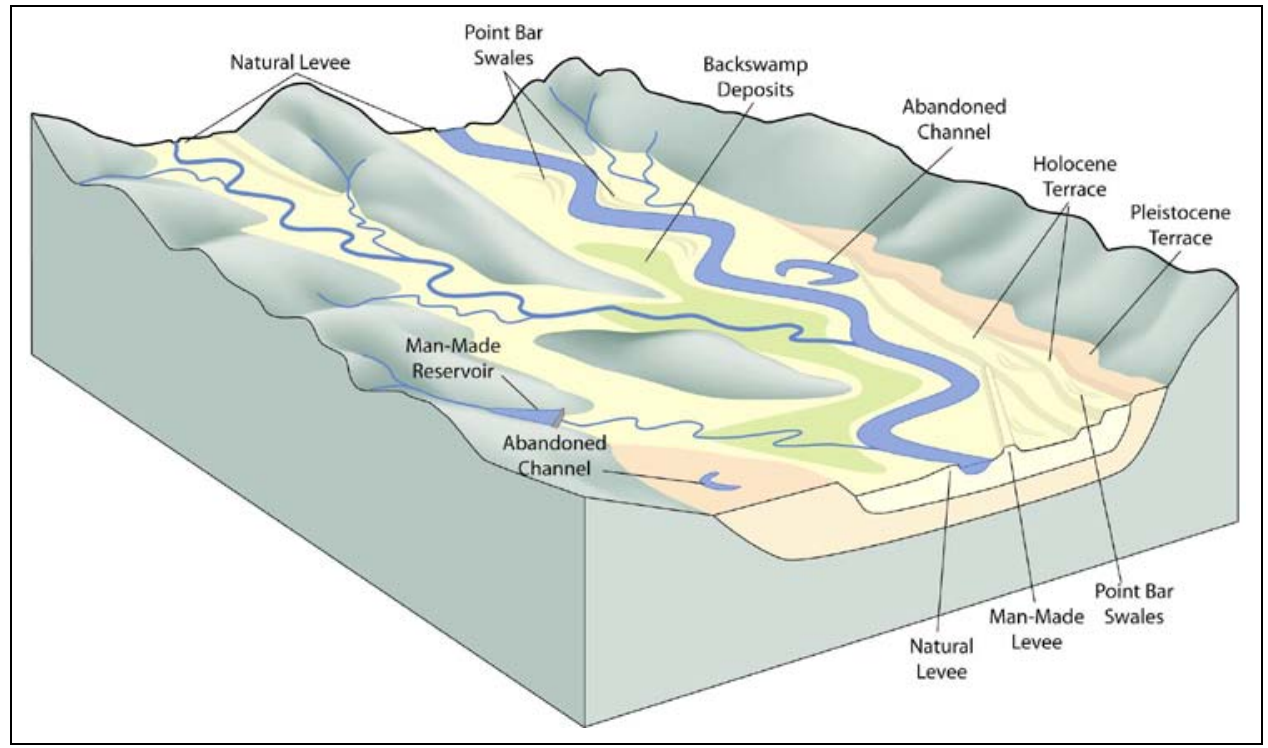

Figure 7. Typical form and locations of geomorphic and man-made features within river valleys.

\section{Point bars}

Point bars form on the inside bend of stream channels as they migrate laterally and downstream, eroding the opposite bank and depositing material on the inside of the bend. The deposited material accumulates as a series of sand ridges and intervening swales. The swales usually become 
lined or filled with silty or clayey sediments left by floodwaters trapped behind the ridges, but the overall texture of point bar deposits tends to be relatively coarse sands or gravels. The typical ridge and swale topography of point bar deposits is sometimes referred to as a meander scroll or point bar complex.

\section{Backswamps}

Backswamps are flat, poorly drained areas bounded by higher alluvial features. Because sedimentation rates are highest along the active stream channel, meander belts tend to develop into an alluvial ridge, where elevations are higher than the adjacent floodplain. The result is that local drainage is directed away from the major stream channel, and the areas between meander belts become basins (backswamps) that collect runoff, pool floodwaters, and accumulate fine sediments. They characteristically have clay substrates and are incompletely drained by small streams and interconnected swales. They may include large areas that do not fully drain through channel systems but remain ponded well into the growing season. Where backswamps are bounded on one side by the valley wall or terraces, they are referred to as rimswamps, which receive drainage from uplands and sometimes groundwater discharge from valley walls.

\section{Abandoned channels}

These features are the result of cutoffs, where a stream abandons a channel segment either because flood flows have scoured out a point bar swale and created a new main channel (chute cutoff), or because migrating bendways intersect and channel flow moves through the neck (neck cutoff). Chute cutoffs tend to be relatively small and to fill rapidly with sediment. They do not usually form lakes, but may persist as large depressions. The typical sequence of events following a neck cutoff (which is much more common than a chute cutoff) is that the upper and lower ends of the abandoned channel segment fill with sediment, leaving an open-water oxbow lake in the remainder of the channel. Where an abandoned stream channel incorporates two or more meander loops, it is referred to as an abandoned course.

\section{Natural levees}

A natural levee forms where overbank flows result in deposition of relatively coarse sediments (sand and silt) adjacent to the stream channel. 
The material is deposited as a continuous sheet that thins with distance from the stream, resulting in a low, wedge-shaped ridge paralleling the channel and blanketing areas of point bar and backswamp. Where channels have changed course, natural levee ridges are left behind on the banks of oxbow lakes or as low ridges within the floodplain.

\section{Terraces}

Alluvial terraces are former floodplains abandoned by a stream when it passed through a period of bed erosion and established a new floodplain at a lower level. The abandoned floodplain surface is composed of the sediments and landforms described in the preceding text, and frequently sustains wetlands in the relic swales, channels, and backswamps. However, the wetland character is maintained primarily by precipitation rather than flooding. On very old terraces, the alluvial features may be so subdued from erosion that the surface appears flat. Where internal drainage is well developed, the terrace becomes dissected and may not sustain any wetland environments.

\section{Soils}

The major soil associations of the alluvial terraces and floodplains within the reference domain are identified in Table 4 . They typically are deep, somewhat poorly drained to moderately well-drained soils with slow permeability. Descriptions of the individual soil series that occur within each association can be found at http://soils.usda.gov/technical/classification/scfile/index.html.

\section{Vegetation}

Forests cover about 57 percent of the land area, or 12.1 million acres, in East Texas (Rudis et al. 2003); most of this forestland is located in the Pineywoods region. Softwood forest types cover about 5.2 million acres with almost half of this acreage in managed pine plantations. Bottomland hardwoods cover about 2 million acres and represent the principal forest type of the reference domain. The vegetation classification for the reference domain in each of the river basins is Willow Oak-Water OakBlackgum Forest (McMahan et al. 1984, Figure 8). In addition to the abundant willow oak (Quercus phellos), water oak (Q. nigra), and black gum (Nyssa sylvatica), common plants observed in the vegetation type include overcup oak (Q. lyrata), cow oak (Q. michauxii), cherrybark oak 
Table 4. Characteristics of the principal soils of alluvial valleys in East Texas. (Source: USDA Natural Resources Conservation Service online data accessed January 2009 http://soils.usda.gov/technical/classification/scfile/index.html).

\begin{tabular}{|c|c|c|c|c|}
\hline River Basin & Map Unit & Orders & Characteristics & Principal Landscape Setting \\
\hline $\begin{array}{l}\text { Sulphur River } \\
\text { Basin } \\
\text { ecoregion 35b }\end{array}$ & $\begin{array}{l}\text { Texark-Kaufman- } \\
\text { Gladewater }\end{array}$ & Vertisol & $\begin{array}{l}\text { Very deep, somewhat poorly drained, } \\
\text { very slowly permeable clay soils that } \\
\text { formed in clayey alluvium. }\end{array}$ & $\begin{array}{l}\text { On the floodplains of streams draining the } \\
\text { Blackland Prairies. }\end{array}$ \\
\hline \multirow{2}{*}{$\begin{array}{l}\text { Sulphur River } \\
\text { Basin } \\
\text { ecoregion 35c }\end{array}$} & Woodtell-Freestone & Alfisol & $\begin{array}{l}\text { Deep, well to moderately well drained, } \\
\text { slowly to very slowly permeable soils. }\end{array}$ & $\begin{array}{l}\text { On Pleistocene terraces and remnants of } \\
\text { terraces on upland positions. }\end{array}$ \\
\hline & $\begin{array}{l}\text { Woodtell-Sawyer- } \\
\text { Sacul-Eylau }\end{array}$ & $\begin{array}{l}\text { Alfisol } \\
\text { Ultisol }\end{array}$ & $\begin{array}{l}\text { Deep to very deep moderately well } \\
\text { drained, slowly permeable soils. }\end{array}$ & $\begin{array}{l}\text { On Pleistocene terraces and remnants of } \\
\text { terraces on broad ridges and upland } \\
\text { positions. }\end{array}$ \\
\hline \multirow{2}{*}{$\begin{array}{l}\text { Cypress Creek } \\
\text { River Basin }\end{array}$} & $\begin{array}{l}\text { Socagee-Mooreville- } \\
\text { Mantachie-luka- } \\
\text { Guyton }\end{array}$ & $\begin{array}{l}\text { Inceptisol } \\
\text { Alfisol Entisol }\end{array}$ & $\begin{array}{l}\text { Deep to very deep, poorly to } \\
\text { moderately well drained soils. }\end{array}$ & On the bottomlands of floodplain. \\
\hline & $\begin{array}{l}\text { Mollville-Latch- } \\
\text { Bienville }\end{array}$ & Alfisol & $\begin{array}{l}\text { Very deep, moderately to somewhat } \\
\text { excessively drained, slowly to } \\
\text { moderately permeable soils. }\end{array}$ & $\begin{array}{l}\text { On gently sloping and nearly level or } \\
\text { depressional positions on stream terraces. }\end{array}$ \\
\hline \multirow{3}{*}{$\begin{array}{l}\text { Neches River } \\
\text { Basin }\end{array}$} & $\begin{array}{l}\text { Pophers-Ozias- } \\
\text { Koury }\end{array}$ & $\begin{array}{l}\text { Inceptisol } \\
\text { Vertisol }\end{array}$ & $\begin{array}{l}\text { Very deep, somewhat poorly drained } \\
\text { slowly permeable soils. }\end{array}$ & On nearly level floodplains. \\
\hline & Mantachie-Estes & $\begin{array}{l}\text { Inceptisol } \\
\text { Vertisol }\end{array}$ & $\begin{array}{l}\text { Very deep, somewhat poorly drained, } \\
\text { moderately permeable, loamy and } \\
\text { clayey soils. }\end{array}$ & On nearly level floodplains. \\
\hline & $\begin{array}{l}\text { Tuscosso-Marietta- } \\
\text { Mantachie-luka- } \\
\text { Hannahatchee }\end{array}$ & $\begin{array}{l}\text { Inceptisol } \\
\text { Entisol }\end{array}$ & $\begin{array}{l}\text { Very deep, moderately well to } \\
\text { somewhat poorly drained, moderately } \\
\text { permeable soils. }\end{array}$ & $\begin{array}{l}\text { On nearly level soils along streams and } \\
\text { bottom lands in the flood plain. }\end{array}$ \\
\hline \multirow{6}{*}{$\begin{array}{l}\text { Sabine River } \\
\text { Basin }\end{array}$} & $\begin{array}{l}\text { Texark-Kaufman- } \\
\text { Gladewater }\end{array}$ & Vertisol & $\begin{array}{l}\text { Very deep, somewhat poorly drained, } \\
\text { very slowly permeable clay soils that } \\
\text { formed in clayey alluvium. }\end{array}$ & These soils are found on the floodplain. \\
\hline & Nahatche & Entisol & $\begin{array}{l}\text { Very deep, somewhat poorly drained, } \\
\text { moderately permeable soils. }\end{array}$ & $\begin{array}{l}\text { On floodplains of streams draining soils of } \\
\text { the Southern Coastal Plain. }\end{array}$ \\
\hline & Mantachie-Estes & $\begin{array}{l}\text { Inceptisol } \\
\text { Vertisol }\end{array}$ & $\begin{array}{l}\text { Very deep, somewhat poorly drained, } \\
\text { moderately permeable, loamy and } \\
\text { clayey soils. }\end{array}$ & On nearly level floodplains. \\
\hline & $\begin{array}{l}\text { Mollville-Latch- } \\
\text { Bienville }\end{array}$ & Alfisol & $\begin{array}{l}\text { Very deep, moderately to somewhat } \\
\text { excessively drained, slowly to } \\
\text { moderately permeable soils. }\end{array}$ & $\begin{array}{l}\text { On gently sloping and nearly level or } \\
\text { depressional positions on stream terraces. }\end{array}$ \\
\hline & $\begin{array}{l}\text { Guyton-Estes- } \\
\text { Deweyville-Arat }\end{array}$ & $\begin{array}{l}\text { Alfisol Vertisol } \\
\text { Histisol } \\
\text { Entisol }\end{array}$ & $\begin{array}{l}\text { Very deep, poorly and very poorly } \\
\text { drained, slowly and moderately rapid } \\
\text { permeable. }\end{array}$ & $\begin{array}{l}\text { On stream floodplains and in depressional } \\
\text { areas on late Peistocene age terraces. } \\
\text { Deweyville is also in swamps and poorly } \\
\text { defined drainageways. }\end{array}$ \\
\hline & $\begin{array}{l}\text { Mollville-Mantachie- } \\
\text { Bienville-Besner }\end{array}$ & $\begin{array}{l}\text { Alfisol } \\
\text { Inceptisol }\end{array}$ & $\begin{array}{l}\text { Very deep, poorly drained to } \\
\text { somewhat excessively drained, } \\
\text { moderately to slowly permeable soils. }\end{array}$ & $\begin{array}{l}\text { On Pleistocene terraces. Typically first level } \\
\text { terraces, but is also on third and fourth } \\
\text { level on larger river systems. Mantachie } \\
\text { series is also found on the floodplain. }\end{array}$ \\
\hline \multirow{2}{*}{$\begin{array}{l}\text { Trinity River } \\
\text { Basin }\end{array}$} & $\begin{array}{l}\text { Kaman-Hatliff- } \\
\text { Fausse }\end{array}$ & $\begin{array}{l}\text { Inceptisol } \\
\text { Vertisol } \\
\text { Entisol }\end{array}$ & $\begin{array}{l}\text { Very deep, poorly to moderately well- } \\
\text { drained, very slowly to moderately } \\
\text { rapid permeability. }\end{array}$ & $\begin{array}{l}\text { On nearly level floodplains. Fausse series } \\
\text { is found in ponded backswamp areas. }\end{array}$ \\
\hline & $\begin{array}{l}\text { Tinn-Kaufman- } \\
\text { Gladewater }\end{array}$ & Vertisol & $\begin{array}{l}\text { Very deep, moderately well drained to } \\
\text { somewhat poorly drained very slowly } \\
\text { permeable clayey soils. }\end{array}$ & On nearly level floodplains. \\
\hline
\end{tabular}




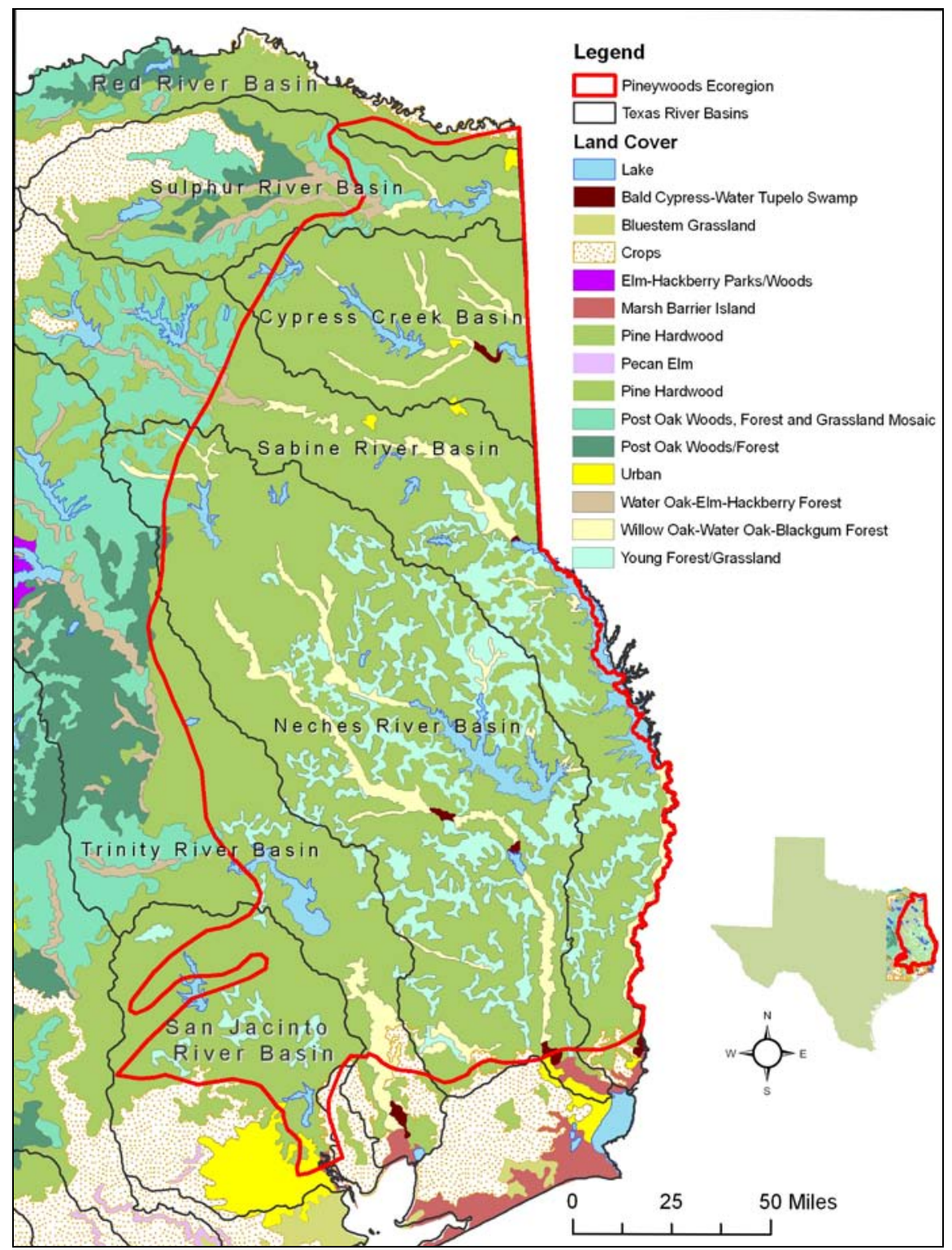

Figure 8. Principal land cover categories in East Texas

(Source: Texas Parks and Wildlife Department 2009).

(Q. pagoda), laurel oak (Q. laurifolia), Shumard oak (Q. shumardii), elms (Ulmus sp.), sweetgum (Liquidambar styraciflua), southern magnolia (Magnolia grandiflora), red maple (Acer rubrum), ironwood (Carpinus caroliniana), sugarberry (Celtis laevigata), green ash (Fraxinus pennsylvanica), baldcypress (Taxodium distichum), water elm (Planera aquatica), deciduous holly (Ilex decidua), poison ivy (Toxicodendron radicans), greenbrier (Smilax sp.), dewberry (Rubus sp.), trumpet creeper (Campsis radicans), jessamine (Gelsemium sp.), St. Andrew's-cross (Hypericum hypericoides), muscadine grape (Vitis rotundifolia), 
supplejack (Berchemia scandens), switchcane (Arundinaria gigantea), and wild oats (Chasmanthium latifolium).

The relationships between tree species distribution and alluvial microtopography are similar to those reported in other river valleys in the southeastern United States (Wharton et al. 1982). In the southern Neches River floodplain, Nixon et al. (1977) observed that ridges were dominated by ironwood and water oak, and flats were occupied by Carolina ash (Fraxinus caroliniana) and snowbell (Styrax americana). Other species observed in abundance were deciduous holly and red maple. Matos and Rudolph (1985) recorded overcup oak, laurel oak, sweetgum, black gum, water hickory (Carya aquatica) and American holly (Ilex opaca) in the floodplain of Village Creek, a tributary of the Neches River in southeastern Texas. The mid-story contained ironwood, deciduous holly and two-winged silverbell (Halesia diptera). In a depression near Village Creek, Matos and Rudolph (1985) found sweetgum, blackgum, green ash, baldcypress, and red maple in the overstory, and snowbell, Virginia sweetspire (Itea virginica) and redpanicle dogwood (Cornus racemosa) in the mid-story. A depression adjacent to Catfish Creek in the western Pineywoods of Anderson County was dominated by buttonbush (Cephalanthus occidentalis), water elm, and overcup oak in the deep water areas and water oak and willow oak in areas exposed to shallow water (Weller 1989). Bottomland oak flats adjacent to Big Cypress Bayou near Caddo Lake, TX were dominated by willow oak, overcup oak, black gum and sweetgum (Van Kley and Hine 1998). The shrubs observed included apple haw (Crataegus opaca), persimmon (Diospyros virginiana), snowbell, deciduous holly, and swamp privet (Forestiera accuminata).

The three most abundant non-native, invasive plant species found in East Texas are J apanese honeysuckle (Lonicera japonica), Chinese tallowtree (Triadica sebifera), and Chinese privet (Ligustrum sinense) (Rudis et al. 2003). Non-native, invasive plant species displace native species, and are generally regarded as potentially detrimental to ecosystem function. Chinese tallowtree is of particular concern within the reference domain due to its broad adaptability and rapid dispersal mechanisms. It is a medium-sized tree that flowers early, tolerates a range of soil conditions, is flood tolerant and shade tolerant, and is resistant to native diseases and insects (Miller 2003). Chinese tallowtree seed can remain viable in the seed bank for at least 7 years (Bruce et al. 1997). The seeds are readily dispersed by birds and floodwater. Great numbers of Chinese tallowtree 
seedlings can rapidly establish in natural and man-made gaps in the forest canopy, even if evidence of the species was absent prior to the disturbance (Williams et al. 2002).

\section{Definition and Identification of the HGM Classes and Subclasses}

Brinson (1993a) identified five wetland classes based on hydrogeomorphic criteria, as described in Chapter 2. These are Flat, Riverine, Depression, Slope, and Fringe wetlands, and all five classes are represented in alluvial valleys of East Texas. Within each class, one or more subclasses are recognized. Wetlands often intergrade or have unusual characteristics; therefore, a set of specific criteria have been established to assist the user in assigning any particular wet-land to the appropriate class (Figure 9). Subclass designations can best be assigned using the descriptions of wetlands and their typical landscape positions presented in the following paragraphs and summarized in Table 5.

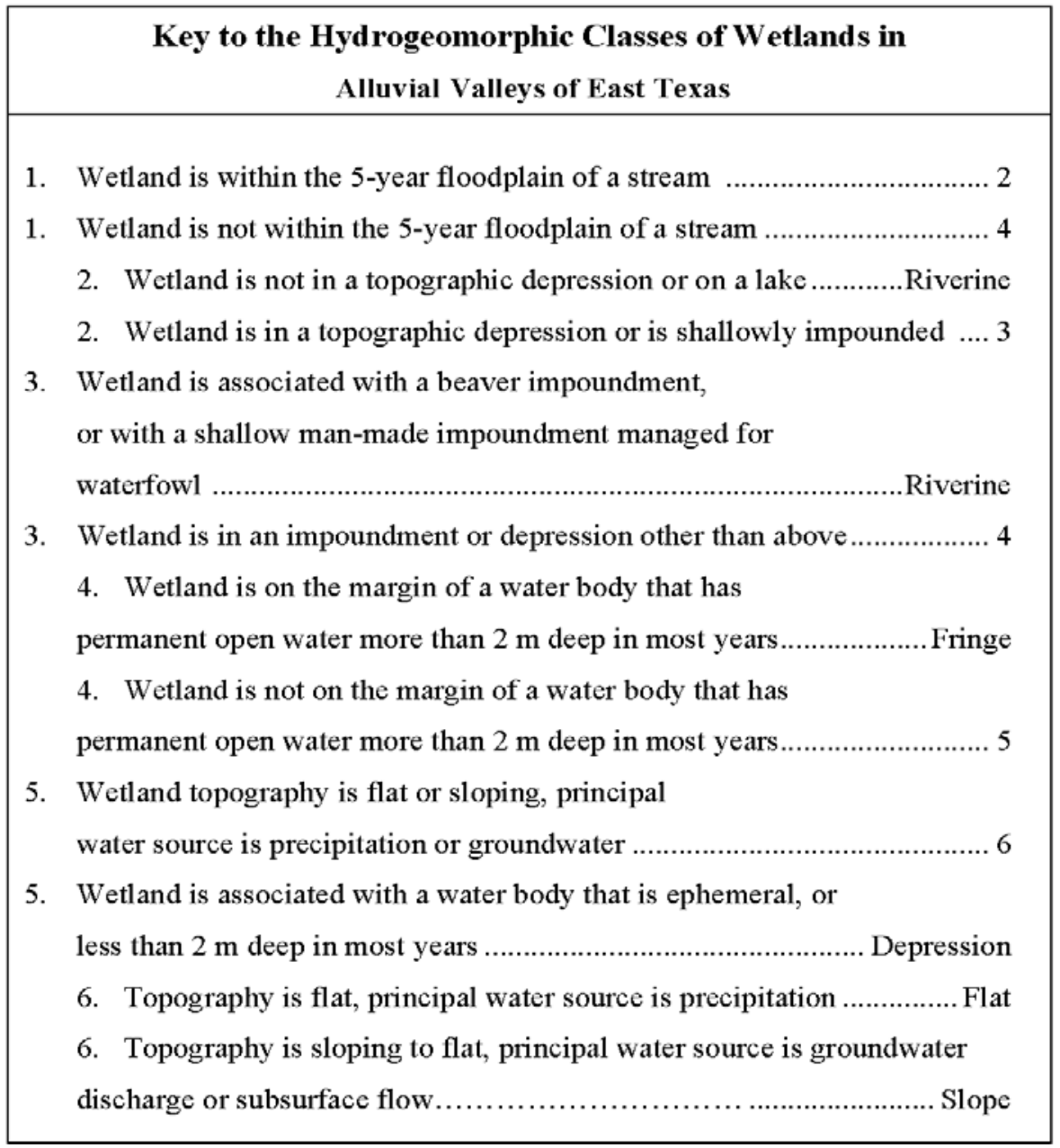

Figure 9. Key to wetland classes in alluvial valleys of East Texas. 
Table 5. Hydrogeomorphic Classification and Typical Geomorphic Settings of Wetlands in Alluvial Valleys of East Texas.

\begin{tabular}{|c|c|c|}
\hline Wetland Class & Subclass & Typical Hydrogeomorphic Setting \\
\hline Flat & Alluvial flat & $\begin{array}{l}\text { Stream terraces, levee-protected former floodplains, and } \\
\text { other poorly drained sites not subject to regular flooding } \\
\text { (outside the 5-year floodplain). }\end{array}$ \\
\hline \multirow[t]{2}{*}{ Riverine } & Mid-Gradient Riverine & $\begin{array}{l}\text { Point bar and natural levee deposits within the } 5 \text {-year } \\
\text { floodplain of streams transitioning from headwaters to } \\
\text { broad basins. }\end{array}$ \\
\hline & Low-Gradient Riverine & $\begin{array}{l}\text { Point bar, backswamp, and natural levee deposits } \\
\text { associated with meandering streams (within the 5-year } \\
\text { floodplain). }\end{array}$ \\
\hline \multirow[t]{2}{*}{ Depression } & Unconnected Depression & $\begin{array}{l}\text { Abandoned channels and large swales in former and } \\
\text { current meander belts of larger rivers not subject to } \\
\text { regular stream flooding (not within the 5-year floodplain). }\end{array}$ \\
\hline & Connected Depression & $\begin{array}{l}\text { Abandoned channels and large swales in former and } \\
\text { current meander belts of larger rivers that are within the } \\
5 \text {-year floodplain. }\end{array}$ \\
\hline \multirow[t]{3}{*}{ Fringe } & $\begin{array}{l}\text { Unconnected Lacustrine } \\
\text { Fringe }\end{array}$ & $\begin{array}{l}\text { Margins of natural and man-made lakes where water } \\
\text { levels are not actively managed, and that are not within } \\
\text { the 5-year floodplain of a larger stream. }\end{array}$ \\
\hline & $\begin{array}{l}\text { Connected Lacustrine } \\
\text { Fringe }\end{array}$ & $\begin{array}{l}\text { Natural and man-made lakes where water levels are not } \\
\text { actively managed, and that are within the 5-year } \\
\text { floodplain of a larger stream. }\end{array}$ \\
\hline & Reservoir Fringe & $\begin{array}{l}\text { Fluctuation zone of a man-made reservoir manipulated } \\
\text { for water supply, power production, and other purposes. } \\
\text { Mostly on former hillslopes of valleys impounded by large } \\
\text { dams. }\end{array}$ \\
\hline Slope & Seep & $\begin{array}{l}\text { Slopes and adjacent colluvial deposits at groundwater } \\
\text { discharge points, usually at the contact between clay } \\
\text { layers and more permeable overlying strata. }\end{array}$ \\
\hline
\end{tabular}

Some of the criteria that are used in Figure 9 and Table 5 require some elaboration. For example, a fundamental criterion is that a wetland must be in the 5-year floodplain of a stream system to be included within the Riverine Class. This return interval is regarded as sufficient to support major functions that involve periodic connection to stream systems. It was also selected as a practical consideration because, where flood return intervals are mapped, the 5-year return interval is a commonly used increment.

The classification system recognizes that certain sites functioning primarily as fringe or depression wetlands also are regularly affected by stream flooding, and therefore have a riverine functional component. This is incorporated in the classification system by establishing "river-connected" 
subclasses within the Fringe and Depression Classes. Similarly, sites that function primarily as riverine wetlands and flats often incorporate small, shallow depressions, sometimes characterized as vernal pools and microdepressions. These features are regarded as normal components of the riverine and flat ecosystems, and are not separated into the Depression Class unless they meet specific criteria. Other significant criteria relating to classification are elaborated upon in the following wetland descriptions.

The following sections briefly describe the classification system developed for this guidebook. All of the wetland types that occur in alluvial valleys of East Texas are described in the following text, but assessment models and supporting reference data were developed for only a subset of these types, as described in Chapter 4.

\section{Class: Flat}

Flats can occur in any setting where poor drainage and level topography cause rainwater to pond at or near the soil surface until it is removed by evapotranspiration. In alluvial valleys in the southern United States, most such sites are on river terraces. As alluvial features, terrace flats usually have a very subtle, rolling topography that causes precipitation to pond for much of the winter and spring. Summer storms also can cause these ephemeral pools (sometimes called vernal pools) to refill and remain ponded for days or weeks during the peak of the growing season, which can eliminate certain plant species and create a diverse patchy pattern within the plant community. Fire may also be an important factor in maintaining patch diversity in terrace flats. Most of the same species found in the less-frequently-flooded parts of low-gradient riverine sites can be found in terrace flats, particularly willow oak and water oak.

Parts of the active meander belts of larger streams can also be classified as flats, based on the 5-year flood frequency criterion. The crests of high natural levees sometimes rise above the 5-year floodplain, and are technically flats under the HGM classification, though they may not be jurisdictional wetlands due to their well-drained soils. These sites usually support the same species found on more flooded natural levee sites, such as cow oak, with cane thickets being common in the understory.

One other category of flat occurs in areas that were historically frequently flooded, but which have had flooding reduced or eliminated by channel incision or engineered flood control projects such as reservoirs and levees. 
These sites are classified as functional flats due to the lack of regular interaction with channel systems, but their plant communities are generally indistinguishable from frequently flooded sites because their alluvial soils and topography effectively pond precipitation and maintain the wetland character of the system.

Terraces outside the 5-year flood zone are not common within the reference domain and very few of them support natural forests, having long ago been converted to agriculture or pine plantations. Therefore, no flat-specific assessment models are presented here. However, the natural vegetation of the flats within East Texas alluvial valleys is very similar to the forests of active floodplains; therefore the models developed for riverine systems can reasonably be applied to flats if they are modified to eliminate model terms related to flood frequency.

\section{Class: Riverine}

The classification used in this guidebook defines wetlands as riverine if they occur within the 5-year floodplain of a stream. Their principal water source is overbank or backwater flooding that, in the reference domain, occurs primarily during the winter and spring. Overbank flooding is characterized by high-velocity flows moving downstream when water overtops the natural levee. Backwater flooding is slack water from impeded tributaries overtopping their banks when the major streams they flow into are near flood stage. Runoff from adjacent uplands and ponding from precipitation are also sources of water. The soil water table is usually near the surface across the entire width of the floodplain during the winter and early spring. The riverine wetlands in the reference domain are typically forested and referred to as bottomland hardwood wetlands. Within the 5-year floodplain, the riverine wetland class is separated into two sub-classes: low-gradient riverine, and mid-gradient riverine. The separation is generally based on the size of the stream and its associated floodplain. Depressions within the 5year floodplain were considered as a separate class. Beaver complexes are considered part of the riverine system where they occur, but are not assessed using HGM criteria (see Chapter 6).

a. Low-gradient riverine. Low-gradient riverine wetlands occur within the floodplains of major rivers. The floodplains can be very wide even along relatively narrow channels, a common feature of modern coastal plain river systems (Bridge 2003). Typically, these systems have large, distinctive geomorphic features and often receive both backwater and 
overbank flooding (though no subclass distinction between overbank flooding and backwater flooding is made in this document). The frequency of flooding is between 1 and 5 years. The duration of flooding ranges from days to several weeks. Areas of higher elevation-ridges and natural levees - will drain first after flooding. Swales will hold water longer after flooding and ponding of precipitation is common during winter and spring. Duringyears of normal rainfall, the swales will be dry from early summer to late fall. The water table is near the surface during the winter and spring, but rapidly drops as the growing season progresses. The soil orders typically observed are Vertisols, Inceptisols and Entisols. Adjacent to rivers, black willow (Salix nigra), eastern cottonwood (Populus deltoides), and river birch (Betula nigra) are common. On the natural levees and ridges, weakly flood tolerant to moderately flood tolerant species such as water oak, willow oak, and black gum are present. Drier ridges will often support cherrybark oak and cow oak. Wetter ridges may have willow oak, laurel oak and Nuttall oak (Quercus nuttallii). The herbaceous stratum on the ridges may have a high abundance of switchcane and wild oats. Ironwood, deciduous holly and red maple are common in the understory. The tree and sapling/ shrub densities are lower in the swales and overcup oak usually dominates. The herbaceous stratum cover in the swales is often sparse. Backswamps can be dominated by green ash and red maple. Sweetgum is ubiquitous throughout the floodplain.

b. Mid-gradient riverine. The mid-gradient riverine subclass is characterized by small streams and floodplains. These systems may be referred to as minor bottoms (Hodges 1998). The frequency of flooding is from 1 to 5 years with annual flooding common. Mid-gradient riverine sites typically receive overbank flooding with flood durations of hours to days. Multiple flood events interspersed with long dry periods can occur throughout the year. They have geomorphic features and soil characteristics that are similar to, but smaller in scale than the low-gradient riverine subclass. They are typically forested and support many of the same plant species as the low-gradient riverine subclass. However, species such as American elm (Ulmus americana), slippery elm (Ulmus rubra), winged elm (Ulmus alata), cedar elm (Ulmus crassifolia), river birch, box-elder (Acer negundo), hawthorn (Crataegus spp.) and loblolly pine (Pinus taeda) can be found in greater abundance. Some mid-gradient riverine locations have been converted to pasture or pine plantations. 


\section{Class: Depression}

Depressions are located primarily within the 5-year floodplain of the major rivers. They are distinguishable from the ephemeral (vernal) pools on flats and floodplains by clearly being deeper, larger, concave landforms that hold surface water for much or all of the growing season in most years. Many depressions are recent abandoned channels that still maintain a discernible hydrologic connection to the river. The soils in depressions typically have more clay, lower chroma, and many redox concentrations compared to the soils in the surrounding floodplain. Plant cover tends to be sparse, at least in the deepest parts of the depression, and usually, the herbaceous stratum is absent or limited to localized populations of hydrophytes such as lizard's tail (Saururus cenruus). The common tree and shrub species are overcup oak, water elm, baldcypress, water tupelo (Nyssa aquatica), water hickory, and green ash. Where canopy trees are largely lacking due to disturbance, buttonbush and smartweeds (Polygonum spp.) commonly dominate.

Two depression subclasses may be recognized strictly on the basis of flood frequency. There are no differences in vegetation structure and composition between them.

a. Connected Depression

Connected depressions occur within the 5-year floodplain of a stream.

c. Unconnected Depression

Unconnected depressions occur outside the 5-year floodplain of a stream.

\section{Class: Fringe}

Fringe wetlands occur along the margins of lakes. By convention, a lake must be more than $2 \mathrm{~m}$ ( $6 \mathrm{ft}$ ) deep; otherwise, associated wetlands are classified as depressions.

In East Texas alluvial valleys, natural lakes occur mostly in the abandoned channels of large rivers (oxbows), but numerous man-made impoundments also support fringe wetlands. There are three subclasses in the fringe class (Table 5). No assessment models have been developed for any of the fringe wetland subclasses, primarily because no single reference system can reflect the range of variability they exhibit. In particular, many water bodies that 
support fringe wetlands are subject to water level controls, but the resulting fluctuation patterns are highly variable depending on the purpose of the control structure.

a. Reservoir shore. Man-made reservoirs include a wide array of features, such as large farm ponds; state, Federal, and utility company lakes; and municipal water storage reservoirs. In almost all cases, these lakes are managed specifically to modify natural patterns of water flow; therefore, their shoreline habitats are subjected to inundation at times and for durations not often found in nature. Steep reservoir shores usually support little perennial wetland vegetation other than a narrow fringe of willows. The most extensive wetlands within reservoirs usually occur where tributary streams enter the lake, and sediments accumulate to form deltas. These sites may be colonized by various marsh species, and sometimes black willow or buttonbush; but even these areas are vulnerable to extended drawdowns, ice accumulation, erosion caused by boat wakes, and similar impacts.

b. Connected lake margin. Large connected lake margin wetlands are uncommon in the reference domain. However, smaller lakes such as stock ponds and borrow pits that are frequently inundated during floods (that is, they are within the 1- to 5-year flood frequency zone) may support connected lake margin wetlands. Connected lake margins differ from unconnected systems in that they routinely exchange nutrients, sediments, and aquatic organisms with the river system. Shoreline willow stands and fringe marshes are the typical vegetation.

c. Unconnected lake margin. Unconnected lakes are lakes that are not inundated by a river on a regular basis (that is, they are not within the 1- to 5-year floodplain). They are similar in appearance to connected lake margins but are classified separately because they do not regularly exchange nutrients, sediments, or fish with river systems. In the reference domain, most unconnected lake margin wetlands are in small man-made ponds.

\section{Class: Slope}

Slope wetlands occur on or below sloping land surfaces where groundwater discharge or shallow subsurface flow creates saturated conditions. In the alluvial valleys of East Texas, these seep wetlands occur primarily on the lower parts of valley walls or on terraces where they contact valley walls. 
They tend to be found where permeable materials (especially sands) sit atop relatively impermeable layers, causing lateral movement of groundwater. Typically, where groundwater flow is relatively constant (perennial seeps) these sites support diverse communities of herbaceous plants, but the specific composition can vary widely. Beakrushes (Rhynchospora spp.) are commonly present, as are various carnivorous plant species such as pitcher plants (Sarracenia spp.) and sundews (Drosera spp.). Where the seepage is more seasonal or intermittent (wet-weather seeps), woody species also may occur, including sweetbay magnolia (Magnolia virginiana), blackgum, and a variety of shrubs such as waxmyrtle (Myrica cerifera) and possumhaw (Viburnum nudum) (Diggs et al. 2006). The structure of seep communities also can be strongly influenced by fire (German 2005).

In alluvial valleys of East Texas, seep wetlands tend to be very small, and few of them occur on alluvial surfaces. Where they do occur, they are sufficiently rare and support such unusual species that they are likely to be considered to be of special concern based on one or more criteria. Therefore, this guidebook does not include assessment models for this wetland class. 


\section{Wetland Functions and Assessment Models}

This Regional Guidebook contains assessment models applicable to the most common forested wetlands in the alluvial alleys of East Texas. These are the low-gradient riverine, mid-gradient riverine, and connected depression subclasses. The other wetland subclasses that occur within the reference domain are uncommon or are excluded for other reasons, but alternative approaches to their assessment are available if needed, as follows:

a. Most fringe wetlands are highly functional, and comprise a complex of community types that occur in zones that reflect a wide variety of potential water depths, energy regimes, and fluctuation patterns. No generalized reference system can adequately reflect that complexity; therefore fringe wetlands are beyond the scope of any rapid assessment approach. Proposed impacts to fringe wetlands should be evaluated on a site-specific basis, using the existing community as the reference wetland, particularly if the proposed impacts involve changes to water regimes.

b. Slope wetlands within the reference domain are unique systems of very limited spatial extent. Although they occur within alluvial valleys, they are not often associated with alluvium, but rather with groundwater discharge areas along the valley walls. They further differ from the lowland forested systems that are the focus of this guidebook in that they are characterized by the presence of unique and often rare plant species. At this time, the most appropriate approach for assessing these systems should involve evaluation of the water source and impacts to the source area, and a detailed floristic inventory. Both of these are beyond the scope of a rapid field assessment technique like HGM, therefore no assessment criteria for slope wetlands are included in this guidebook. However, if the principal impacts to such systems involve alteration of vegetation structure, then the slope wetland assessment models developed for the Gulf Coastal Plain Region of Arkansas (Klimas et al. 2005) might reasonably be applied in East Texas, at least in certain circumstances. Prior to adopting this approach, the characteristics of the wetland should be described in sufficient detail to 
demonstrate that it is similar to the wetlands sampled in the same subclass in Arkansas.

c. Unconnected depression wetlands and flats are very uncommon in the reference domain, and not enough reference sites could be located to fully characterize the reference condition for either of them. However, the few sites available indicated that the same pattern found in other regions would likely apply - that is, the plant community composition and structure are very similar to the more frequently flooded wetlands on similar sites. Therefore, while no reference-based models are presented in this guidebook, the models for connected depressions and low-gradient riverine wetlands could be applied if no alternative assessment approach is satisfactory. In order to do so, the assessment models must be modified to eliminate hydrologic variables, and the 'Export Carbon" function cannot be used in the assessment, as infrequently flooded sites have little significant downstream connectivity. Any analysis that uses modified models to assess relatively uncommon wetlands should be clearly identified as such and the pertinent modifications and assumptions should be described.

d. No models are available that are specific to managed wildlife impoundments (greentree reservoirs and moist soil management units). However, where existing wetlands are proposed to be converted to managed impoundments, the models appropriate to the impact area can be used to assess the functional change likely to occur from altered water regimes (see “Apply Assessment Results” in Chapter 6).

e. Beaver-influenced wetlands cannot be assessed using simple structural and compositional indicators, because of the highly dynamic and spatially diverse nature of those systems. They should be regarded as fully functional components of the riverine system, but the HGM models presented here can be used to assess only those portions of the riverine system that is not significantly modified by beaver activity.

As noted in Chapter 1, the wetland functions that can be assessed using this guidebook, and the model structure and model variables used to conduct assessments, were selected by participants in a workshop held in Nacogdoches, TX in November 2006. That group directed that the East Texas HGM guidebook should be as consistent as possible with the HGM guidebook previously developed for application in the West Gulf Coastal 
Plain region of Arkansas, which is geologically, climatically, and floristically similar to East Texas. Therefore, the approach used herein follows the Arkansas precedents to the extent that they are applicable; however, all of the field reference data used to calibrate the assessment models were collected in the East Texas reference domain. The summarized reference data can be accessed from $\mathrm{http}$ ://el.erdc.usace.army.mil/wetlands/datanal.html.

Based on the workshop recommendations, this regional guidebook provides assessment models and methods for conducting assessments of the extent to which the common forested wetlands of alluvial valleys in East Texas perform the following functions:

- Detain Floodwater.

- Detain Precipitation.

- Cycle Nutrients.

- Export Organic Carbon.

- Maintain Plant Communities.

- Provide Habitat for Fish and Wildlife.

Note that not all functions are performed by each regional wetland subclass. In addition, the form of the assessment model that is used to assess functions can vary from subclass to subclass.

Functional scores or indices represent a measure of ecosystem integrity, where the index drops as a wetland deviates from the reference standard condition for variables that contribute to the function. If there is no deviation, the score is 1 ; but as the deviation increases, the score becomes a fraction that approaches zero. This is true even if the actual function might be increasing, but in an unsustainable manner. For instance, a hydrologic change in a forested wetland could stress trees and lead to a large amount of crown dieback, and therefore an increase in woody debris, which would lead to an increase in the actual export of organic carbon to nearby aquatic ecosystems. However, the functional score or index would actually decrease, because this woody-debris spike is a deviation from the amount typical in healthy mature forests of the subclass within the reference domain, hence a deviation from ecosystem integrity.

In this chapter, function is discussed generally in terms of the following topics: 
a. Definition and applicability. This section defines the function and identifies the subclasses where the function is assessed.

b. Rationale for selecting the function. This section discusses the reasons a function was selected for assessment, and the onsite and offsite effects that may occur as a result of lost functional capacity.

c. Characteristics and processes that influence the function. This section describes the characteristics and processes of the wetland and the surrounding landscape that influence the function, and lays the groundwork for the description of assessment variables.

d. General form of the assessment model. This section presents the structure of the general assessment model and briefly describes the constituent variables.

The specific form of the assessment models used to assess functions for each regional wetland subclass and the functional capacity subindex curves are presented in Chapter 5. Chapter 6 presents detailed descriptions of assessment variables and the methods used to measure or estimate their values.

\section{Function 1: Detain Floodwater}

\section{Definition and applicability}

This function reflects the ability of wetlands to store, convey, and reduce the velocity of floodwater as it moves through a wetland. The potential effects of this reduction are damping of the downstream flood hydrograph, maintenance of postflood base flow, and deposition of suspended sediments from the water column to the wetland. This function is assessed for the following regional wetland subclasses in the alluvial valleys of East Texas:

- Low-Gradient Riverine.

- Mid-Gradient Riverine.

- Connected Depression.

The recommended procedure for assessing this function involves estimation of "roughness" within the wetland and deviation from the expected flood frequency pattern for the site. 


\section{Rationale for selecting the function}

The capacity of wetlands to store and convey floodwater temporarily has been extensively documented (Dewey and Kropper Engineers 1964; Campbell and J ohnson 1975; Novitski 1978; Thomas and Hanson 1981; Ogawa and Male 1983, 1986; Demissie and Kahn 1993). Generally, floodwater interaction with wetlands dampens and broadens the flood wave, which reduces peak discharge downstream. Similarly, wetlands can reduce the velocity of water currents and, as a result, reduce erosion (Ritter et al. 1995). Some portion of the floodwater volume detained within floodplain wetlands is likely to be evaporated or transpired, reducing the overall volume of water moving downstream. The portion of the detained flow that infiltrates into the alluvial aquifer or returns to the channel very slowly via low-gradient surface routes may be sufficiently delayed that it contributes significantly to the maintenance of base flow in some streams long after flooding has ceased (Terry et al. 1979; Saucier 1994). Retention of particulates also is an important component of the flood detention function because sediment deposition directly alters the physical characteristics of the wetland (including hydrologic attributes) and influences downstream water quality.

This function deals specifically with these physical influences on flow and sediment dynamics. Floodwater interaction with floodplain wetlands influences a variety of other wetland functions in the alluvial valleys of East Texas, including nutrient mobility and storage and the quality of habitat for plants and animals. The role of flooding in maintaining these functions is considered separately in other sections of this chapter.

\section{Characteristics and processes that influence the function}

The capacity of a wetland to detain and moderate floodwaters is related to the characteristics of the particular flood event, the configuration and slope of the floodplain and channel, and the physical obstructions present within the wetland that interfere with flows. The intensity, duration, and spatial extent of precipitation events affect the magnitude of the stream discharge response. Typically, rainfall events of higher intensity, longer duration, and greater spatial extent result in greater flood peaks. Watershed characteristics such as size and shape, channel and watershed slopes, drainage density, and the presence of wetlands and lakes have pronounced effects on the stormflow response (Dunne and Leopold 1978; Patton 1988; Brooks et al. 1991; Leopold 1994; Ritter et al. 1995). 
The duration of water storage is secondarily influenced by the slope and roughness of the floodplain. Slope refers to the gradient of the floodplain across which floodwaters flow. Roughness refers to the resistance to flow created by vegetation, debris, and topographic relief. In general, duration increases as roughness increases and slope decreases.

Of these characteristics, only flood frequency and the roughness component can be reasonably incorporated into a rapid assessment. Most stream channels in the region are not close enough to a stream gage to ascribe detailed flood characteristics to any particular point on the ground. At best, flood frequency can be estimated for some sites, at least to the extent needed to classify a wetland as riverine or connected (i.e., within the 5-year floodplain). In cases where a change in flood frequency caused by a proposed project can be estimated, that information can be used in the assessment of this function. Otherwise, the only element of the Floodwater Detention function that is assessed is roughness.

\section{General form of the assessment model}

The model for assessing the Detain Floodwater function includes five assessment variables, which are discussed in greater detail in Chapter 6:

$$
\begin{aligned}
\mathrm{V}_{\mathrm{FREQ}} & =\text { change in frequency of flooding } \\
\mathrm{V}_{\text {LOG }} & =\text { log density } \\
\mathrm{V}_{\mathrm{GVC}} & =\text { ground vegetation cover } \\
\mathrm{V}_{\text {SSD }} & =\text { shrub-sapling density } \\
\mathrm{V}_{\mathrm{TDEN}} & =\text { tree density }
\end{aligned}
$$

The model can be expressed in a general form:

$$
\mathrm{FCI}=\mathrm{V}_{\mathrm{FREQ}} \times\left[\frac{\left(\mathrm{V}_{\mathrm{LOG}}+\mathrm{V}_{\mathrm{GVC}}+\mathrm{V}_{\mathrm{SSD}}+\mathrm{V}_{\mathrm{TDEN}}\right)}{4}\right]
$$

The assessment model has two components: change in frequency of flooding ( $\mathrm{V}_{\mathrm{FREQ}}$ ) and a compound expression that represents flow resistance (roughness) within the wetland. The flood frequency variable is employed as a multiplier, such that the significance of the roughness component is proportional to how often the wetland is inundated relative to the reference inundation frequency for the site. 
The compound expression of flow resistance includes the major physical components of roughness that can be characterized readily at the level of a field assessment. They include elements that influence flow velocity differently depending on flood depth and time of year. For example, ground vegetation cover ( $\mathrm{V}_{\mathrm{GVC}}$ ) and log density ( $\mathrm{V}_{\mathrm{LOG}}$ ) can effectively disrupt shallow flows, while shrub and sapling density (VSSD) have their greatest influence on flows that intercept understory canopies (usually 1 to $3 \mathrm{~m}$ deep), and tree stems ( $V_{\text {TDENS }}$ interact with a full range of flood depths. Both tree stems and logs are equally effective in disrupting flows at all times of the year, while understory and ground cover interactions are less effective during winter floods than during the growing season. Other components of wetland structure contribute to roughness, but are not assessed here because they do not commonly influence flows to the same degree as these components (e.g., snag density).

\section{Function 2: Detain Precipitation}

\section{Definition and applicability}

This function is defined as the capacity of a wetland to store rainfall onsite, thereby maintaining wetland characteristics and moderating runoff to streams. This is accomplished chiefly by microdepressional storage, infiltration, and absorption by organic material and soils. Both riverine and depression wetlands store precipitation, but depressions are not assessed for that function within the alluvial valleys of East Texas. The hydrology of depression wetlands is dependent on highly variable source areas, groundwater movement, and available storage volumes, which are difficult to measure within the constraints of a rapid field assessment. Two wetland subclasses are assessed for the precipitation detention function in the alluvial valleys of East Texas:

- Low-gradient riverine.

- Mid-gradient riverine.

The recommended procedure for assessing this function is estimation of available microdepression storage and characterization of the extent of organic surface accumulations available to improve absorption and infiltration. 


\section{Rationale for selecting the function}

Like the floodwater detention function, capture and detention of precipitation prevents erosion, dampens runoff peaks following storms, and helps maintain base flow in streams (Meyer et al. 2003). The stream hydrograph has a strong influence on the development and maintenance of habitat structure and biotic diversity of adjacent ecosystems (Bovee 1982; Estes and Orsborn 1986; Stanford et al. 1996). In addition, onsite storage of precipitation may be important in maintaining wetland conditions on the site, independent of the influence of flooding. The presence of ponded surface water and recharge of soil moisture also have implications for plant and animal communities within the wetland, but these effects are assessed separately.

\section{Characteristics and processes that influence the function}

Riverine wetlands capture precipitation and local runoff in microdepressions and vernal pools. Microdepressions are usually formed by channel migration processes or tree windthrow, which creates small, shallow depressions when root systems are pulled free of the soil. Vernal pools are usually found in ridge-and-swale topography, or they can be created by the gradual filling of once deeper depressions such as cutoffs or oxbows. The presence of surface organic accumulations also reduces runoff and promotes infiltration. Therefore, sites with large amounts of microdepression and vernal pool storage and a continuous litter layer will most effectively reduce the movement of precipitation as overland flow. Instead, the water is detained onsite, where it supports biological processes, contributes to subsurface water storage, and eventually helps maintain base flow in nearby streams. Clearing of natural vegetation cover will remove the source of litter and the mechanism for developing new microdepressions. Land use practices that involve ditching or land leveling can eliminate onsite storage and promote rapid runoff of precipitation.

\section{General form of the assessment model}

The assessment model for the Detain Precipitation function includes three assessment variables, which are discussed in greater detail in Chapter 6:

$$
\begin{aligned}
V_{\text {POND }} & =\text { percent of area subject to ponding } \\
V_{\text {OHOR }} & =\text { O horizon thickness } \\
V_{\text {LITTER }} & =\text { percent cover of the litter layer }
\end{aligned}
$$


The model can be expressed in a general form:

$$
\mathrm{FCI}=\frac{\left[\mathrm{V}_{\mathrm{POND}}+\frac{\left(\mathrm{V}_{\mathrm{OHOR}}+\mathrm{V}_{\text {LTTER }}\right)}{2}\right]}{2}
$$

The assessment model has two components, which are weighted equally. The percentage of the assessment area subject to ponding $\left(V_{\text {POND }}\right)$ is based on a field estimate. The second component expression is an average based on field measures of organic matter accumulation on the soil surface, which are represented by the thickness of the $\mathrm{O}$ horizon $\left(\mathrm{V}_{\mathrm{OHOR}}\right)$ and the percentage of the ground surface covered by litter ( $\left.\mathrm{V}_{\text {LITTER }}\right)$. Litter is sometimes a problematic variable to use, because it is seasonal in nature. However, litter is an important element in precipitation detention, and may be differentially exported from some riverine sites; therefore, it is included in the model despite the inherent difficulties. If users of this guidebook determine that litter cannot be estimated reliably in the wetland being assessed (for example, if field work in two areas being compared will span several seasons), then litter can be removed from the model equation, and the model structure revised appropriately.

\section{Function 3: Cycle Nutrients}

\section{Definition and applicability}

This function refers to the ability of the wetland to convert nutrients from inorganic forms to organic forms and back through a variety of biogeochemical processes such as photosynthesis and microbial decomposition. In the context of this assessment procedure, it also includes the capacity of the wetland to permanently remove or temporarily immobilize elements and compounds that are imported to the wetland, particularly by floodwaters. The nutrient cycling function encompasses a complex web of chemical and biological activities that sustain the overall wetland ecosystem, and it is assessed in all wetland subclasses. The assessed subclasses discussed within this document include the following:

- Low-Gradient Riverine.

- Mid-Gradient Riverine.

- Connected Depression. 
The assessment procedure described here utilizes indicators of the presence and relative magnitude of organic material production and storage, including living vegetation strata, dead wood, detritus, and soil organic matter.

\section{Rationale for selecting the function}

In functional wetlands, nutrients are transferred among various components of the ecosystem such that materials stored in each component are sufficient to maintain ecosystem processes (Ovington 1965; Pomeroy 1970). For example, an adequate supply of nutrients in the soil profile supports primary production, which makes plant community development and maintenance possible (Bormann and Likens 1970; Whittaker 1975; Perry 1994). The plant community, in turn, provides a pool of nutrients and source of energy for secondary production and also provides the habitat structure necessary to maintain the animal community (Fredrickson 1978; Wharton et al. 1982). Plant and animal communities serve as the source of detritus, which provides nutrients and energy necessary to maintain a characteristic community of decomposers. These decomposers, in turn, break down organic material into simpler elements and compounds that can then reenter the nutrient cycle (Reiners 1972; Dickinson and Pugh 1974; Pugh and Dickinson 1974; Schlesinger 1977; Singh and Gupta 1977; Hayes 1979; Harmon et al. 1986; Vogt et al. 1986).

\section{Characteristics and processes that influence the function}

In wetlands, nutrients are stored within and cycled among four major compartments: (a) the soil, (b) primary producers such as vascular and nonvascular plants, (c) consumers such as animals, fungi, and bacteria, and (d) dead organic matter, such as leaf litter or woody debris, referred to as detritus. The transformation of nutrients within each compartment and the flow of nutrients between compartments are mediated by a complex variety of biogeochemical processes. For example, plant roots take up nutrients from the soil and detritus and incorporate them into the organic matter in plant tissues. Nutrients incorporated into herbaceous or deciduous parts of plants will turn over more rapidly than those incorporated into the woody parts of plants. However, ultimately, all plant tissues are either consumed or die and fall to the ground where they are decomposed by fungi and microorganisms and mineralized to become available again for uptake by plants. The processes involved in nutrient cycling within wetlands of the southern United States have been studied extensively (Conner and Day 
1976; Day 1979; Brinson et al. 1981; Mulholland 1981; Brown and Peterson 1983; Harmon et al. 1986; Brinson 1990).

\section{General form of the assessment model}

The model for assessing the nutrient cycling function includes the following assessment variables, which are discussed in greater detail in Chapter 6:

$$
\begin{aligned}
\mathrm{V}_{\mathrm{TBA}} & =\text { tree basal area } \\
\mathrm{V}_{\mathrm{SSD}} & =\text { shrub-sapling density } \\
\mathrm{V}_{\mathrm{GVC}} & =\text { ground vegetation cover } \\
\mathrm{V}_{\mathrm{OHOR}} & =\text { O horizon thickness } \\
\mathrm{V}_{\mathrm{AHOR}} & =\text { A horizon thickness } \\
\mathrm{V}_{\mathrm{WD}} & =\text { woody debris biomass } \\
\mathrm{V}_{\mathrm{SNAG}} & =\text { snag density }
\end{aligned}
$$

The model can be expressed in a general form:

$$
\mathrm{FCI}=\frac{\left[\frac{\left(\mathrm{V}_{\mathrm{TBA}}+\mathrm{V}_{\mathrm{SSD}}+\mathrm{V}_{\mathrm{GVC}}\right)}{3}+\frac{\left(\mathrm{V}_{\mathrm{OHOR}}+\mathrm{V}_{\mathrm{AHOR}}+\mathrm{V}_{\mathrm{WD}}+\mathrm{V}_{\mathrm{SNAG}}\right)}{4}\right]}{2}
$$

The two constituent expressions within the model reflect the two major production and storage compartments: living and dead organic material. The first expression is composed of indicators of living biomass, expressed as tree basal area $\left(\mathrm{V}_{\mathrm{TBA}}\right)$, shrub and sapling density $\left(\mathrm{V}_{\mathrm{SSD}}\right)$, and ground vegetation cover $\left(\mathrm{V}_{\mathrm{GVC}}\right)$. These various living components also reflect varying levels of nutrient availability and turnover rates, with the aboveground portion of ground cover biomass being largely recycled on an annual basis, while understory and tree components incorporate both short-term storage (leaves) as well as long-term storage (wood). Similarly, the second expression includes organic storage compartments that reflect various degrees of decay. Snag density ( $\mathrm{V}_{\mathrm{SNAG}}$ ) and woody debris volume $\left(\mathrm{V}_{\mathrm{WD}}\right)$ represent relatively long-term storage compartments that are gradually transferring nutrients into other components of the ecosystem through the mediating activities of fungi, bacteria, and higher plants. The thickness of the $\mathrm{O}$ horizon ( $\mathrm{V}_{\mathrm{OHOR}}$ ) represents a shorter-term storage compartment of largely decomposed, but nutrient-rich organics on the soil surface. The thickness of the A horizon (actually, the portion of the A horizon where organic accumulation is apparent) $\left(\mathrm{V}_{\mathrm{AHOR}}\right)$ represents a 
longer-term storage compartment, where nutrients that have been released from other compartments are held within the soil and are available for plant uptake, but are generally conserved within the system and not readily subject to export by runoff or floodwater.

All of these components are combined here in a simple arithmetic model, which weights each element equally. Note that one detrital component, litter accumulation, is not used in this model. This is a relatively transient component of the onsite nutrient capital, and may be readily exported. Therefore it is used as a nutrient-related assessment variable only in the carbon export function.

\section{Function 4: Export Organic Carbon}

\section{Definition and applicability}

This function is defined as the capacity of the wetland to export dissolved and particulate organic carbon to downstream aquatic systems. The assessment procedure employs indicators of organic production, the presence of organic materials that may be mobilized during floods or groundwater discharge, and the occurrence of periodic flooding to assess the organic export function of a wetland. This function is assessed in riverconnected wetlands, which include the following subclasses in the alluvial valleys of East Texas:

- Low-Gradient Riverine.

- Mid-Gradient Riverine.

- Connected Depression.

\section{Rationale for selecting the function}

The high productivity of river-connected wetlands and their interaction with streams make them important sources of dissolved and particulate organic carbon for aquatic food webs and biogeochemical processes in downstream aquatic habitats (Vannote et al. 1980; Elwood et al. 1983; Sedell et al. 1989). Dissolved organic carbon is a significant source of energy for the microbes that form the base of the detrital food web in aquatic ecosystems (Dahm 1981; Edwards 1987; Schlosser 1991; Wohl 2000). 


\section{Characteristics and processes that influence the function}

Watersheds with a large proportion of wetlands generally have been found to export organic carbon at higher rates than watersheds with fewer wetlands. This is attributable to several factors: (a) the large amount of organic matter in the litter and soil layers that comes into contact with floodwaters, overland flow, or groundwater discharge; (b) relatively long periods of inundation or saturation and, consequently, contact between surface water and organic matter, thus allowing for significant leaching; (c) the ability of the labile carbon fraction to be rapidly leached from organic matter when exposed to water; and (d) the ability of floodwater and overland flow to transport dissolved and particulate organic carbon from the wetland to the stream channel or other down-gradient systems (Mulholland and Kuenzler 1979; Brinson et al. 1981; Elder and Mattraw 1982; J ohnston et al. 1990).

\section{General form of the assessment model}

The model for assessing the Export Organic Carbon function includes eight assessment variables, which are discussed in greater detail in Chapter 6:

$$
\begin{aligned}
\mathrm{V}_{\mathrm{FREQ}} & =\text { change in frequency of flooding } \\
\mathrm{V}_{\mathrm{LITTER}} & =\text { percent cover of the litter layer } \\
\mathrm{V}_{\mathrm{OHOR}} & =\text { O horizon thickness } \\
\mathrm{V}_{\mathrm{WD}} & =\text { woody debris biomass } \\
\mathrm{V}_{\mathrm{SNAG}} & =\text { snag density } \\
\mathrm{V}_{\mathrm{TBA}} & =\text { tree basal area } \\
\mathrm{V}_{\mathrm{SSD}} & =\text { shrub-sapling density } \\
\mathrm{V}_{\mathrm{GVC}} & =\text { ground vegetation cover }
\end{aligned}
$$

The general form of the assessment model follows:

$$
\mathrm{FCI}=\mathrm{V}_{\mathrm{FREQ}} \times \frac{\left[\frac{\left(\mathrm{V}_{\mathrm{LTTTR}}+\mathrm{V}_{\mathrm{OHOR}}+\mathrm{V}_{\mathrm{WD}}+\mathrm{V}_{\mathrm{SNAG}}\right)}{4}\right]+\left[\frac{\mathrm{V}_{\mathrm{TBA}}+\mathrm{V}_{\mathrm{SSD}}+\mathrm{V}_{\mathrm{GVC}}}{3}\right]}{2}
$$

This model is similar to the model used to assess the nutrient cycling function in that it incorporates most of the same indicators of living and dead organic matter. The living tree, understory, and ground cover components $\left(\mathrm{V}_{\mathrm{TBA}}, \mathrm{V}_{\mathrm{SSD}}\right.$, and $\mathrm{V}_{\mathrm{GVC}}$ ) represent primarily organic production, indicating 
that materials will be available for export in the future. The dead organic fraction represents the principal sources of exported material, represented by litter, snags, woody debris, and accumulation of the $\mathrm{O}$ horizon $\left(\mathrm{V}_{\text {LITTER, }}\right.$ $\mathrm{V}_{\mathrm{SNAG}}, \mathrm{V}_{\mathrm{WD}}$, and $\mathrm{V}_{\mathrm{OHOR}}$ ).

This model differs from the nutrient cycling model in that materials stored in the soil are not included because of their relative immobility, and an export mechanism is a required component of this model. The export mechanism is flooding, and it is incorporated in the model as the change in flood frequency $\left(\mathrm{V}_{\mathrm{FREQ}}\right)$ observed or anticipated based on the effects of a specific project or change in land management. This model also includes litter as a component of the dead organic fraction, despite the fact that it is a highly seasonal functional indicator that is difficult to estimate reliably, and therefore is not included in other models where it may seem appropriate. It is included in this model because it represents the most mobile organic material in the wetland, and because it may be the only component that is present in young or recently restored systems. If users of this guidebook determine that litter cannot be estimated reliably in the wetland being assessed (for example, if field work in two areas being compared will occur during different seasons), then litter can be removed from the model equation.

\section{Function 5: Maintain Plant Communities}

\section{Definition and applicability}

This function is defined as the capacity of a wetland to provide the environment necessary for native plant community development and maintenance. In assessing this function, one must consider both the extant plant community as an indication of current conditions and the physical factors that determine whether or not a characteristic plant community is likely to be maintained in the future. This function is assessed in the following subclasses in the alluvial valleys of East Texas:

- Low-gradient riverine.

- Mid-gradient riverine.

- Connected depression. 


\section{Rationale for selecting the function}

The ability to maintain a characteristic plant community is important because of the intrinsic value of the plant community and the many attributes and processes of wetlands that are influenced by the plant community. For example, primary productivity, nutrient cycling, and the ability to provide a variety of habitats necessary to maintain local and regional diversity of animals are directly influenced by the plant community (Harris and Gosselink 1990). In addition, the plant community of a riverconnected wetland influences the quality of the physical habitat, nutrient status, and biological diversity of downstream systems.

\section{Characteristics and processes that influence the function}

Numerous studies describe the environmental factors that influence the occurrence and characteristics of plant communities in wetlands (Robertson et al. 1978, 1984; Wharton et al. 1982; Robertson 1992; Smith 1996; Messina and Conner 1997; Hodges 1997; Klimas et al. 2009). Hydrologic regime is usually cited as the principal factor controlling plant community attributes. Consequently, this factor is a fundamental consideration in the basic hydrogeomorphic classification scheme employed in this document. Soil characteristics also are significant determinants of plant community composition. In addition to physical factors, system dynamics and disturbance history are important in determining the condition of a wetland plant community at any particular time. These include past land use, timber harvest history, hydrologic changes, sediment deposition, and events such as storms, fire, beaver activity, insect outbreaks, and disease. Clearly, some characteristics of plant communities within a particular wetland subclass may be determined by factors too subtle or variable to be assessed using rapid field estimates. Therefore, this function is assessed primarily by considering the degree to which the existing plant community structure and composition are appropriate to site conditions and the expected stage of maturity for the site. Secondarily, soil and hydrologic conditions are assessed to determine if fundamental requirements are met to maintain wetland conditions appropriate to the geomorphic setting.

\section{General form of the assessment model}

The model for assessing the Maintain Plant Communities function includes the following assessment variables, which are discussed in greater detail in Chapter 6: 


$$
\begin{aligned}
\mathrm{V}_{\text {TBA }} & =\text { tree basal area } \\
\mathrm{V}_{\text {TDEN }} & =\text { tree density } \\
\mathrm{V}_{\text {COMP }} & =\text { composition of tallest woody stratum } \\
\mathrm{V}_{\text {SOIL }} & =\text { soil integrity } \\
\mathrm{V}_{\text {DUR }} & =\text { change in growing season flood duration } \\
V_{\text {POND }} & =\text { microdepressional ponding }
\end{aligned}
$$

The model can be expressed in a general form:

$$
\mathrm{FCI}=\left\{\left[\frac{\left[\frac{\left(\mathrm{V}_{\mathrm{TBA}}+\mathrm{V}_{\mathrm{TDEN}}\right)}{2}+\mathrm{V}_{\mathrm{COMP}}\right]}{2}\right\} \times\left[\frac{\left(\mathrm{V}_{\mathrm{SOIL}}+\mathrm{V}_{\mathrm{DUR}}+\mathrm{V}_{\mathrm{POND}}\right)}{3}\right]\right]^{1 / 2}
$$

The first expression of the model has two components. One component describes the structure of the overstory stratum of the plant community in terms of tree basal area and density ( $\mathrm{V}_{\text {TBA }}$ and $\left.\mathrm{V}_{\text {TDENS }}\right)$. Together these indicate whether the stand has a structure typical of a mature forest appropriate to the hydrogeomorphic setting. The second term of the expression considers plant species composition of the dominant stratum ( $\mathrm{V}_{\mathrm{COMP}}$ ), which will be the overstory in most instances, but which may be the shrub or ground cover layers in communities that are in earlier (or arrested) stages of development. This allows recognition of the faster recovery trajectory likely to take place in planted restoration sites (versus abandoned fields). It also accounts for sites that have been invaded by species capable of significantly delaying or preventing normal stand development, in particular non-native species such as Chinese tallow.

The second expression of the model considers several factors that may be crucial to plant community maintenance under certain conditions. $\mathrm{V}_{\text {SoIL }}$ is a simple comparison of the soil on the site to the mapped or predicted soil type for the area and geomorphic setting. The VsoiL variable allows recognition of sites where the native soils have been replaced or buried by materials inappropriate to the site or where the native soils have been damaged significantly, as by compaction. The $V_{\text {DUR }}$ variable allows recognition of changes in growing season flood duration in sites where project impacts or land use changes have occurred or are anticipated that will extend or reduce the amount of time that substrates are flooded during the growing season. These changes can have significant effects on 
plant community structure and composition. The $V_{\text {POND }}$ variable focuses

on a specific aspect of site alteration - the removal of microtopography and related ponding of water on flats and riverine wetlands. As described previously, ponding of precipitation is a crucial mechanism for maintaining wetland character in many wetlands in the alluvial valleys of East Texas. Variations in flood frequency also influence the characteristics of wetland plant communities within the region, but this relationship is considered separately as a basic classification factor.

\section{Function 6: Provide Habitat for Fish and Wildlife}

\section{Definition and applicability}

This function is defined as the ability of a wetland to support the fish and wildlife species that typically use wetlands during some part of their life cycles. It is assessed in the following subclasses in the alluvial valleys of East Texas:

- Low-gradient riverine.

- Mid-gradient riverine.

- Connected depression.

\section{Rationale for selecting the function}

Terrestrial, semiaquatic, and aquatic animals use wetlands extensively. Maintenance of this function ensures habitat for a diversity of vertebrate organisms, contributes to secondary production, and maintains complex trophic interactions. Habitat functions span a range of temporal and spatial scales, and include the provision of refugia and habitat for wideranging or migratory animals as well as highly specialized habitats for endemic species. However, most wildlife and fish species found in wetlands of the alluvial valleys of East Texas depend on certain aspects of wetland structure and dynamics, such as periodic flooding or ponding of water, vegetation characteristics, and proximity to other habitats.

\section{Characteristics and processes that influence the function}

The quality and availability of habitats for fish and wildlife species in wetlands of the alluvial valleys of East Texas are dependent on a variety of factors operating at different scales. Habitat components that can be considered in a rapid field assessment include vegetation structure and composition; detrital elements; availability of water; and spatial attributes 
such as patch size and connectivity. The dependence of animals on native plant communities and their characteristic detrital components, such as snags and logs, is well-documented (Stauffer and Best 1980; Wharton et al. 1982; Harmon et al. 1986; Schoener 1986; Allen 1987; J ohnson 1987; Howard and Allen 1989; Hunter 1990; Loeb 1993). The assessment procedure used here focuses on those attributes to a large extent, with maximum habitat functionality for the widest group of animal species assumed to be present in mature, complex systems.

Hydrology also is a major factor influencing wildlife habitat quality in East Texas lowlands. A significant hydrologic component is precipitation captured in vernal pools and microdepressions. These sites are sources of surface water for various terrestrial animals, and provide reproductive habitat for invertebrates and amphibians, many of which are utilized as a food source by other animals (Wharton et al. 1982; J ohnson 1987). Ponded breeding sites without predatory fish populations are very important for some species of salamanders and frogs (J ohnson 1987). While wetlands with temporary ponding of precipitation are important to many species precisely because they provide an environment that is isolated from many aquatic predators, large floodplain wetlands that are periodically streamconnected also provide vital habitat for some species. Wharton et al. (1982) in an overview of fish use of bottomland hardwoods in the Piedmont and eastern Coastal Plain stated that at least 20 families comprising 53 species of fish use various portions of the floodplain for foraging and spawning. Baker and Killgore (1994) reported similar results from the Cache River drainage in Arkansas, where they found that most fish species exploit floodplain habitats at some time during the year, many for spawning and rearing.

The spatial and temporal distribution of habitat components on the landscape scale is an important aspect of wildlife habitat quality. Typical concerns include the size of the habitat "patch," surrounding land uses, connections to other systems, and the scale and periodicity of disturbance (Hunter 1990; Morrison et al. 1992). Studies of fragmentation and patch size effects on birds (Thompson et al. 1992; Welsh and Healy 1993; Robinson et al. 1995; Sallabanks et al. 1998) indicate that as the mix of feeding habitats (agricultural and suburban lands) and breeding habitats (forests and grasslands) increases, predators and nest parasites become increasingly successful, even if large blocks of habitat remain. Thus, in more open landscapes, block sizes need to be larger than in mostly 
forested ones. Conversely, Robinson (1996) estimated that as the percentage of the landscape that is forested increases above 70 percent (approximately), the size of the forest blocks within that landscape becomes less significant to bird populations. In a review of this issue, Hunter et al. (2001) indicated that blocks of approximately 2500 ha are adequate in landscapes with predominantly mixed forest cover (including pine plantations). Much of East Texas meets this criterion.

In the case of the depression wetlands that typically occur as small patches within a matrix of drier sites, and where wetlands occur as narrow zones along mid-gradient streams, buffer zones (or adjacent, nonwetland habitats) are particularly important to amphibians and reptiles that spend parts of their life cycles outside the wetland (McWilliams and Bachman 1988; Burke and Gibbons 1995; Semlitsch and Bodie 1998; Boyd 2001; Gibbons and Buhlmann 2001; Gibbons 2003). Recommendations for functional buffer widths are highly variable depending on the species involved and the types of activities they pursue outside the wetland. Semlitsch and J ensen (2001) stressed that wetlands and adjacent uplands together are essential habitat for many semiaquatic species. Boyd (2001) determined that a buffer approximately $30 \mathrm{~m}$ wide is required to "provide some protection" to a large percentage of wetland-dependant species in Massachusetts, but does not meet the needs of a variety of animals that range well beyond that limit. Studies in other regions also have determined that much wider buffers may be required to accommodate the nesting or hibernation needs of many species or to provide habitat for animals that spend the majority of their time in upland habitats but must return to water to breed (Gibbons 2003). Recommended buffer widths for reptile and amphibian conservation range from $275 \mathrm{~m}$ for Carolina bay wetlands (Burke and Gibbons 1995) to $165 \mathrm{~m}$ in forest wetlands of Missouri (Semlitsch 1998) and $250 \mathrm{~m}$ in forest wetlands of central Tennessee (Miller 1995; Bailey and Bailey 2000).

The characteristics of the buffer zones (or adjacent habitats) determine whether they can be used effectively by the semiaquatic species that depend on small wetlands of depressions and along small and moderate-size streams. Because the buffer area is used as habitat for various activities, it should be dominated by native vegetation and be without impediments to movement, such as busy roads, dense logging debris, or structures. Nonforest vegetation (such as old fields) in a naturally forested landscape can also represent a significant impediment to animal movement, 
particularly for emigrating juvenile amphibians (Rothermel and Semlitsch 2002).

\section{General form of the assessment model}

The model for assessing the Fish and Wildlife Habitat function includes the following assessment variables, which are discussed in greater detail in Chapter 6:

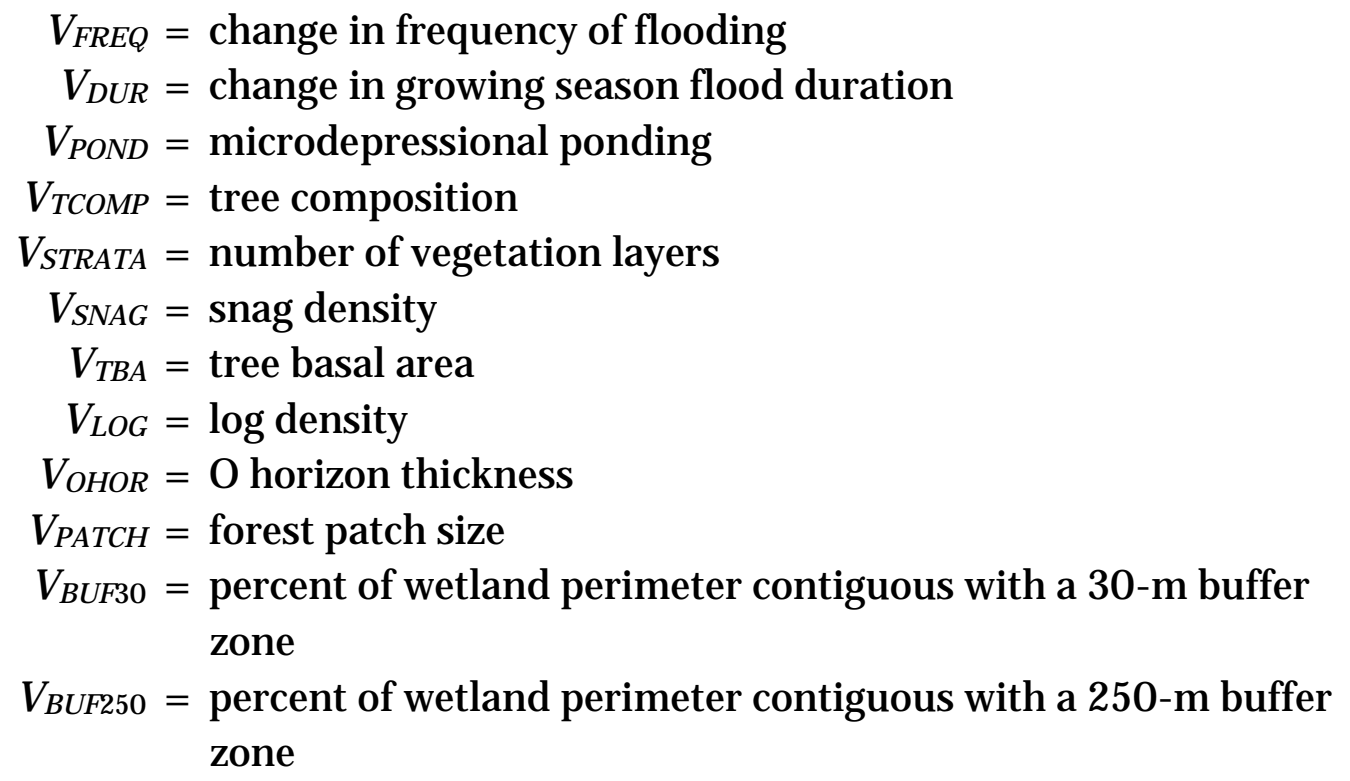

The model can be expressed in a general form:

$$
\mathrm{FCI}=\left\{\begin{array}{c}
{\left[\frac{\left(\mathrm{V}_{\mathrm{FREQ}}+\mathrm{V}_{\mathrm{DUR}}+\mathrm{V}_{\mathrm{POND}}\right)}{3}\right] \times\left[\frac{\left(\mathrm{V}_{\mathrm{TCOMP}}+\mathrm{V}_{\mathrm{STRATA}}+\mathrm{V}_{\mathrm{SNAG}}+\mathrm{V}_{\mathrm{TBA}}\right)}{4}\right]} \\
\times\left[\frac{\left(\mathrm{V}_{\mathrm{LOG}}+\mathrm{V}_{\mathrm{OHOR}}\right)}{2}\right] \times\left[\begin{array}{c}
\text { Landscape } \\
\text { Variables }
\end{array}\right]
\end{array}\right\}^{1 / 4}
$$

The expressions within the model reflect the major habitat components described. The first expression concerns hydrology, and includes indicators of both seasonal inundation, which allows river access by aquatic organisms ( $\mathrm{V}_{\mathrm{DUR}}$ and $\mathrm{V}_{\mathrm{FREQ}}$ ) as well as the periodic occurrence of temporary, isolated aquatic conditions ( $\mathrm{V}_{\mathrm{POND}}$ ). The second expression includes four indicators of forest structure and diversity: the basal area of overstory (canopy) trees ( $\left.\mathrm{V}_{\mathrm{TBA}}\right)$, overstory tree species composition ( $\left.\mathrm{V}_{\mathrm{TCOMP}}\right)$, snag density ( $\mathrm{V}_{\mathrm{SNAG}}$ ) and a measure of structural complexity $\left(\mathrm{V}_{\text {STRATA }}\right)$. Together these variables reflect a variety of conditions of 
importance to wildlife, including forest maturity and complexity and the availability of food and cover. Where the exotic species Chinese tallow dominates the overstory, the overall wildlife habitat functional capacity index is reduced, reflecting the documented detrimental effects of this species on bird communities (Barrow and Renne 2001). Habitat structure for animals associated with detrital components is indicated by two variables: the volume of logs per unit area $\left(\mathrm{V}_{\mathrm{LOG}}\right)$ and the thickness of the O horizon ( $\left.\mathrm{V}_{\mathrm{OHOR}}\right)$. Note that the litter layer, which is important to some species, is not included in the model due to its seasonality. Instead, the $\mathrm{O}$ horizon is used as an indicator of litter accumulation, since it is a direct result of litter decay.

The final expression (Landscape Variables) may incorporate different terms, depending on the subclass being assessed. In the low-gradient riverine subclass, a single variable $\left(\mathrm{V}_{\mathrm{PATCH}}\right)$ is used to represent the importance of large blocks of contiguous forest in systems that historically included extensive hardwood wetlands. This focus is adopted to reflect regional and continental concerns about forest interior birds, as well as other animals adversely affected by habitat fragmentation. For the depression and mid-gradient riverine subclasses, the assessment of landscape characteristics focuses on the adequacy of buffer zones adjacent to the wetland, particularly as they influence reptiles and amphibians. The expression incorporates consideration of a 30-m "general-use" buffer zone ( $\mathrm{V}_{\text {BUF30 }}$ ) as well as a 250-m buffer zone $\left(\mathrm{V}_{\text {BUF250 }}\right.$ ) required to meet the specialized habitat requirements of many species. 


\section{Model Applicability and Reference Data}

The assessment models described in Chapter 4 are applied to individual wetland subclasses in different ways. For example, the Export Organic Carbon function is assessed only for wetlands in the Riverine and Connected Depression subclasses, where flooding provides a mechanism for export to aquatic systems. It is not assessed in the Unconnected Depression subclass, which has no export mechanism. Similarly, some variables can be deleted from the assessment models for depression subclasses if they cannot be consistently evaluated. Specifically, ground vegetation cover $\left(\mathrm{V}_{\mathrm{GVC}}\right)$, litter cover $\left(\mathrm{V}_{\mathrm{LITTER}}\right)$, woody debris and logs $\left(\mathrm{V}_{\mathrm{WD}}\right.$ and $\left.\mathrm{V}_{\mathrm{LOG}}\right)$, and thickness of the $\mathrm{O}$ and $\mathrm{A}$ horizons ( $\mathrm{V}_{\mathrm{OHOR}}$ and $\left.\mathrm{V}_{\mathrm{AHOR}}\right)$ may be difficult to assess in depressions that are inundated. Modified versions of the models applicable to the depression subclasses are provided for use in those situations. The modified models are likely to be less sensitive than the full versions, but they are complete enough to be used when necessary.

The reference data collected for each subclass has been independently summarized to scale the applicable models. For each subclass, the six potential functions available for assessment are listed, and the applicability of the assessment model is described. The model is presented as described in Chapter 4 if it is applicable in its general and complete form; an alternative version is presented for use in situations where some variables cannot be consistently assessed; and the function is identified as Not Assessed in cases where the wetland subclass does not perform the function as described in Chapter 4, or where it cannot be assessed with the methods and models available for rapid field assessment. For each wetland subclass, functional capacity subindex curves are presented for every assessment variable used in the applicable assessment models. The subindex curves were constructed based primarily on the field data; in cases where the field data were not definitive, the subindex curves were constructed to be as consistent as possible with those previously published for the same subclasses in the nearby coastal plain region of Arkansas (Klimas et al. 2006).

Flood frequency and duration subindex curves are not based on field data, but rather are specifically designed to be used in situations where a project impact or change in land use is being assessed, and the without-project 
condition is the reference condition. Similarly, the assessment of spatial relationships (buffer widths and patch size) are based on published literature and the criteria established in previous HGM guidebooks for portions of the Lower Mississippi Valley and for the West Gulf Coastal Plain region of Arkansas.

\section{Subclass: Low-Gradient Riverine}

All functions are assessed for this subclass using the general form of each assessment model presented in Chapter 4 as follows. Figure 10 illustrates the relationship between the variable metrics and the subindex for each of the assessment variables based on the low-gradient riverine reference data.

a. Detain Floodwater.

$$
\mathrm{FCI}=\mathrm{V}_{\mathrm{FREQ}} \times\left[\frac{\left(\mathrm{V}_{\mathrm{LOG}}+\mathrm{V}_{\mathrm{GVC}}+\mathrm{V}_{\mathrm{SSD}}+\mathrm{V}_{\mathrm{TDEN}}\right)}{4}\right]
$$

b. Detain Precipitation.

$$
\mathrm{FCI}=\frac{\left[\mathrm{V}_{\mathrm{POND}}+\frac{\left(\mathrm{V}_{\mathrm{OHOR}}+\mathrm{V}_{\mathrm{LITTR}}\right)}{2}\right]}{2}
$$

c. Cycle Nutrients.

$$
\mathrm{FCI}=\frac{\left[\frac{\left(\mathrm{V}_{\mathrm{TBA}}+\mathrm{V}_{\mathrm{SSD}}+\mathrm{V}_{\mathrm{GVC}}\right)}{3}+\frac{\left(\mathrm{V}_{\mathrm{OHOR}}+\mathrm{V}_{\mathrm{AHOR}}+\mathrm{V}_{\mathrm{WD}}+\mathrm{V}_{\mathrm{SNAG}}\right)}{4}\right]}{2}
$$

d. Export Organic Carbon.

$$
\mathrm{FCI}=\mathrm{V}_{\mathrm{FREQ}} \times \frac{\left[\frac{\left(\mathrm{V}_{\mathrm{LITTR}}+\mathrm{V}_{\mathrm{OHOR}}+\mathrm{V}_{\mathrm{WD}}+\mathrm{V}_{\mathrm{SNAG}}\right)}{4}\right]+\left[\frac{\left.\mathrm{V}_{\mathrm{TBA}}+\mathrm{V}_{\mathrm{SSD}}+\mathrm{V}_{\mathrm{GVC}}\right]}{3}\right]}{2}
$$

e. Maintain Plant Communities.

$$
\mathrm{FCI}=\left\{\int \frac{\left[\frac{\left(\mathrm{V}_{\mathrm{TBA}}+\mathrm{V}_{\mathrm{TDEN}}\right)}{2}+\mathrm{V}_{\text {COMP }}\right]}{2}\right\} \times\left[\frac{\left(\mathrm{V}_{\mathrm{SOIL}}+\mathrm{V}_{\mathrm{DUR}}+\mathrm{V}_{\mathrm{POND}}\right)}{3}\right]^{1 / 2}
$$


f. Provide Habitat for Fish and Wildlife.

$$
\mathrm{FCI}=\left\{\begin{array}{c}
{\left[\left(\frac{\left.\mathrm{V}_{\text {FREQ }}+\mathrm{V}_{\text {DUR }}+\mathrm{V}_{\text {POND }}\right)}{3}\right] \times\left[\frac{\left(\mathrm{V}_{\text {TCOMP }}+\mathrm{V}_{\text {STRATA }}+\mathrm{V}_{\text {SNAG }}+\mathrm{V}_{\text {TBA }}\right)}{4}\right]\right.} \\
\times\left[\frac{\left(\mathrm{V}_{\text {LOG }}+\mathrm{V}_{\text {OHOR }}\right)}{2}\right] \times \mathrm{V}_{\text {PATCH }}
\end{array}\right\}
$$

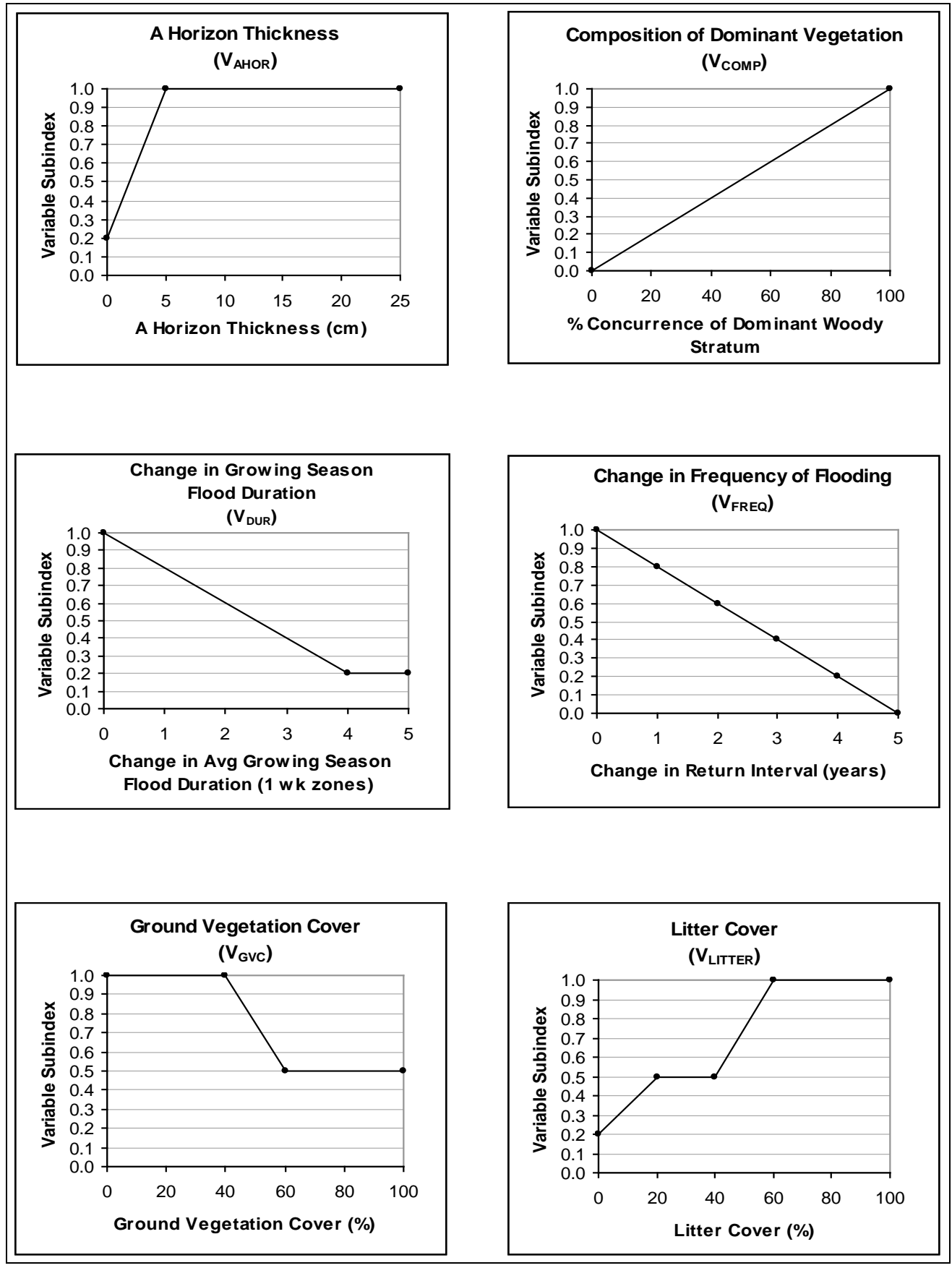

Figure 10. Subindex graphs for Low-Gradient Riverine wetlands.

(Sheet 1 of 3) 


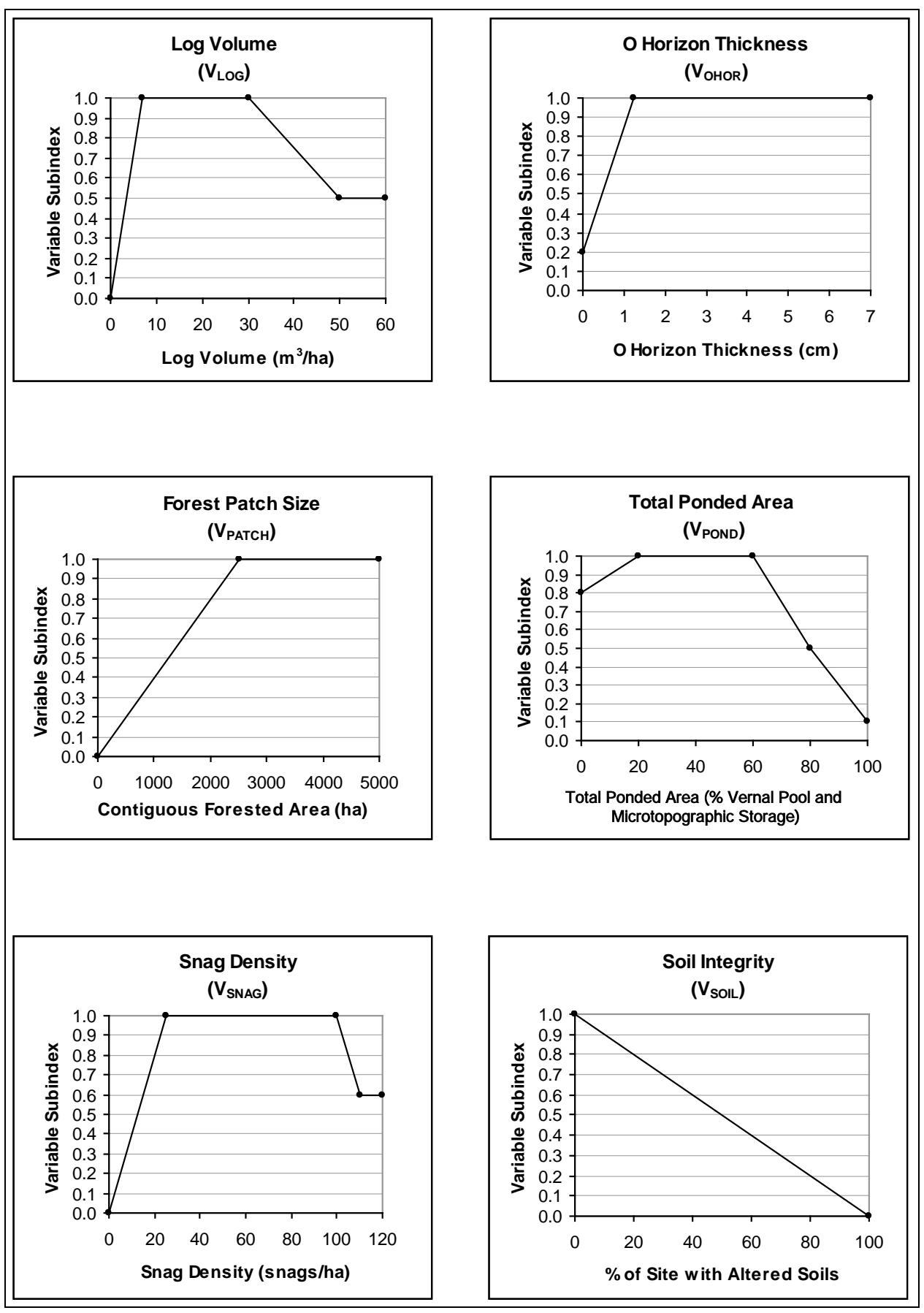

Figure 10. (Sheet 2 of 3) 


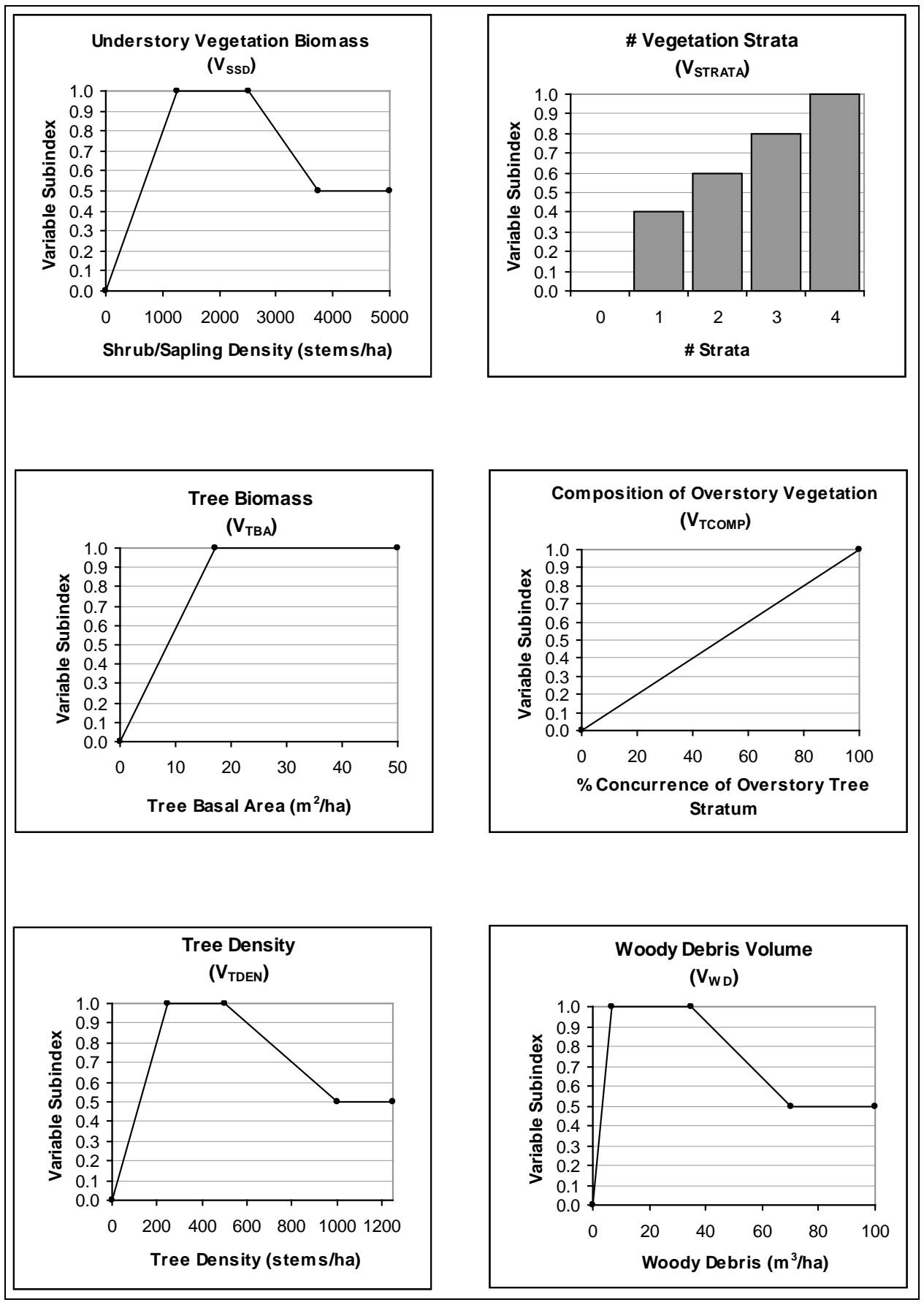

Figure 10. (Sheet 3 of 3)

\section{Subclass: Mid-Gradient Riverine}

All functions are assessed for this subclass using the general form of each assessment model presented in Chapter 4. Figure 11 illustrates the relationship between the variable metrics and the subindex for each of the assessment variables based on the mid-gradient riverine reference data. 
a. Detain Floodwater

$$
\mathrm{FCI}=\mathrm{V}_{\mathrm{FREQ}} \times\left[\frac{\left(\mathrm{V}_{\mathrm{LOG}}+\mathrm{V}_{\mathrm{GVC}}+\mathrm{V}_{\mathrm{SSD}}+\mathrm{V}_{\mathrm{TDEN}}\right)}{4}\right]
$$

b. Detain Precipitation

$$
\mathrm{FCI}=\frac{\left[\mathrm{V}_{\mathrm{POND}}+\frac{\left(\mathrm{V}_{\mathrm{OHOR}}+\mathrm{V}_{\mathrm{LITTR}}\right)}{2}\right]}{2}
$$

c. Cycle Nutrients

$$
\mathrm{FCI}=\frac{\left[\frac{\left(\mathrm{V}_{\mathrm{TBA}}+\mathrm{V}_{\mathrm{SSD}}+\mathrm{V}_{\mathrm{GVC}}\right)}{3}+\frac{\left(\mathrm{V}_{\mathrm{OHOR}}+\mathrm{V}_{\mathrm{AHOR}}+\mathrm{V}_{\mathrm{WD}}+\mathrm{V}_{\mathrm{SNAG}}\right)}{4}\right]}{2}
$$

d. Export Organic Carbon

$$
\mathrm{FCI}=\mathrm{V}_{\mathrm{FREQ}} \times \frac{\left[\frac{\left(\mathrm{V}_{\mathrm{LTTTR}}+\mathrm{V}_{\mathrm{OHOR}}+\mathrm{V}_{\mathrm{WD}}+\mathrm{V}_{\mathrm{SNAG}}\right)}{4}\right]+\left[\frac{\mathrm{V}_{\mathrm{TBA}}+\mathrm{V}_{\mathrm{SSD}}+\mathrm{V}_{\mathrm{GVC}}}{3}\right]}{2}
$$

e. Maintain Plant Communities

$$
\left.\mathrm{FCI}=\left\{\int \frac{\left.\frac{\left(\mathrm{V}_{\mathrm{TBA}}+\mathrm{V}_{\mathrm{TDEN}}\right)}{2}+\mathrm{V}_{\mathrm{COMP}}\right]}{2}\right\} \times\left[\frac{\left(\mathrm{V}_{\mathrm{SOIL}}+\mathrm{V}_{\mathrm{DUR}}+\mathrm{V}_{\mathrm{POND}}\right)}{3}\right]\right]^{1 / 2}
$$

f. Provide Habitat for Fish and Wildlife

$$
\mathrm{FCI}=\left\{\begin{array}{c}
{\left[\frac{\left(\mathrm{V}_{\mathrm{FREQ}}+\mathrm{V}_{\text {DUR }}+\mathrm{V}_{\text {POND }}\right)}{3}\right] \times\left[\frac{\left(\mathrm{V}_{\text {TCOMP }}+\mathrm{V}_{\text {STRATA }}+\mathrm{V}_{\mathrm{SNAG}}+\mathrm{V}_{\mathrm{TBA}}\right)}{4}\right]} \\
\times\left[\frac{\left(\mathrm{V}_{\text {LOG }}+\mathrm{V}_{\text {OHOR }}\right)}{2}\right] \times\left[\frac{\left(\mathrm{V}_{\text {BUF 30 }}+\mathrm{V}_{\text {BUF 250 }}\right)}{2}\right]
\end{array}\right]^{1 / 4}
$$




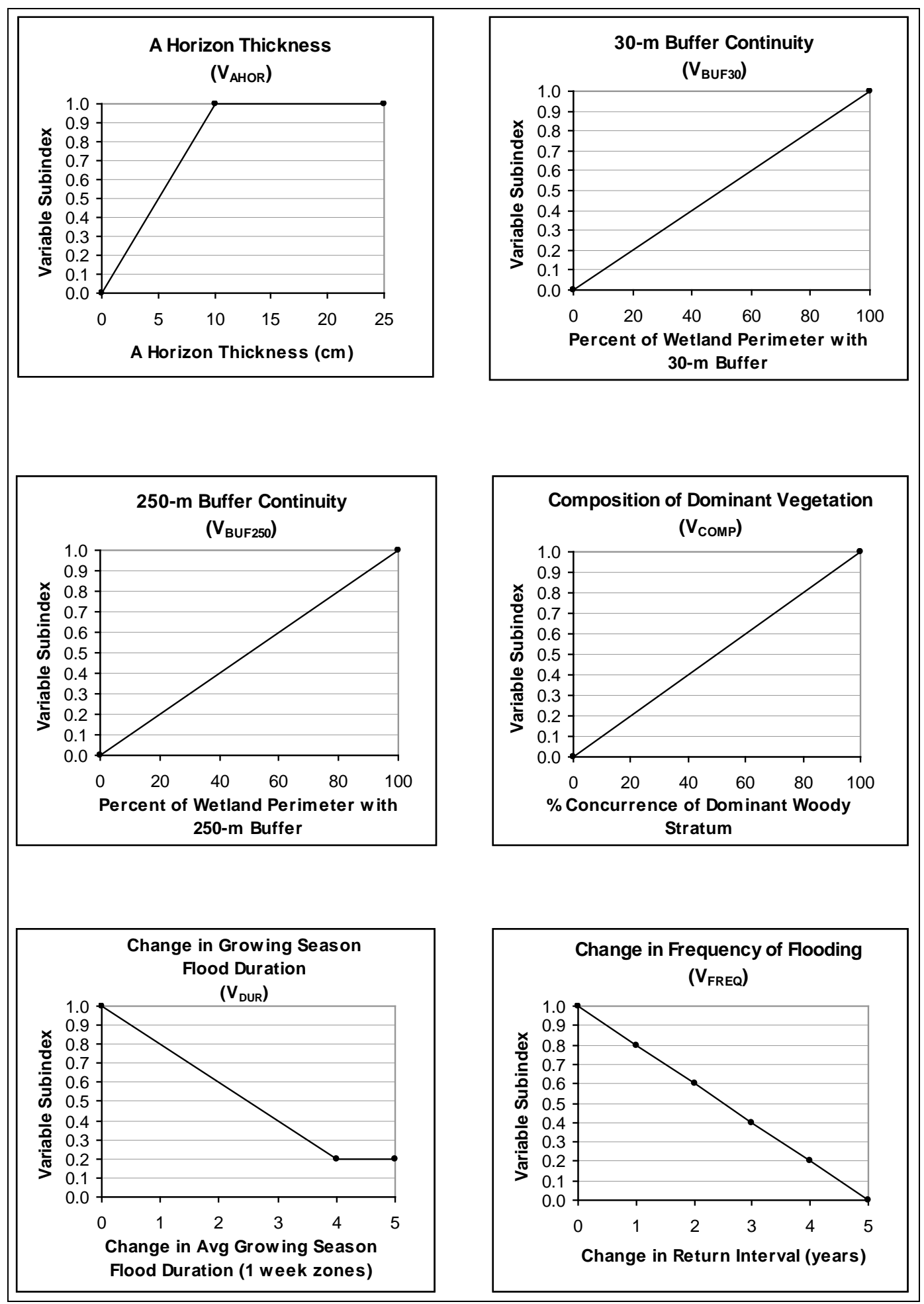

Figure11. Subindex graphs for Mid-Gradient Riverine Wetlands.

(Sheet 1 of 4 ) 

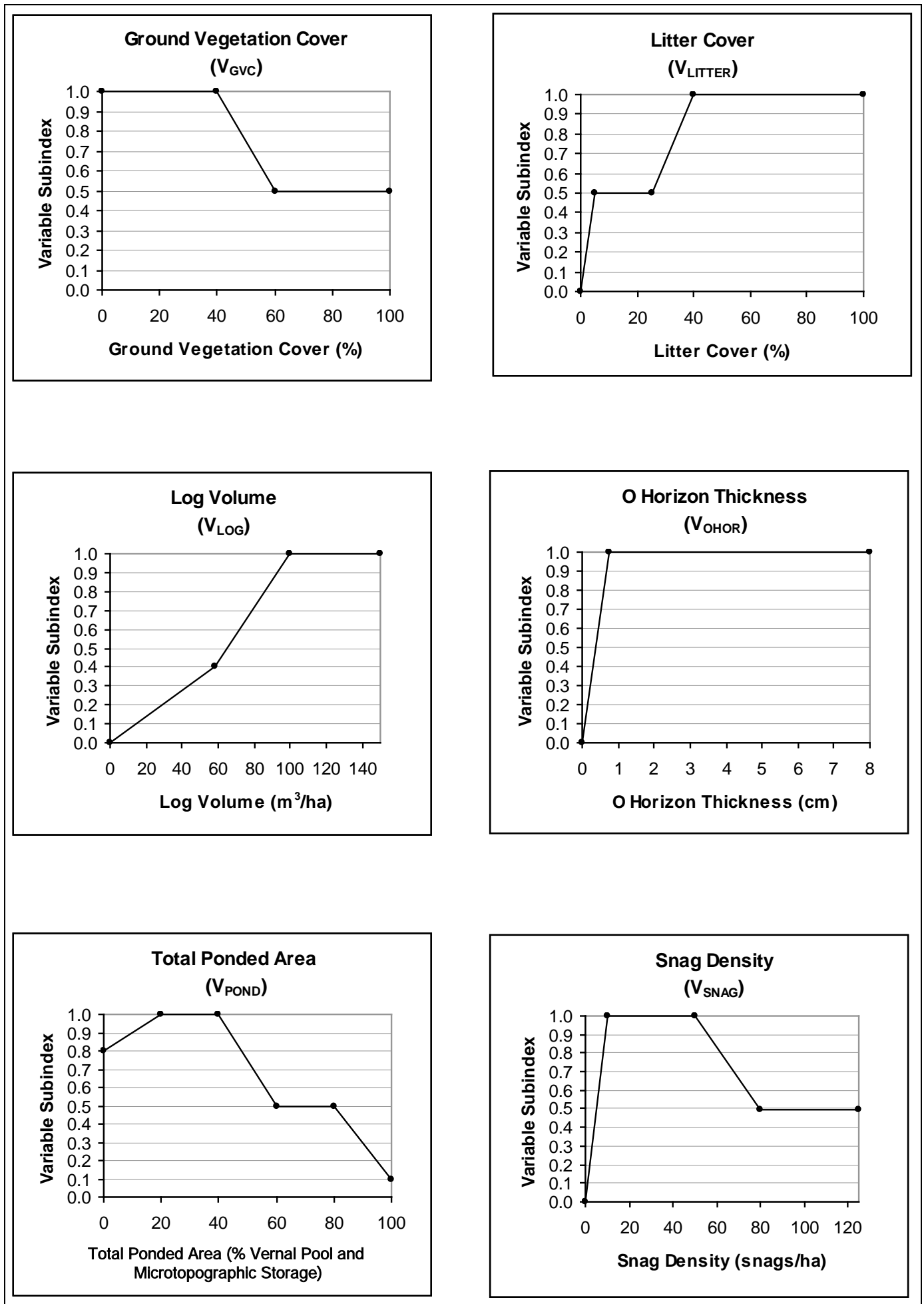

Figure 11. (Sheet 2 of 4) 

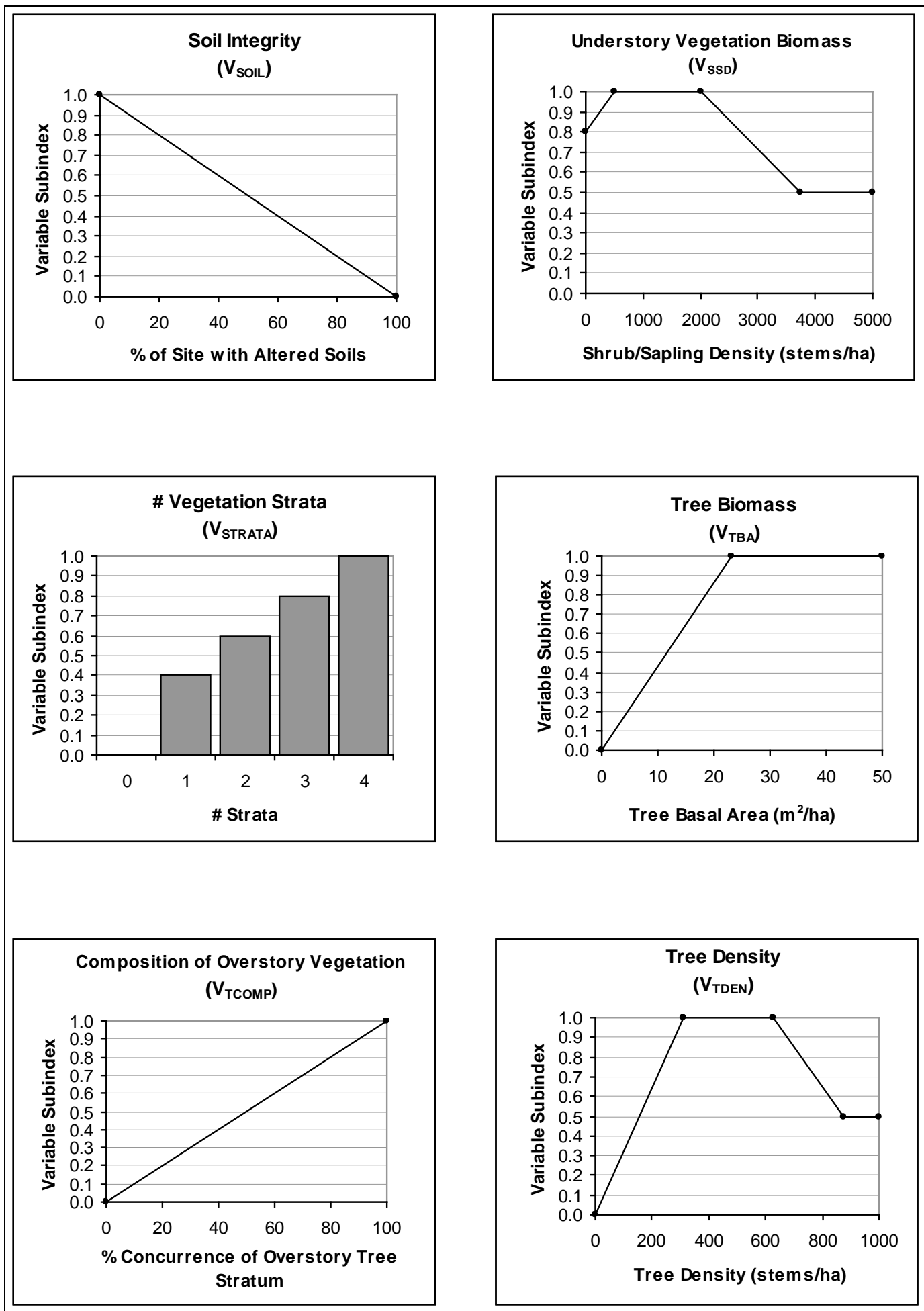

Figure 11. (Sheet 3 of 4) 


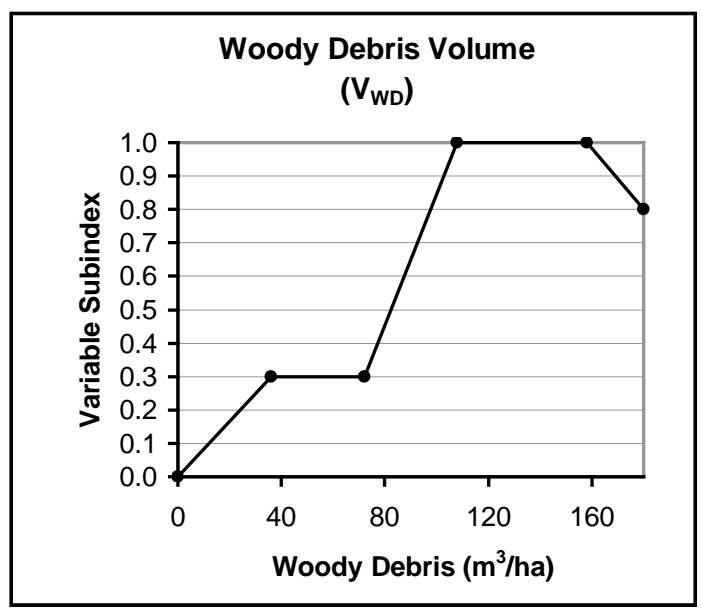

Figure 11. (Sheet 4 of 4 )

\section{Subclass: Connected Depression}

Five functions are assessed for this subclass as follows. Some of the models have been modified from the general model form presented in Chapter 4. Figure 12 illustrates the relationship between the variable metrics and the subindex for each of the assessment variables based on the connected depression reference data.

a. Detain Floodwater.

$$
\mathrm{FCI}=\mathrm{V}_{\mathrm{FREQ}} \times\left[\frac{\left(\mathrm{V}_{\mathrm{LOG}}+\mathrm{V}_{\mathrm{GVC}}+\mathrm{V}_{\mathrm{SSD}}+\mathrm{V}_{\mathrm{TDEN}}\right)}{4}\right]
$$

Applicable in the following alternate form when inundation prevents observation of ground-level features:

$$
\mathrm{FCI}=\mathrm{V}_{\mathrm{FREQ}} \times\left[\frac{\left(\mathrm{V}_{\mathrm{SSD}}+\mathrm{V}_{\mathrm{TDEN}}\right)}{2}\right]
$$

b. Detain Precipitation. Not assessed.

c. Cycle Nutrients. Applicable in the following modified form:

$$
\mathrm{FCI}=\frac{\left[\frac{\left(\mathrm{V}_{\mathrm{TBA}}+\mathrm{V}_{\mathrm{SSD}}+\mathrm{V}_{\mathrm{GVC}}\right)}{3}+\frac{\left(\mathrm{V}_{\mathrm{OHOR}}+\mathrm{V}_{\mathrm{AHOR}}+\mathrm{V}_{\mathrm{WD}}+\mathrm{V}_{\mathrm{SNAG}}\right)}{4}\right]}{2}
$$


Applicable in the following alternate form when inundation prevents observation of ground-level features:

$$
\mathrm{FCI}=\frac{\left(\mathrm{V}_{\mathrm{TBA}}+\mathrm{V}_{\mathrm{SSD}}+\mathrm{V}_{\mathrm{SNAG}}\right)}{3}
$$

d. Export Organic Carbon. Applicable in the following modified form:

$$
\mathrm{FCI}=\mathrm{V}_{\mathrm{FREQ}} \times \frac{\left[\frac{\left(\mathrm{V}_{\mathrm{LTTTR}}+\mathrm{V}_{\mathrm{OHOR}}+\mathrm{V}_{\mathrm{WD}}+\mathrm{V}_{\mathrm{SNAG}}\right)}{4}\right]+\left[\frac{\mathrm{V}_{\mathrm{TBA}}+\mathrm{V}_{\mathrm{SSD}}+\mathrm{V}_{\mathrm{GVC}}}{3}\right]}{2}
$$

Applicable in the following alternate form when inundation prevents observation of ground-level features:

$$
\mathrm{FCI}=\mathrm{V}_{\mathrm{FREQ}} \times\left[\frac{\left(\mathrm{V}_{\mathrm{TBA}}+\mathrm{V}_{\mathrm{SSD}}+\mathrm{V}_{\mathrm{SNAG}}\right)}{3}\right]
$$

e. Maintain Plant Communities. Applicable in the following modified form:

$$
\mathrm{FCI}=\left\{\left[\frac{\left[\frac{\left(\mathrm{V}_{\mathrm{TBA}}+\mathrm{V}_{\mathrm{TDEN}}\right)}{2}+\mathrm{V}_{\mathrm{COMP}}\right]}{2}\right\} \times\left[\frac{\mathrm{V}_{\mathrm{SOIL}}+\mathrm{V}_{\mathrm{DUR}}}{2}\right]\right]^{1 / 2}
$$

Applicable in the following alternate form when inundation prevents observation of ground-level features:

$$
\left.\mathrm{FCI}=\int\left\{\frac{\left(\frac{\left(\mathrm{V}_{\mathrm{TBA}}+\mathrm{V}_{\mathrm{TDEN}}\right)}{2}+\mathrm{V}_{\mathrm{COMP}}\right]}{2}\right\} \times \mathrm{V}_{\mathrm{DUR}}\right)^{1 / 2}
$$

f. Provide Habitat for Fish and Wildlife. Applicable in the following modified form: 


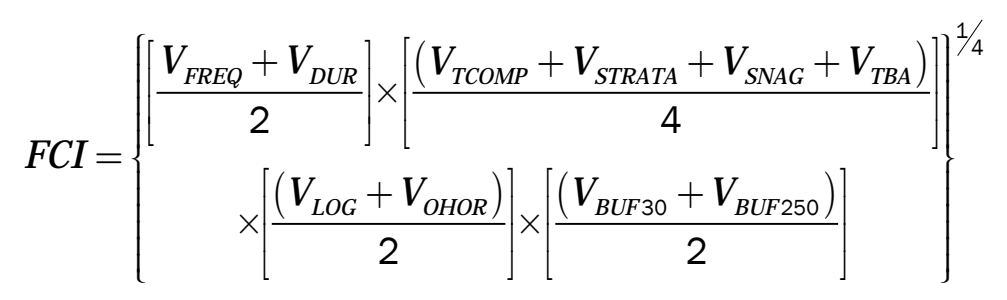

Applicable in the following alternate form when inundation prevents observation of ground-level features:

$$
\mathrm{FCI}=\left\{\begin{array}{c}
\left.\left[\frac{\mathrm{V}_{\mathrm{FREQ}}+\mathrm{V}_{\mathrm{DUR}}}{2}\right] \times\left[\frac{\left(\mathrm{V}_{\mathrm{TCOMP}}+\mathrm{V}_{\mathrm{STRATA}}+\mathrm{V}_{\mathrm{SNAG}}+\mathrm{V}_{\mathrm{TBA}}\right)}{4}\right]\right]^{1 / 3} \\
\times\left[\frac{\left(\mathrm{V}_{\mathrm{BUF} 30}+\mathrm{V}_{\mathrm{BUF} 250}\right)}{2}\right]
\end{array}\right\}
$$




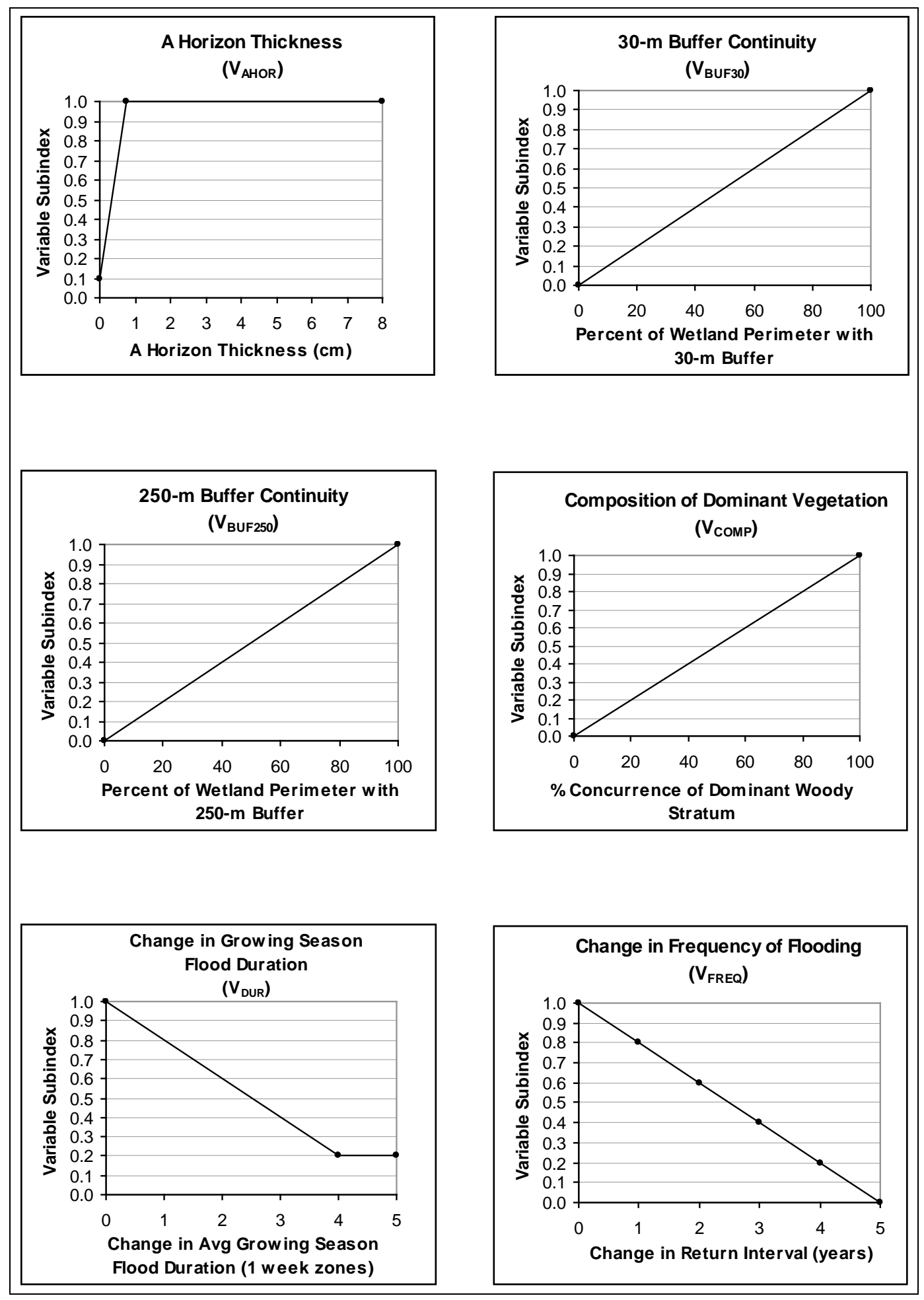

Figure 12. Subindex graphs for Connected Depression wetlands.

(Sheet 1 of 3) 

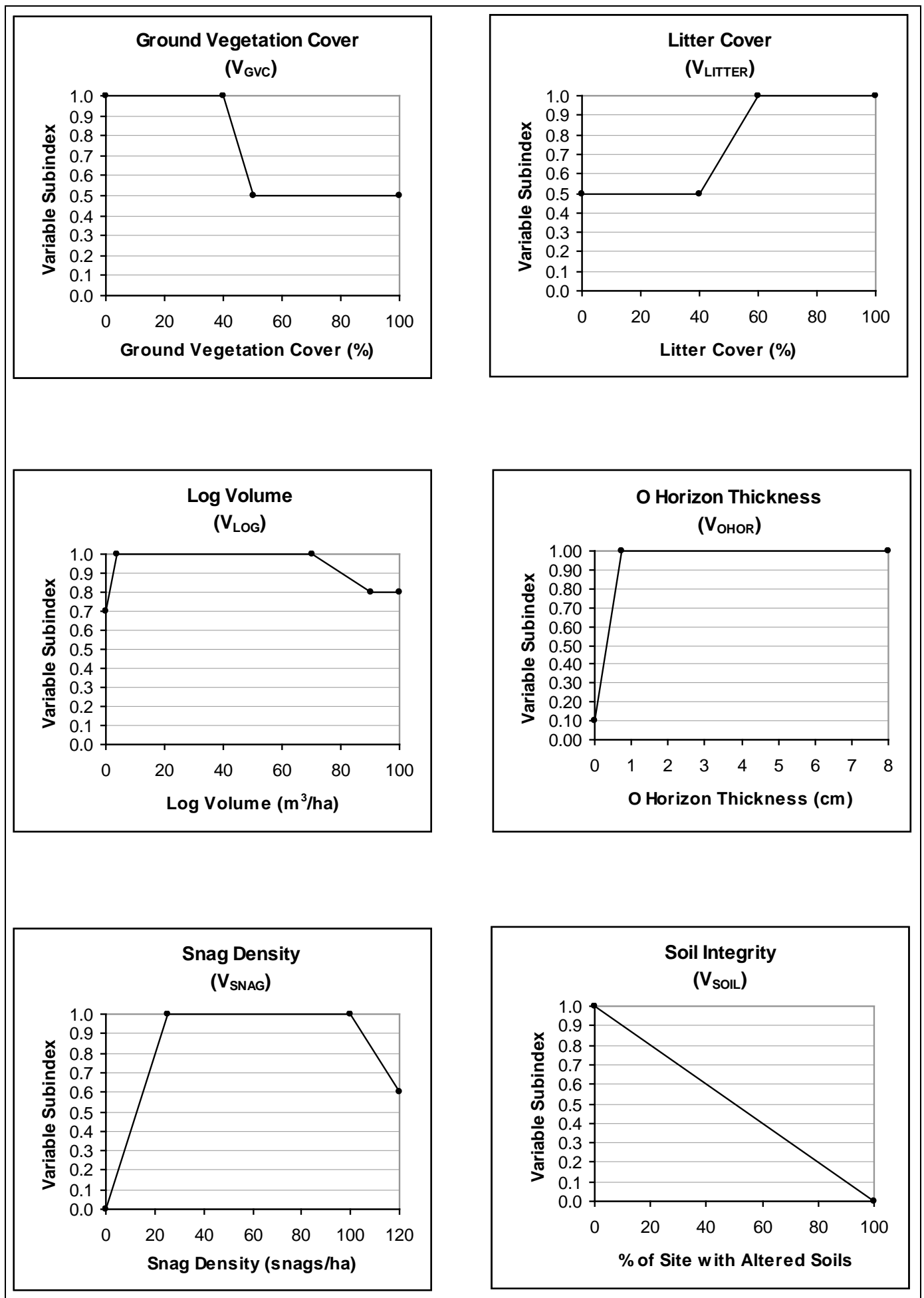

Figure 12. (Sheet 2 of 3) 


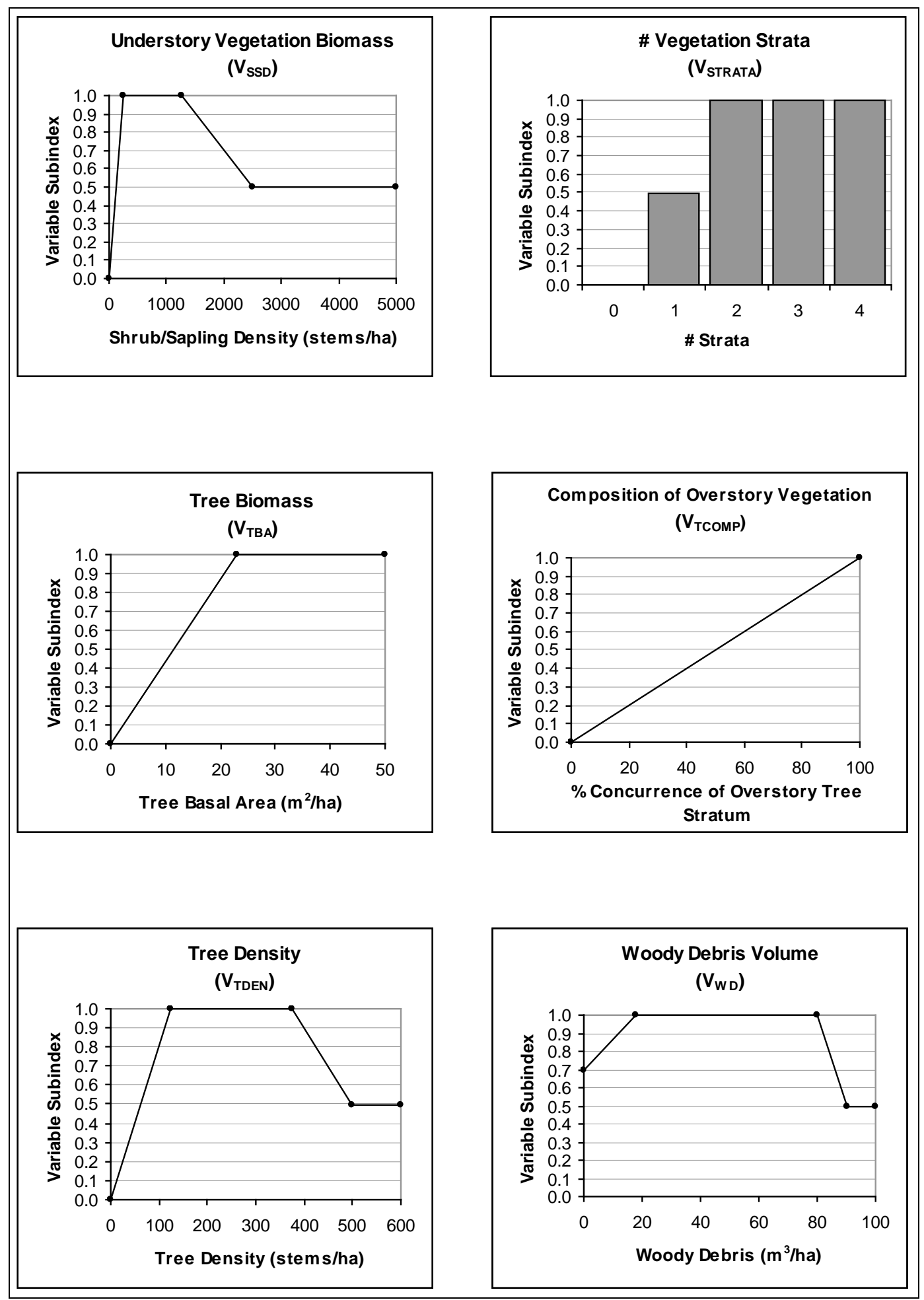

Figure 12. (Sheet 3 of 3) 


\section{Assessment Protocol}

\section{Introduction}

Previous chapters of this Regional Guidebook have provided background information on the HGM Approach, characterized regional wetland subclasses, and documented the variables, functional indices, and assessment models used to assess regional wetland subclasses in alluvial valleys of East Texas. This chapter outlines the procedures for collecting and analyzing the data required to conduct an assessment.

In most cases, permit review, restoration planning, and similar assessment applications require that pre- and post-project conditions of wetlands at the project site be compared to develop estimates of the loss or gain of function associated with the project. Both the pre- and post-project assessments should be completed at the project site before the proposed project has begun. Data for the pre-project assessment represents existing conditions at the project site, while data for the post-project assessment is normally based on a prediction of the conditions that can reasonably be expected to exist following proposed project impacts. The rationale and assumptions used to establish post-project conditions should be clearly stated.

Where the proposed project involves wetland restoration or compensatory mitigation, this guidebook can also be used to assess the functional effectiveness of the proposed actions. The final section of this chapter provides recovery trajectory curves for selected variables that may be employed in that analysis.

A series of tasks are required to assess regional wetland subclasses in alluvial valleys of East Texas using the HGM Approach:

- Document the project purpose and characteristics.

- Screen for red flags.

- Define assessment objectives and identify regional wetland subclass(es) present and assessment area boundaries.

- Collect field data.

- Analyze field data.

- Document assessment results.

- Apply assessment results. 
The following sections discuss each of these tasks in greater detail.

\section{Document the Project Purpose and Characteristics}

Data Form A1 (Site or Project Information and Assessment

Documentation, Appendix A) provides a checklist of information needed

to conduct a complete assessment, and serves as a cover sheet for all compiled assessment maps, drawings, data forms, and other information. It requires the assignment of a project name and identification of personnel involved in the assessment. Supporting information and documentation are to be attached to this form. The first step in this process is to develop a narrative explanation of the project, with supporting maps and graphics. This should include a description of the project purpose and project area features, which can include information on location, climate, surficial geology, geomorphic setting, surface and groundwater hydrology, vegetation, soils, land use, existing cultural alteration, proposed impacts, and any other characteristics and processes that have the potential to influence how wetlands at the project area perform functions. The accompanying maps and drawings should indicate the locations of the project area boundaries, jurisdictional wetlands, wetland assessment areas (WAA) (to be discussed later in this chapter), proposed impacts, roads, ditches, buildings, streams, soil types, plant communities, threatened or endangered species habitats, and other important features.

Many sources of information will be useful in characterizing a project area:

- Aerial photographs.

- Topographic maps.

- Geomorphic maps.

- County soil surveys.

- National Wetland Inventory maps.

- Flood frequency maps.

- Chapter 3 of this Regional Guidebook.

For large projects or complex landscapes, it is usually a good idea to use aerial photos, flood maps, and geomorphic information to develop a preliminary classification of wetlands for the project area and vicinity prior to going to the field. The rough wetland map can then be taken to the field to refine and revise the identification of wetland subclasses. 
Attach the completed Project Description and supporting materials to Data Form A1.

\section{Screen for Red Flags}

Red flags are features in the vicinity of the project area to which special recognition or protection has been assigned on the basis of objective criteria (Table 6). Many red flag features, based on national criteria or programs, are similar from region to region. Other red flag features are based on regional or local criteria. Screening for red flag features determines if the wetlands or other natural resources around the project area require special consideration or attention that may preempt or postpone conducting a wetland assessment. For example, if a proposed project has the potential to adversely affect threatened or endangered species, an assessment may be unnecessary since the project may be denied or modified based on the impacts to the protected species alone.

\section{Define Assessment Objectives and Identify Regional Wetland Subclass(es) Present and Assessment Area Boundaries}

Begin the assessment process by unambiguously stating the objective of conducting the assessment. Most commonly, this will be to determine how a proposed project will impact wetland functions; however, there are other potential objectives:

- Compare several wetlands as part of an alternatives analysis.

- Identify specific actions that can be taken to minimize project impacts.

- Document baseline conditions at a wetland site.

- Determine mitigation requirements.

- Determine mitigation success.

- Evaluate the likely effects of a wetland management technique.

Next, locate on a map one or more separate Wetland Assessment Areas (WAAs) based on the Key to Wetland Classes (Figure 9), the wetland subclass descriptions (Table 5) and the project area boundary. Attach this map and all supporting maps, photos, and drawings to Data Form A1 and complete the first three columns of the table on Data Form A1 by assigning an identifying number to each WAA, specifying the subclass it belongs to, and calculating the area (hectares). 
Table 6. Red Flag Features and Respective Program/Agency Authority.

\begin{tabular}{|c|c|}
\hline Red Flag Features & Authority 1 \\
\hline Native Lands and areas protected under American Indian Religious Freedom Act & A \\
\hline $\begin{array}{l}\text { Hazardous waste sites identified under Comprehensive Environmental Response, } \\
\text { Compensation, and Liability Act (CERCLA or Superfund) or Resource Conservation and } \\
\text { Recovery Act (RCRA) }\end{array}$ & $\mathrm{E}, \mathrm{G}$ \\
\hline Areas providing Critical Habitat for Species of Special Concern & $B, C$ \\
\hline Areas covered under the Farmland Protection Act & I \\
\hline Floodplains, floodways, or floodprone areas & $E, L, M$ \\
\hline Areas with structures/artifacts of historic or archeological significance & $\mathrm{L}$ \\
\hline Areas protected under the Land and Water Conservation Fund Act & I \\
\hline National Wildlife Refuges and special management areas & $B, C$ \\
\hline Areas identified in the North American Waterfowl Management Plan & $B, C$ \\
\hline Areas identified as significant under the Ramsar Treaty & $B, E$ \\
\hline Areas supporting rare or unique plant communities & $B, C$ \\
\hline Areas designated as Sole Source Groundwater Aquifers & $E, G, J, K, M$ \\
\hline Areas protected by the Safe Drinking Water Act & $\mathrm{E}, \mathrm{G}, \mathrm{J}, \mathrm{M}$ \\
\hline City, County, State, and National Parks & $B, D, J, L$ \\
\hline Areas supporting threatened or endangered species & $B, C, G$ \\
\hline Areas with unique geological features & B \\
\hline Areas protected by the Wild and Scenic Rivers Act or Wilderness Act & D \\
\hline \multicolumn{2}{|l|}{1 Program Authority / Agency } \\
\hline \multicolumn{2}{|l|}{$A=$ Bureau of Indian Affairs } \\
\hline \multicolumn{2}{|l|}{$\mathrm{B}=$ Texas Parks and Wildlife Department } \\
\hline \multicolumn{2}{|l|}{ C $=$ U.S. Fish and Wildlife Service } \\
\hline \multicolumn{2}{|l|}{ D = National Park Service (NPS) } \\
\hline \multicolumn{2}{|l|}{$\mathrm{E}=$ Texas Commission on Environmental Quality } \\
\hline \multicolumn{2}{|l|}{ G = State Historic Preservation Officer (SHPO) } \\
\hline \multicolumn{2}{|l|}{ I = U.S. Environmental Protection Agency } \\
\hline \multicolumn{2}{|l|}{$\mathrm{J}=$ Federal Emergency Management Administration } \\
\hline \multicolumn{2}{|l|}{$K=$ Natural Resource Conservation Service } \\
\hline \multicolumn{2}{|l|}{$\mathrm{L}=$ Local Government Agencies } \\
\hline $\mathrm{M}=$ Texas Water Development Board & \\
\hline
\end{tabular}

\section{Each WAA is a portion of the project area that belongs to a single regional} wetland subclass and is relatively homogeneous with respect to the criteria used to assess wetland functions (i.e., hydrologic regime, vegetation structure, topography, soils, successional stage). However, as the size and 
heterogeneity of the project area increase, it is more likely that it will be necessary to define and assess multiple WAAs within a project area.

There are at least three identifiable situations that would necessitate the designation of multiple WAAs within a single project area. The first situation occurs when separate areas of wetlands belonging to the same regional subclass occur in the project area. Such noncontiguous wetlands must be designated as separate WAAs because the assessment process includes consideration of the size and isolation of individual wetland units. The second situation occurs where more than one regional wetland subclass occurs within a project area. These must be separated because they are assessed using different models and reference data systems. The third situation occurs where a contiguous wetland area of the same regional subclass exhibits spatial heterogeneity in terms of hydrology, vegetation, soils, or other assessment criteria.

In alluvial valleys of East Texas, the most common reasons to designate multiple WAAs involve tracts of land with interspersed regional subclasses (such as depressions scattered within a matrix of riverine wetlands) or tracts composed of a single regional subclass that includes areas with distinctly different land use influences that produce different land cover. For example, within a large riverine backwater unit, separate WAAs that are cleared land, early successional sites, and mature forests may be defined. The establishment of multiple WAAs also may be dictated by projected future conditions including different management approaches or restoration plans. However, one should be cautious about splitting a project area into many WAAs based on relatively minor differences, such as local variation due to canopy gaps and edge effects. The reference curves used in this document (Chapter 5) incorporate such variation, and splitting areas into numerous WAAs based on subtle differences will not materially change the outcome of the assessment. It will, however, greatly increase the sampling and analysis requirements. Field experience in the region should provide a sense of the range of variability that typically occurs, and is sufficient to make reasonable decisions in defining multiple WAAs.

\section{Collect Field Data}

Information on the variables used to assess the functions of regional wetland subclasses in alluvial valleys of East Texas is collected at several different spatial scales, and requires several summarization steps. The checklists and data forms in the appendices are designed to assist the 
assessment team in assembling the required materials and proceeding in an organized fashion. As noted previously, the Project Information and Assessment Documentation form (Appendix A1) is intended to be used as a cover sheet and for an overview of all documents and data forms used in the assessment. Assembling the background information listed on this form should guide the assessment team in determining the number, types, and sizes of the separate WAAs likely to be designated within the project area (see above). Based on that information, the field gear and data form checklists in Appendix A2 should be used to assemble the needed materials before heading to the field to conduct the assessment.

Note that different wetland subclasses require different field data forms, because the assessment variables differ among subclasses (Table 7). Use the Data Sheets checklist in Appendix A2 to determine how many of each form are needed, then make copies of the required forms, which are provided in Appendix B. Data sheets may also be printed directly from the FCI/ FCU calculator spreadsheet (see Appendix C2).

The data forms provided in Appendix B are organized to facilitate data collection at each of the several spatial scales of interest. For example, the first group of variables on Data Sheet 1 contains information about landscape scale characteristics collected using aerial photographs, maps, and hydrologic information regarding each WAA and vicinity. Information on the second group of variables on Data Sheet 1 is collected during a walking reconnaissance of the WAA. Data collected for these two groups of variables are entered directly on the data forms, and do not require plotbased sampling. Information on the next group of variables is collected in sample plots placed in representative locations throughout the WAA. Data from a single plot are recorded on Data Sheet 2. Additional copies of Data Sheet 2 are completed for each plot sampled within the WAA. All summary data from each of the data forms are compiled on Data Sheet 3 prior to entry into the spreadsheet that calculates the functional capacity of the wetland being assessed.

The sampling procedures for conducting an assessment require few tools, but certain tapes, a shovel, specialized basal area estimation or measurement tools, reference materials, and an assortment of other items listed in Appendix A2 will be needed. Generally, all measurements should be taken in metric units (although non-SI equivalents are indicated for most sampling criteria such as plot sizes). 
Table 7. Applicability of assessment variables by Regional Wetland Subclass.

\begin{tabular}{|c|c|c|c|}
\hline Variable Code & Low-Gradient Riverine & Mid-Gradient Riverine & Connected Depression \\
\hline$V_{A H O R}$ & + & + & * \\
\hline$V_{\text {BUF30 }}$ & not used & + & + \\
\hline$V_{B U F 250}$ & not used & + & + \\
\hline$V_{\text {COMP }}$ & + & + & + \\
\hline$V_{D U R}$ & + & + & + \\
\hline$V_{F R E Q}$ & + & + & + \\
\hline$V_{G V C}$ & + & + & * \\
\hline$V_{\text {LITTER }}$ & + & + & * \\
\hline$V_{\text {LOG }}$ & + & + & * \\
\hline$V_{O H O R}$ & + & + & * \\
\hline$V_{\text {PATCH }}$ & + & not used & not used \\
\hline VPOND & + & + & not used \\
\hline$V_{S N A G}$ & + & + & + \\
\hline Vsoll & + & + & * \\
\hline VSSD & + & + & + \\
\hline$V_{\text {StRATA }}$ & + & + & + \\
\hline$V_{T B A}$ & + & + & + \\
\hline$V_{\text {TCOMP }}$ & + & + & + \\
\hline$V_{T D E N}$ & + & + & + \\
\hline$V_{W D}$ & + & + & * \\
\hline
\end{tabular}

A typical layout for the establishment of sample plots and transects is shown in Figure 13. As in defining the WAA, there are elements of subjectivity and practicality in determining the number of sample locations for collecting plot-based and transect-based site-specific data. The exact numbers and locations of the plots and transects are dictated by the size and heterogeneity of the WAA. If the WAA is relatively small (i.e., less than 2- 3 acres, or about a hectare) and homogeneous with respect to the characteristics and processes that influence wetland function, then three or four 0.04-ha plots, with associated nested transects and subplots in representative locations, are probably adequate to characterize the WAA. Experience has shown that the time required to complete an assessment of an area that size is $2-4 \mathrm{hr}$, depending primarily on the 


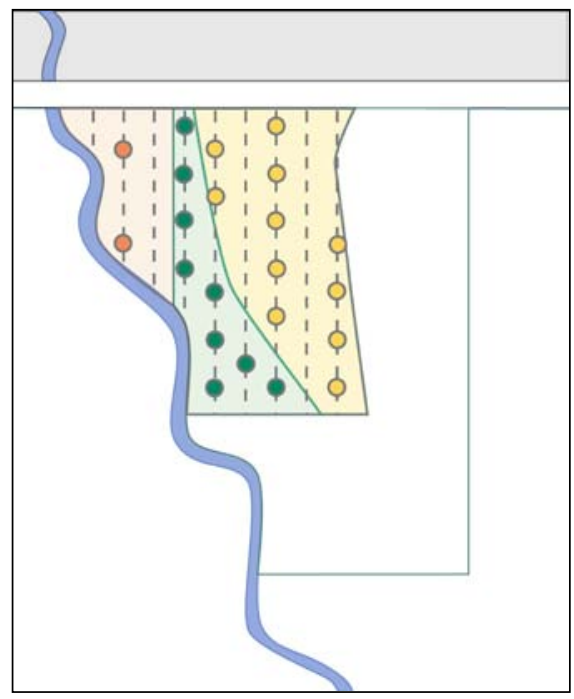

Figure 13. Example sample distribution in three wetland assessment areas. experience of the assessment team. However, as the size and complexity of the WAA increase, more sample plots are required to represent the site accurately. Large forested wetland tracts usually include a mix of tree age classes, scattered small openings in the canopy that cause locally dense understory or ground cover conditions, and perhaps some very large individual trees or groups of old-growth trees. The sampling approach should not bias data collection to emphasize or exclude any of these local conditions differentially, but to represent the site as a whole. Therefore, the best approach often is a simple systematic plot layout, where evenly spaced parallel transects are established (using a compass and pacing) and sample plots are distributed at regular paced intervals along those transects. For example, a 12-ha tract, measuring about $345 \mathrm{~m}$ on each side, might be sampled using two transects spaced $100 \mathrm{~m}$ apart (and $50 \mathrm{~m}$ from the tract edge), with plots at 75-m intervals along each transect (starting $25 \mathrm{~m}$ from the tract edge). This would result in eight sampled plot locations, which should be adequate for a relatively diverse 12-ha forested wetland area. Larger or more uniform sites can usually be sampled at a lower plot density. One approach is to establish a series of transects, as described previously, and sample at intervals along alternate transects. Continue until the entire site has been sampled at a low plot density, then review the data and determine if the variability in overstory composition and basal area has been largely accounted for. That is, as the number of plots sampled has increased, are new dominant species no longer being encountered, and has the average basal area for the site changed markedly with the addition of recent samples? If not, there is probably no need to add further samples to the set. If overstory structure and composition variability remain high, then return to the alternate, unsampled transects and continue sampling until the data set is representative of the site as a whole, as indicated by a leveling off of the dominant species list and basal area values. Other variables may level off more quickly or slowly than tree composition and basal area; but these two factors are generally good indicators, and correspond well to the overall suite of characteristics of interest within a particular WAA. In some cases, such as sites where trees have been planted or composition and structure are highly uniform (e.g., 
sites dominated by a single tree species), it may be apparent that relatively few samples are adequate to reasonably characterize the wetland.

The information on Data Sheets 1 and 2 (Appendix B) are entered in the spreadsheet and automatically tabulated (Appendix C1). The overall assessment summary is presented on the FCI/ FCU summary page of the spreadsheet (Appendix C2). All of the field and summary data forms, as well as the printed output from the final spreadsheet calculations, should be attached to the Project Information and Assessment Documentation Form provided in Appendix A. Appendix D is a listing of common and scientific names of tree and shrub species that are referenced on the field data forms.

Detailed instructions on collecting the data for entry on Data Sheets 1 and 2 follow. Where plot and point samples are required, refer to the plot layout diagram in Figure 14. Variables are listed in alphabetical order by variable codes to facilitate locating them. Not all variables are used to assess all subclasses, as described in Chapter 5 and Table 6, but the data forms in Appendix B indicate which variables are pertinent to each subclass. The data forms also provide brief summaries of the methods used to assess each variable, but the user should read through these more detailed descriptions and have them available in the field for reference as necessary.

\section{$V_{A H O R}$ - A Horizon Organic Accumulation}

This variable represents total mass of organic matter in the A soil horizon, a mineral soil horizon that occurs at the ground surface, below the $\mathrm{O}$ soil horizon, consisting of an accumulation of unrecognizable decomposed organic matter mixed with mineral soil (U.S. Department of Agriculture (USDA) Soil Conservation Service 1993). In practice, the HGM models using this variable are concerned with the storage of organic matter, so for these purposes the A horizon is identified in the field simply as a zone of darkened soil.

Thickness of the A horizon is the metric used to quantify this variable. Measure it using the following procedure:

Establish sample points by selecting two or more locations within the 0.04-ha circular plot that are representative of the range of microtopographic conditions in the plot, or select two or more of the four 1- $\mathrm{m}^{2}$ subplots established for litter and ground cover estimation. Dig a hole 
( $25 \mathrm{~cm}$ or $10 \mathrm{in}$. deep is usually adequate) and measure the thickness of the A horizon. Record subplot measurements in centimeters on Data Form 2.

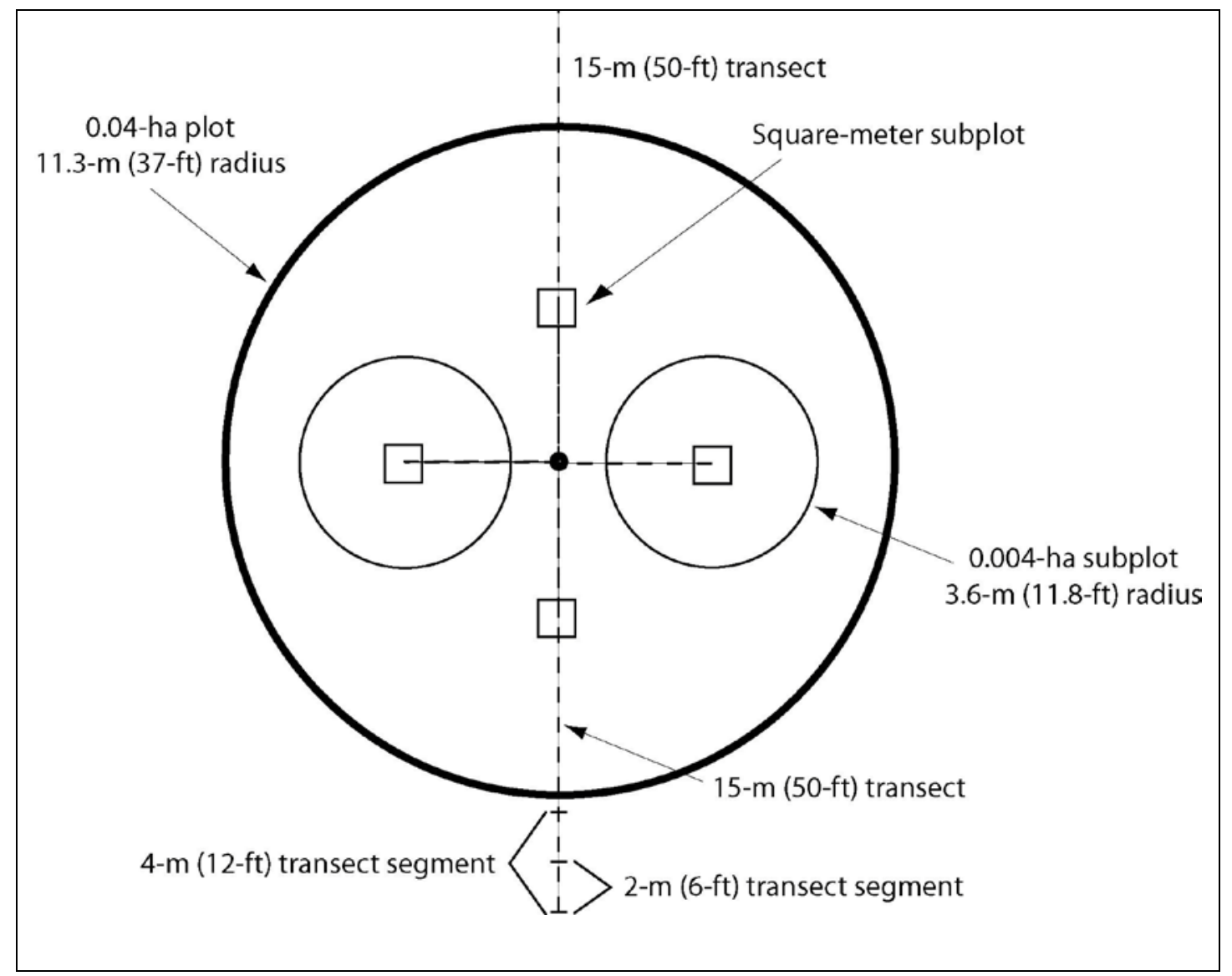

Figure 14. Layout of plots and transects for field sampling.

\section{$V_{B U F 30}$ - Percent of Perimeter Bounded by 30-m Buffer}

This variable describes the percentage of the wetland perimeter bounded by a 30-m buffer that provides contiguous habitat with appropriate characteristics to meet the "general use" habitat needs (basking, feeding, limited nesting, and hibernation) of many reptiles and amphibians. Note that the buffer can consist of any community type that is usually "drier" than the depression or riverine wetland - this can include flats and other wetlands as well as uplands. Acceptable buffer community types include native forest, prairie, and shrub/ scrub habitats, but not areas dominated by non-native species such as pasture grasses or densely vegetated oldfield habitats. Managed pine forest is acceptable if soils, litter, and groundlayer vegetation have not been extensively disturbed (e.g., bedded) such that there is no cover or animal movement is impeded. 
In the following discussion, the potential buffer area is assumed to completely surround wetlands in depressions. However, for wetlands along mid-gradient streams the variable is approached differently. The width and depth of mid-gradient streams are likely to represent a barrier to movement or exposure to predators for many of the species of greatest interest with regard to this variable. Therefore, for mid-gradient riverine wetlands, buffer widths are calculated for only that side of the stream where the wetland is present.

Determine the value of this metric using the following procedure, and refer to Figure 15 as needed.

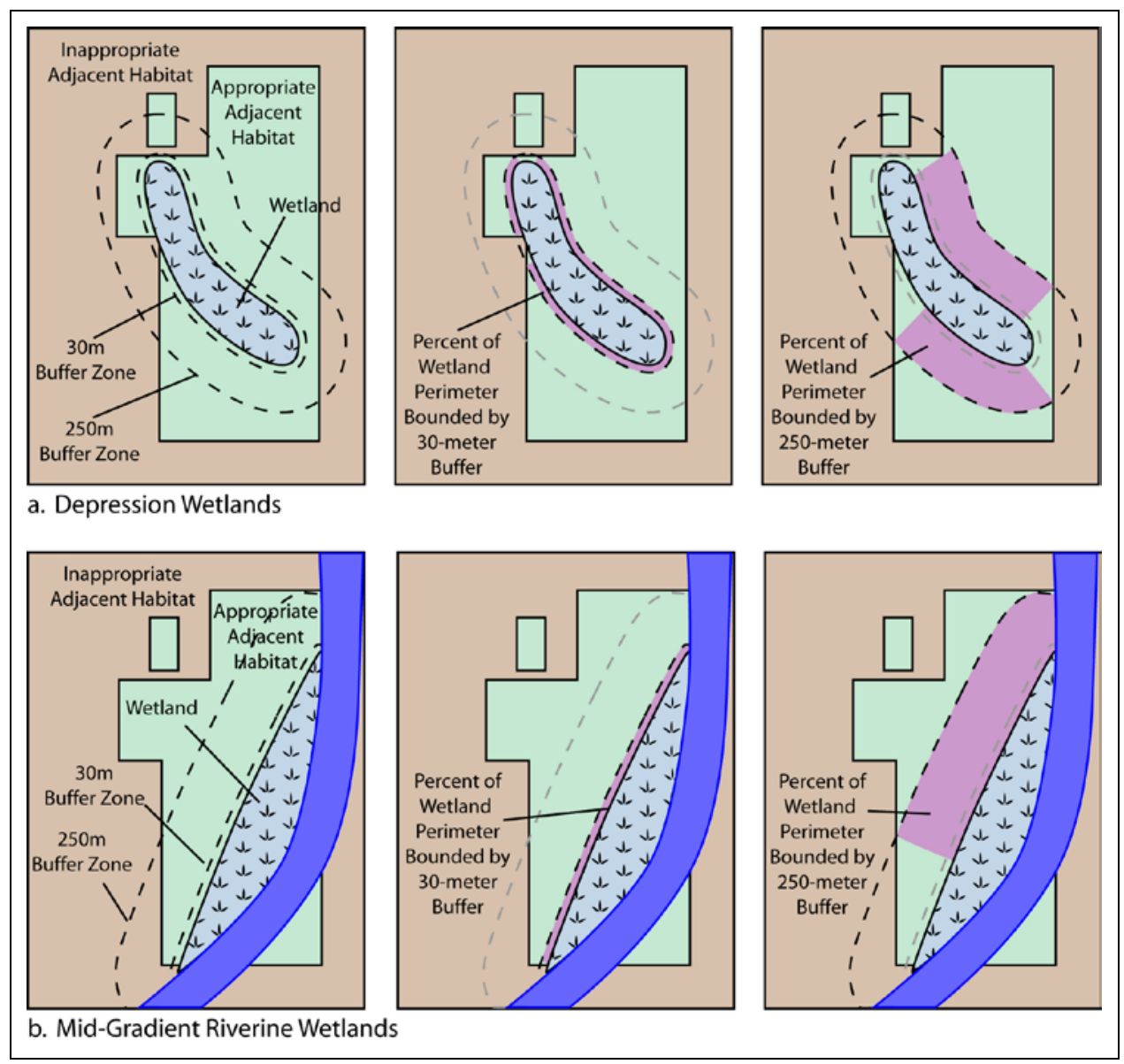

Figure 15. Measurement of buffer characteristics.

1. For depression wetlands, draw a continuous line on a map or photo separating the WAA from adjacent uplands or other wetland subclasses. This line defines the inner edge of the 30 -m buffer zone.

2. Draw a second line $30 \mathrm{~m}$ outside the wetland boundary line. This defines the outer limit of the 30-m buffer zone. 
3. Identify and mark the boundaries of the appropriate habitats within the buffer zone. If the boundary of appropriate habitat intersects the boundary of the 30-m buffer, draw a line perpendicular to the wetland boundary to determine where along the perimeter the full $30-\mathrm{m}$ buffer ends. Areas of appropriate habitat that are not contiguous with the wetland boundary will not be considered in this metric.

4. Visually estimate the perœentage of the wetland perimeter bounded by a full 30-m buffer. This is actually measured as a lineal pencentage. Consider the wetland outline to be a clock face. In Figure 15a, the full 30-m buffer runs from roughly 12:15 to 9:30, and then again from 10:00 to 11:45 or $11 / 12=92$ percent. Record that percentage on Data Sheet 1 .

5. For mid-gradient riverine wetlands, use the same approach, but restrict the procedure to the same side of the stream where the wetland oocurs. In the example shown in Figure 15b, the continuity of the 30-m buffer is 100 percent.

\section{$V_{\text {BUf250 - Percent of Perimeter Bounded by 250-m Buffer }}$}

This variable describes the percentage of the wetland perimeter bounded by a 250 -m buffer that provides contiguous habitat with appropriate characteristics to meet nesting, hibernation, and other habitat needs of a broad suite of reptiles and amphibians. Note that the buffer can consist of any community type that is usually drier than the depression wetland this can include flats and riverine wetlands as well as uplands. Acceptable buffer community types include native forest, prairie, and shrub/ scrub habitats, but not dense emergent communities or areas dominated by nonnative species such as pasture grasses. Managed pine forest is acceptable if soils, litter, and ground-layer vegetation have not been extensively disturbed (e.g., bedded) such that there is no cover or animal movement is impeded.

In the following discussion, the potential buffer area is assumed to completely surround wetlands in depressions. However, for wetlands along mid-gradient streams the variable is approached differently. The width and depth of mid-gradient streams are likely to represent a barrier to movement or exposure to predators for many of the species of greatest interest with regard to this variable. Therefore, for mid-gradient riverine wetlands, buffer widths are calculated for only that side of the stream where the wetland is present. 
Determine the value of this metric using the following procedure, and refer to Figure 15 as needed.

1. On a map or photo, draw a continuous line separating the depression WAA from adjacent uplands or other wetland subclasses. This line defines the inner edge of the 250-m buffer zone.

2. Draw a second line $250 \mathrm{~m}$ outside the wetland boundary line. This defines the outer limit of the 250 -m buffer zone.

3. Identify and mark the boundaries of the appropriate habitats within the buffer zone. If the boundary of appropriate habitat intersects the boundary of the 250-m buffer, draw a line perpendicular to the wetland boundary to determine where along the perimeter the full 250 -m buffer ends. Areas of appropriate habitat that are not contiguous with the wetland boundary will not be considered in this metric.

4. Visually estimate the perœentage of the wetland perimeter bounded by a full 250-m buffer. This is actually measured as a lineal percentage. Consider the wetland outline to be a clock face. In Figure 15a, the full 250$m$ buffer runs from roughly 1:15 to 5:00 and then again from 6:00 to 8:30, or $6.25 / 12=52$ percent. Record that percentage on Data Sheet 1 .

5. For mid-gradient riverine wetlands, use the same approach, but restrict the procedure to the same side of the stream where the wetland oocurs. In the example shown in Figure 15b, the continuity of the 250-m buffer is approximately 70 percent.

\section{V comp - Composition of Tallest Woody Vegetation Stratum}

This variable represents the species composition of the tallest woody stratum present in the assessment area. This could be the tree, shrubsapling, or seedling stratum. Percent concurrence with reference wetlands of the dominant species in the dominant vegetation stratum is used to quantify this variable. Measure it using the following procedure:

1. Determine percent cover of the tree stratum by visually estimating what percentage of the sky is blocked by leaves and stems of the tree stratum, or vertically projecting the leaves and stems to the forest floor. If desired, a more quantitative measure of cover can be obtained with a densiometer (httpp//www.tceq.state.tx.us/assets/public/comm_exec/pubs/rg/swqmp2/chapter_9.pdf. If the percent cover of the tree stratum is estimated to be at least 20 percent, go to Step 2. If the percent cover of the tree stratum is estimated to be $<20$ percent, skip Step 2 and go directly to Step 3. 
2. If the tree stratum has at least 20 percent cover, then the value for $\mathrm{V}_{\mathrm{COMP}}$ will be the same as the value for $\mathrm{V}_{\mathrm{TCOMP}}$. In this case, skip the remaining steps and simply enter the $\mathrm{V}_{\text {TCOMP }}$ value (see $\mathrm{V}_{\text {TCOMP }}$ discussion) on Data Sheet 2.

3. If the tree stratum does not have at least 20 percent cover, determine the tallest woody stratum with at least 10 percent total cover. Within this stratum, identify the dominant species based on percent cover using the following procedure: rank species in descending order of percent cover and identify dominants by summing relative dominance in descending order until 50 percent is exceeded; additional species with 20 percent relative dominance should also be included as dominants. Check these species on Data Sheet 2 of the appropriate wetland subclass. Accurate identification of woody species is critical for determining the dominant species in each plot. Sampling during the dormant season may require proficiency in recognizing plant form, bark, and dead or dormant plant parts. Users who do not feel confident in identifying trees and shrubs should seek assistance.

\section{$V_{D U R}$ - Change in Growing Season Flood Duration}

Growing season flood duration refers to the maximum number of continuous days in the growing season that overbank or backwater flooding from a stream inundates the WAA. Riverine and Connected Depression wetlands may flood as infrequently as one year in five (see the discussion of the $V_{\text {FREQ }}$ variable in the following section). However, when flooding does occur, it usually extends for some days or weeks into the growing season, and strongly influences plant and animal communities. In some cases, where impoundments are constructed around existing wetlands (e.g., greentree reservoirs) or where stream engineering activities such as flood control projects are constructed, additional growing season flooding may occur in the spring or fall. The $\mathrm{V}_{\text {DUR }}$ variable is intended to reflect changes in function that result where changes in growing season hydrology have occurred or are expected to occur as a result of leveeing, drainage, impoundment, or other engineering projects. Either increases or decreases in growing season flood durations are assumed to cause reduced function relative to the pre-impact condition for both the Maintain Plant Communities and Provide Wildlife Habitat functions.

In order to account for this type of change, the $\mathrm{V}_{\text {DUR }}$ variable is incorporated in the relevant models. The $\mathrm{V}_{\text {DUR }}$ variable was developed based on field studies on greentree reservoirs in the Bayou Meto Basin of Arkansas 
(Heitmeyer and Ederington 2004), where changes in flood duration were expressed in terms of continuous days of flooding in the growing season. Changes in flood duration are presented as "zone changes," where a single zone change corresponds to approximately one week of additional or reduced continuous flooding during the growing season. Because these data are usually generated to evaluate likely project-induced changes in the acreage of jurisdictional wetlands, the "period of continuous flooding" may not correspond to the total days of flooding. At this time, no specific correlation has been established between this means of presenting flood duration data and the more common method of discussing flood durations that are based on total days of flooding in the entire annual cycle.

Estimates of growing-season flood durations are not typically readily available for any particular site, and in most cases the change in duration will be assumed to be zero unless specific information to the contrary is available from project planning or permit application documents. Whatever the case, the percent change should be calculated consistently for the before-project and after-project conditions as follows:

1. Determine the change in growing season flood duration by comparing the preproject and postproject flood durations.

2. Record the preproject and postproject growing season flood durations on Data Sheet 1. Changes greater than five zone changes should be recorded as “5."

\section{$V_{F R E Q}-$ Change in Frequency of Flooding}

Frequency of flooding refers to the frequency (return interval in years) with which overbank or backwater flooding from a stream inundates the WAA. In the classification employed here, where the 5-year return interval distinguishes connected wetlands from unconnected wetlands, the frequencies of interest are the 1-, 2-, 3-, 4-, and 5-year return intervals. However, in the context of the assessment models where the $V_{\mathrm{FREQ}}$ variable is used, there is no implication that more frequent flooding translates to higher functionality. Rather, all connected wetlands are assumed to be fully functional with regard to the $V_{F R E Q}$ variable unless there has been a change in flood frequency, and any such change, whether more or less frequent, will have adverse effects on the wetland communities and processes currently in place. (Note: As with the classification system, flood frequencies established as a result of the major river engineering projects in the mid-twentieth century are considered to be the baseline condition in most assessment 
scenarios.) In practice, the change in flood frequency will be a consideration most often where the hydrology of a site has been recently modified, as through a levee, drainage, or pumping project, or where such a change is proposed. In such situations the change in flood frequency can be used to indicate the magnitude of deviation from the preproject condition, calculated as follows:

1. Determine the change in recurrence interval by comparing the preproject and postproject flood frequencies. For the preproject condition, the recurrence interval can be determined or estimated using one of the following information sources:

- Recurrence interval map

- Data from a nearby stream gage

- Regional flood frequency curves developed by local and State offices of USACE, U.S. Geological Survey (USGS) - Water Resources Division, State Geologic Surveys, or NRCS (J ennings et al. 1994)

- Hydrologic models such as HEC-2 (Hydrologic Engineering Center 1981, 1982), HEC-RAS (Hydrologic Engineering Center 1997), or Hydrologic Simulation Program - Fortran (HSPF) (Bicknell et al. 1993)

- Local knowledge

- A regional dimensionless rating curve

The same sources may be used to determine the postproject recurrence interval, or it may be specified in planning documents and applications.

2. Record the preproject and postproject recurrence intervals on Data Sheet 1 . Note that the final number can be a fraction (e.g., 1.5 years) if the available information supports such a specific estimate, and that only the change is of concern, not whether it is positive or negative.

Example: A riverine site that normally floods every year (5 years out of 5) will be affected by a nearby channel-deepening project that reduoes flood frequency to 2 years out of 5 . The change in return interval is 3 years.

Note that the number of possible changes in return interval varies depending on the starting flood frequency. This is due in part to the 
classification of the flood frequencies: any area flooded more frequently than once a year is grouped with the 1-year return interval group, and everything flooded less frequently than every 5 years is no longer classified as riverine, and therefore the frequency variable no longer applies. As Figure 16 illustrates, the maximum of four zone changes is possible only for wetlands starting in the 1- or 5-year return interval categories (blue and red). This maximum change leads to a 0.2 variable subindex. In contrast, if the starting return interval is 3 years, a maximum of two zone changes is possible in either direction (green line), leading to a potential subindex of 0.6 . A subindex of 0.0 occurs only if the change in frequency extends beyond the 5-year return interval required in the definition of riverine wetlands.

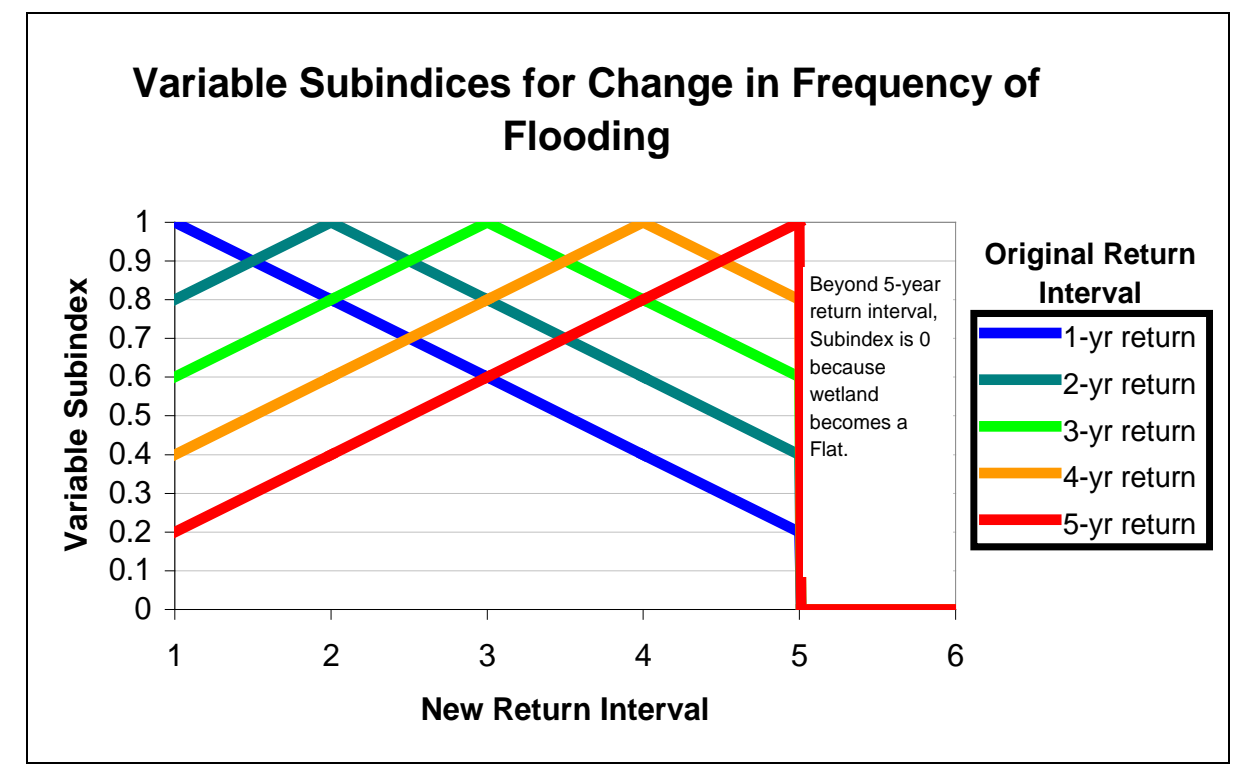

Figure 16. Potential variable subindices for different starting return interval frequencies.

\section{$V_{G V C}$ - Ground Vegetation Cover}

Ground vegetation cover is defined as herbaceous and woody vegetation less than or equal to $1.4 \mathrm{~m} \mathrm{(} 4.5 \mathrm{ft}$ ) in height. The percent cover of ground vegetation is used to quantify this variable. Determine the value of this metric using the following procedure:

Visually estimate the proportion of the ground surface that is covered by ground vegetation by mentally projecting the leaves and stems of ground vegetation to the ground surface. Do this in each of four $1-\mathrm{m}^{2}$ subplots placed $5 \mathrm{~m}$ ( $15 \mathrm{ft}$ ) from the plot center, one in each cardinal direction as 
illustrated in Figure 14. Record measurements for each subplot on Data Sheet 2.

\section{LITTER - Litter Cover}

Litter cover is estimated as the average percent of the ground surface covered by recognizable dead plant materials (primarily decomposing leaves and twigs). This estimate excludes undecomposed woody material large enough to be tallied in the woody debris transects (i.e., twigs larger than $0.6 \mathrm{~cm}$ ( $0.25 \mathrm{in}$.) in diameter - see $\mathrm{V}_{\mathrm{WD}}$ discussion). It also excludes organic material sufficiently decayed to be included in the estimate of $\mathrm{O}$ horizon thickness (see $\mathrm{V}_{\mathrm{OHOR}}$ discussion). Generally, litter cover is easily recognized and estimated except during autumn, during active leaf fall, when freshly fallen materials should be disregarded in making the estimate, because the volume of freshly fallen material will inflate cover estimates.

The percent cover of litter is used to quantify this variable. Determine the value of this metric using the following procedure:

Visually estimate the proportion of the ground surface covered by litter in each of the four 1- $\mathrm{m}^{2}$ subplots (the same subplots established for estimating ground vegetation cover, Figure 14). Record measurements for each subplot on Data Sheet 2.

\section{$V_{\text {LOG }}$ - Log Biomass}

See discussion in the Woody Debris $\left(\mathrm{V}_{\mathrm{WD}}\right)$ section later in this chapter.

\section{VOHOR - 0 Horizon Organic Accumulation}

The O horizon is defined as the soil layer dominated by organic material that consists of partially decomposed organic matter such as leaves, needles, sticks, or twigs $<0.6 \mathrm{~cm}$ in diameter, flowers, fruits, insect frass, dead moss, or detached lichens on or near the surface of the ground. The $O$ horizon does not include recently fallen material or material that has been incorporated into the mineral soil.

Thickness of the $\mathrm{O}$ soil horizon is the metric used to quantify this variable. Measure it using the following procedure: 
Measure the thickness of the $\mathrm{O}$ horizon in the same holes dug to determine the thickness of the A horizon (discussed previously). That will result in two or more measurements per plot, which are recorded as subplot values in the $\mathrm{V}_{\mathrm{OHOR}}$ section of Data Sheet 2.

\section{$V_{\text {PATCH }}$ - Forest Patch Size}

This variable is defined as the area of contiguous forest that includes the WAA. This may include nonwetland forests adjacent to the WAA, but all areas considered forest should have more than 70 percent canopy tree cover.

Determine the size of the forested patch using the following procedure:

1. Determine the size of the forested area (ha) that is contiguous and directly accessible to wildlife utilizing the WAA (including the WAA itself, if it is forested). Use topographic maps, aerial photography, a geographic information system, field reconnaissance, or another appropriate method.

2. Record the area in hectares (if the area exceeds 2500 ha, simply reoord 2500) on Data Sheet 1.

\section{$V_{P O N D}$ - Total Ponded Area}

Total Ponded Area refers to the percent of the WAA ground surface likely to collect and hold precipitation for periods of days or weeks at a time. (Note: This is distinct from the area that is prone to flooding, where the surface of the WAA is inundated by overbank or backwater connections to stream channels.) The smaller (microtopographic) depressions are usually a result of tree "tip ups" and the scouring effects of moving water, and typically they are between 1 and $10 \mathrm{~m}^{2}$ in area. Larger vernal pools (usually at least 0.04 ha) occur in the broad swales typical of meander scroll topography or in other areas where impeded drainage produces broad, shallow pools during rainy periods. The wetlands where these features are important typically have a mix of both the small microdepressions and the larger vernal pools.

Estimate total ponded area using the following procedure:

During a reconnaissance walkover of the entire WAA, estimate the percentage of the assessment area surface having microtopographic depressions and vernal pool sites capable of ponding rainwater. Base 
the estimate on the actual presence of water immediately following an extended rainy period if possible, but during dry periods use indicators such as stained leaves or changes in ground vegetation cover.

Generally, it is not difficult to visualize the approximate percentage of the area subject to ponding, but it is important to base the estimate on a walkover of the entire assessment area.

Report the percent of the assessment area subject to ponding on Data Sheet 1.

\section{$V_{\text {SNAG - Snag Density }}$}

Snags are standing dead woody stems at least $1.4 \mathrm{~m}(4.5 \mathrm{ft})$ tall with a dbh greater than or equal to $10 \mathrm{~cm}$ ( 4 in). The density of snag stems per hectare is the metric used to quantify this variable. Measure it using the following procedure:

Count the number of snag stems within each 0.04-ha circular plot. Record the number of snag stems in the indicated box on the $\mathrm{V}_{\mathrm{SNAG}}$ row on Data Sheet 2 .

\section{$V_{\text {soll }}$ - Soil Integrity}

It is difficult in a rapid assessment context to evaluate soil integrity for two reasons. First, a variety of soil properties contributing to integrity should be considered (i.e., structure, horizon development, texture, bulk density). Second, the spatial variability of soils within many wetlands makes it difficult to collect the number of samples necessary to adequately characterize a site. Therefore, the approach used here is to assume that soil integrity exists where evidence of alteration is lacking. Stated another way, if the soils in the assessment area do not exhibit any of the characteristics associated with alteration, it is assumed that the soils are similar to those occurring in the reference standard wetlands and have the potential to support a characteristic plant community.

This variable is measured as the proportion of the assessment area with altered soils. Measure it using the following procedure:

1. As part of the reconnaissance walkover of the entire WAA, determine if any of the soils in the area being assessed have been altered. In particular, note roads, berms, ditches, parking areas and similar features, as well as 
other evidence of excavation, fill, or severe compaction. For the purposes of this assessment approach, the presence of a plow layer should not be considered a soil alteration.

2. If no altered soils exist, the percent of the assessment area with altered soils is zero. This indicates that all of the soils in the assessment area are similar to soils in reference standard sites.

3. If altered soils exist, estimate the percentage of the assessment area that has soils that have been altered.

4. Report the percent of the assessment area with altered soils on Data Sheet 1.

\section{VSSD - Shrub-Sapling Density}

Shrubs and saplings are woody stems less than $10 \mathrm{~cm}$ (4 in.) dbh and greater than $1.4 \mathrm{~m}$ ( $4.5 \mathrm{ft}$ ) in height. Density of shrub-sapling stems per hectare is the metric used to quantify this variable. Measure it using the following procedure:

Count woody stems less than $10 \mathrm{~cm}$ ( 4 in.) and greater than $1.4 \mathrm{~m}$ ( $4.5 \mathrm{ft}$ ) in height in two 0.004 -ha circular subplots (radius $3.6 \mathrm{~m}$ or $11.8 \mathrm{ft}$ ) nested within the 0.04-ha plot (Figure 14). Record the number of stems in each 0.004-ha subplot in the spaces provided in the VSSD row on Data Sheet 2.

\section{VStRATA - Number of Vegetation Strata}

The number of vegetation layers (strata) present in a forested wetland reflects the diversity of food, cover, and nest sites available to wildlife, particularly birds, but also to many reptiles, invertebrates, and arboreal mammals. Estimate the vertical complexity of the WAA using the following procedure:

1. During a reconnaissance walkover of the entire WAA, identify which of the following vegetation layers are present and account for at least 10 percent cover, on average, throughout the site:

- Canopy (trees greater than or equal to $10 \mathrm{~cm}$ dbh in the canopy layer)

- Subcanopy (trees greater than or equal to $10 \mathrm{~cm}$ dbh below the canopy layer - recognize this layer if it is distinctly different from a higher, more mature canopy) 
- Understory (shrubs and saplings less than $10 \mathrm{~cm}$ dbh but at least $1.4 \mathrm{~m}(4.5 \mathrm{ft}$ tall $))$

- Ground cover (woody plants less than $1.4 \mathrm{~m}$ (4.5ft) tall and herbaceous vegetation)

2. Enter the number of vegetation strata $(0-4)$ present in the $V_{\text {STRATA }}$ row on Data Sheet 1.

\section{$V_{T B A}$ - Tree Basal Area}

Trees are defined as living woody stems greater than or equal to $10 \mathrm{~cm}$ (4 in.) dbh, which typically includes plants that are in the canopy, or overstory, layer in a mature forest. Tree basal area is a common measure of abundance and dominance in forest ecology that has been shown to be proportional to tree biomass (Spurr and Barnes 1981, Whittaker 1975). Tree basal area per hectare is the metric used to quantify this variable. Measure it using the following procedure:

Use a basal area wedge prism (or other basal area estimation tool) as directed to tally eligible tree stems, and enter the tally in the indicated space on the $V_{\text {TBA }}$ line on Data Sheet 3. Basal area prisms are available in various Basal Area Factors, and in both SI and non-SI versions. Some are inappropriate for use in collecting the data needed here, because they are intended to be used for large-diameter trees in areas with little understory. The non-SI 10-factor prism works well for these purposes, and it is readily available.

\section{$V_{\text {TCoMP }}$ - Tree Composition}

The tree composition variable is intended to represent the pattern of dominance among tree species in the forest canopy. $V_{\text {TCOMP }}$ is calculated if the total canopy cover of trees (living woody stems $\geq 10 \mathrm{~cm}$ or $4 \mathrm{in}$. at breast height) within the plot is 20 percent or more. Percent concurrence of the dominant tree species in the assessment area with the species composition of reference wetlands in various conditions is the metric used to quantify this variable. Measure it with the following procedure:

If the tree stratum has at least 20 percent cover, identify the dominant species (based on cover or on basal area if dbh measurements are taken) and circle them on Data Form 3 of the appropriate wetland subclass. To 
identify dominants, apply the 50/ 20 rule. This requires ranking species in descending order of percent cover, and then summing relative dominance in descending order until 50 percent is exceeded. Additional species with 20 percent relative dominance should also be included as dominants. Check the dominant species on Data Sheet 2. Accurate identification of woody species is critical for determining the dominant species in each plot. Sampling during the dormant season may require proficiency in recognizing plant form, bark, and dead or dormant plant parts. Users who do not feel confident in identifying trees and shrubs should seek assistance.

\section{$V_{\text {TDEN - Tree Density }}$}

Tree density is the number of trees (i.e., living woody stems greater than or equal to $10 \mathrm{~cm}$ or $4 \mathrm{in}$.) per unit area. The density of tree stems per hectare is the metric used to quantify this variable. Measure it using the following procedure:

Count the number of tree stems within the 0.04-ha plot (note: this is not the same as the stem count taken with the basal area wedge prism to determine $\mathrm{V}_{\text {TBA }}$ ). Determine carefully whether or not a tree should be counted. Measure the plot radius to all marginal trees, and include only trees having at least half the stem within the plot. Record the stem count on Data Sheet 2.

\section{$V_{W D}$ - Woody Debris Biomass and $V_{L O G}-$ Log Biomass}

Woody debris is an important habitat and nutrient cycling component of forests. Volume of woody debris and log biomass per hectare is the metric used to quantify these variables. Measure them with the procedure outlined in the following text (Brown 1974; Brown et al. 1982).

All stem diameter criteria and measurements for all size classes refer to diameter at the point of intersection with the transect line. Leaning dead stems that intersect the sampling plane are sampled. Dead trees and shrubs still supported by their roots are not sampled. Rooted stumps are not sampled, but uprooted stumps are sampled. Down stems that are decomposed to the point where they no longer maintain their shape but spread out on the ground are not sampled.

1. Lay out two $15.24-\mathrm{m}$ (50-ft) east-west transects, originating at the 0.04 -ha plot center point (Figure 14). 
2. Count the number of nonliving stems in Size Class 1 (small) (greater than or equal to $0.6 \mathrm{~cm}(0.25 \mathrm{in}$.) and less than $2.5 \mathrm{~cm}$ (1in.) that intersect a vertical plane above a 2-m (6-ft) segment of each 15.24-m (50-ft) transect. This can be any 2-m (6-ft) segment, as long as it is consistently placed. Figure 14 illustrates it as placed at the end furthest from the plot center point. Record the number of Size Class 1stems from each transect in the spaces provided on Data Sheet 2.

3. Count the number of nonliving stems in Size Class 2 (medium) (greater than or equal to $2.5 \mathrm{~cm}$ ( $1 \mathrm{in}$.) and less than $7.6 \mathrm{~cm}$ ( $3 \mathrm{in}$.) that intersect the plane above a 4-m (12-ft) segment of each 15.24-m (50-ft) transect. This can be any 4-m (12-ft) segment, as long as it is consistently placed. Figure 14 illustrates it as placed at the end furthest from the plot center point, overlapping with the 2-m (6-ft) transect segment. Record the number of Size Class 2 stems from each transect in the spaces provided on Data Sheet 2.

4. Measure and recond the diameter of nonliving stems in Size Class 3 (large) (greater than or equal to $7.6 \mathrm{~cm}$ (3 in.) that intersect the plane above the entire length of the 15.24-m (50-ft) transect. Record the diameter of individual stems (in centimeters) in Size Class 3 from each transect in the spaces provided on Data Sheet 2.

\section{Analyze Field Data}

The data recorded on the field forms must be transferred to the spreadsheet. All calculations will be made automatically, and an overall summary report will be generated. Appendix $\mathrm{C} 2$ is a facsimile of the summary report form.

\section{Document Assessment Results}

Once data collection, summarization, and analysis have been completed, it is important to assemble all pertinent documentation. Appendix A1 is a cover sheet that, when completed, identifies the assembled maps, drawings, project description, data forms, and summary sheets (including spreadsheet printouts) that are attached to document the assessment. It is highly recommended that this documentation step be completed.

\section{Apply Assessment Results}

Once the assessment and analysis phases are complete, the results can be used to compare the same WAA at different points in time, compare 
different WAAs at the same point in time, or compare different alternatives to a project. The basic unit of comparison is the FCU, but it is often helpful to examine specific impacts and mitigation actions by examining their effects on the FCI, independent of the area affected. The FCI/FCU spreadsheets are particularly useful tools for testing various scenarios and proposed actions - they allow experimentation with various alternative actions and areas affected to help isolate the project options with the least impact or the most effective restoration or mitigation approaches.

Note that the assessment procedure does not produce a single grand index of function; rather each function is separately assessed and scored, resulting in a set of functional index scores and functional units. How these are used in any particular analysis depends on the objectives of the analysis. In the case of an impact assessment, it may be reasonable to focus on the function that is most detrimentally affected. In cases where certain resources are particular regional priorities, the assessment may tend to focus on the functions most directly associated with those resources. For example, wildlife functions may be particularly important in an area that has been extensively converted to agriculture. Hydrologic functions may be of greatest interest if the project being assessed will alter water storage or flooding patterns. Conversely, this type of analysis can help recognize when a particular function is being maximized to the detriment of other functions, as might occur where a wetland is created as part of a stormwater facility; vegetation composition and structure, detritus accumulation, and other variables in such a setting would likely demonstrate that some functions are maintained at very low levels, while hydrologic functions are maximized.

Generally, comparisons can be made only between wetlands or alternatives that involve the same wetland subclass, although comparisons between subclasses can be made on the basis of functions performed rather than the magnitude of functional performance. For example, riverine subclasses have import and export functions that are not present in flats or isolated depressions. Conversely, isolated depressions are more likely to support endemic species than are river-connected systems. These types of comparisons may be particularly important where a proposed action will result in a change of subclass. When a levee, for example, will convert a riverine wetland to a flat, it is helpful to be able to recognize that certain import and export functions will no longer occur. 


\section{Special Issues in Applying the Assessment Results}

Users of this document must recognize that not all situations can be anticipated or accounted for in developing a rapid assessment method. In particular, users must be able to adapt the material presented here to special or unique situations encountered in the field. Most of the reference sites were relatively mature, diverse, and structurally complex hardwood stands. However, there are situations where relatively low diversity and different structural characteristics may be entirely appropriate, and these are generally incorporated into the subindex curves. For example, a fairly simple stand of cottonwood or willow dominating on a newly deposited bar is recognized as an appropriate $\mathrm{V}_{\text {comp }}$ condition. In other instances, however, professional judgment in the field is essential to proper application of the models. For example, some depression sites with nearpermanent flooding are dominated by buttonbush. Where this occurs because of water control structures or drainage impeded by roads, it should be recognized as having arrested functional status, at least for some functions. However, where the same situation occurs because of beaver activity or changes in channel courses, the buttonbush swamp should be recognized as a functional component of a larger wetland complex, and the VCOMP weighting system can be adjusted accordingly. Another potential way to deal with beaver in the modern landscape is to adopt the perspective that beaver complexes are fully functional but transient components of riverine wetland systems for all functions. At the same time, if beaver are not present (even in an area where they would normally be expected to occur), the resulting riverine wetland can be assessed using the models, but the overall WAA is not penalized either way. Other situations that require special consideration include areas affected by fire, sites damaged by ice storms, and similar occurrences. Fire, in particular, can cause dramatic short-term changes in many of the indicators measured to assess function, such as ground cover, woody debris, and litter accumulation. Note, however, that normal, non-catastrophic disturbances to wetlands (i.e., tree mortality causing small openings) are accounted for in the reference data used in this guidebook.

The assessment models and procedures presented in this guidebook are applicable to the vast majority of the wetlands that exist within alluvial valleys of East Texas. However, the classification system presented in Chapter 3 includes a number of wetland subclasses that may occur within the reference domain, but are not specifically covered by this guidebook. Users of this guidebook may be faced with situations where they need to 
draw some conclusions regarding the effects of proposed actions on these excluded systems. The discussion of their characteristics presented in Chapter 3 is provided specifically to assist users who encounter these uncommon or unique systems, and more specific guidance is provided as follows:

a. The fringe subclasses are excluded primarily because they are not well suited to rapid assessment approaches (particularly reservoir sites, where no natural corollary exists to establish reference conditions and criteria). Proposals to modify, eliminate, or create fringe wetlands should be evaluated in detail, with attention to substrate type, water depths, and particularly, to hydrologic regime. Typically, man-made reservoirs are designed specifically to modify natural hydrologic patterns, and as such cannot be directly compared to any natural system. The characteristics and functionality of such systems can only be estimated by evaluating similar, established projects in the vicinity.

b. Slope wetlands were excluded as not being associated with alluvial surfaces, and because they almost always should be regarded as "Red Flag" resources not subject to functional assessment due to the presence of rare species and communities. In the event that a functional assessment of slope wetlands is required, the models and reference data provided for the coastal plain region of Arkansas (Klimas et al. 2005) are reasonably applicable to the types of slope wetlands found in East Texas, and may be used judiciously.

c. Within the reference domain, forested alluvial settings that are not within the 5-year floodplain are so uncommon that sufficient reference data could not be collected to develop calibrated models for the flat and unconnected depression wetland subclasses. However, limited observation of these systems and more extensive reference data collected in the nearby coastal plain region of Arkansas (Klimas et al. 2005) indicate that they are similar in most structural and compositional aspects to their more frequently flooded counterparts (low-gradient riverine and connected depression subclasses). The principal difference between them is the extent of their interaction with stream systems, as represented by flood frequency. Therefore, if it is necessary to assess a flat or unconnected depression, the riverine backwater and connected depression models can be adapted to that purpose. Certain functions (carbon export and floodwater attenuation) 
are not assessed in the unflooded subclasses, and the remaining models can be adapted by removing the flood frequency and duration variables, and adjusting the equations appropriately (i.e., change divisors, etc.).

Another potential consideration in the application of the assessment models presented here concerns the projection of future conditions. This may be particularly important in determining the rate at which functional status will improve as a result of restoration actions intended to offset impacts to jurisdictional wetlands. The graphs in Figure 17 represent general recovery trajectories for forested hardwood wetlands within alluvial valleys of East Texas based on a subset of the reference data collected to develop this guidebook. In selected stands, individual trees were aged using an increment corer to develop a general relationship between the age of sampled stands and the site-specific variables employed in the assessment models. Thus, a user can estimate the overstory basal area, shrub density, woody debris volume, and other functional indicators for various time intervals, and calculate FCIs for all assessed functions. These curves are specifically constructed to reflect wetland recovery following restoration of agricultural land. Therefore, they assume that the initial site condition includes bare ground that has been tilled. Varying degrees and types of tillage within reference areas confuse recovery patterns for soil development; therefore, no trajectory curve is presented for $\mathrm{V}_{\mathrm{AHOR}}$. Users should base projections for this variable on the initial site condition, or modify the assessment equations so that this variable is not considered in future projections. Note that landscape variables are not included here, because they require site-specific knowledge to project future conditions. Ponding development rates also are not estimated, because ponding is the result of both geomorphic and biotic factors and the initial site conditions (i.e., extent of land leveling). The degree of microtopographic relief will be dependent on the extent of site contouring work done prior to planting, in most cases. Similarly, the rates of compositional change ( $\mathrm{V}_{\text {COMP }}$ and $\mathrm{V}_{\mathrm{TCOMP}}$ ) are dependent on initial site conditions. Generally, a site planted with appropriate species should have an FCI score of 1.0 soon after planting for the compositional variable $V_{\mathrm{COMP}}$, and maintain that fully functional status indefinitely as $\mathrm{V}_{\mathrm{TCO} P \mathrm{P}}$ becomes the applicable compositional variable. Estimation of future composition for unplanted areas will require sitespecific evaluation of seed sources and probable colonization patterns.

Note also that the graphs in Figure 17 are amalgams of data from all wetland subclasses. In situations where a site is expected to be unusual in 
one or more respects (such as a cottonwood stand, where basal areas are likely to increase more quickly than in hardwood forests), more specific data may exist, and should be substituted for these general curves, as appropriate. Similarly, the influence of fire is not assumed. Changes to system characteristics depicted in the graphs reflect conditions where fire has been suppressed, as it has in the majority of the reference sites.

Often, the methods and assumptions presented in this guidebook must be adapted to particular situations, and the user can do so as long as all revisions and new assumptions are fully documented. One situation where case-by-case adaptation is likely to be needed concerns greentree reservoirs. As currently configured, the assessment models assume that greentrees within riverine wetlands will remain riverine (i.e., the impounding levees will not be an impediment to the exchange of floodwater, fish, and organic material between the forest and the stream system). In fact, this may be the case for some situations where the greentree is actually part of a larger flood-control unit, or it is filled by closing gates in a stream channel rather than pumping. But when the greentree actually functions as an off-channel impoundment, and does not interact with the stream system, it should probably be viewed as having lost the river-connection component of the export, flood detention, and fish habitat functions. Most other wildlife functions remain, however (indeed, the point of greentree reservoirs is to maximize waterfowl use). 


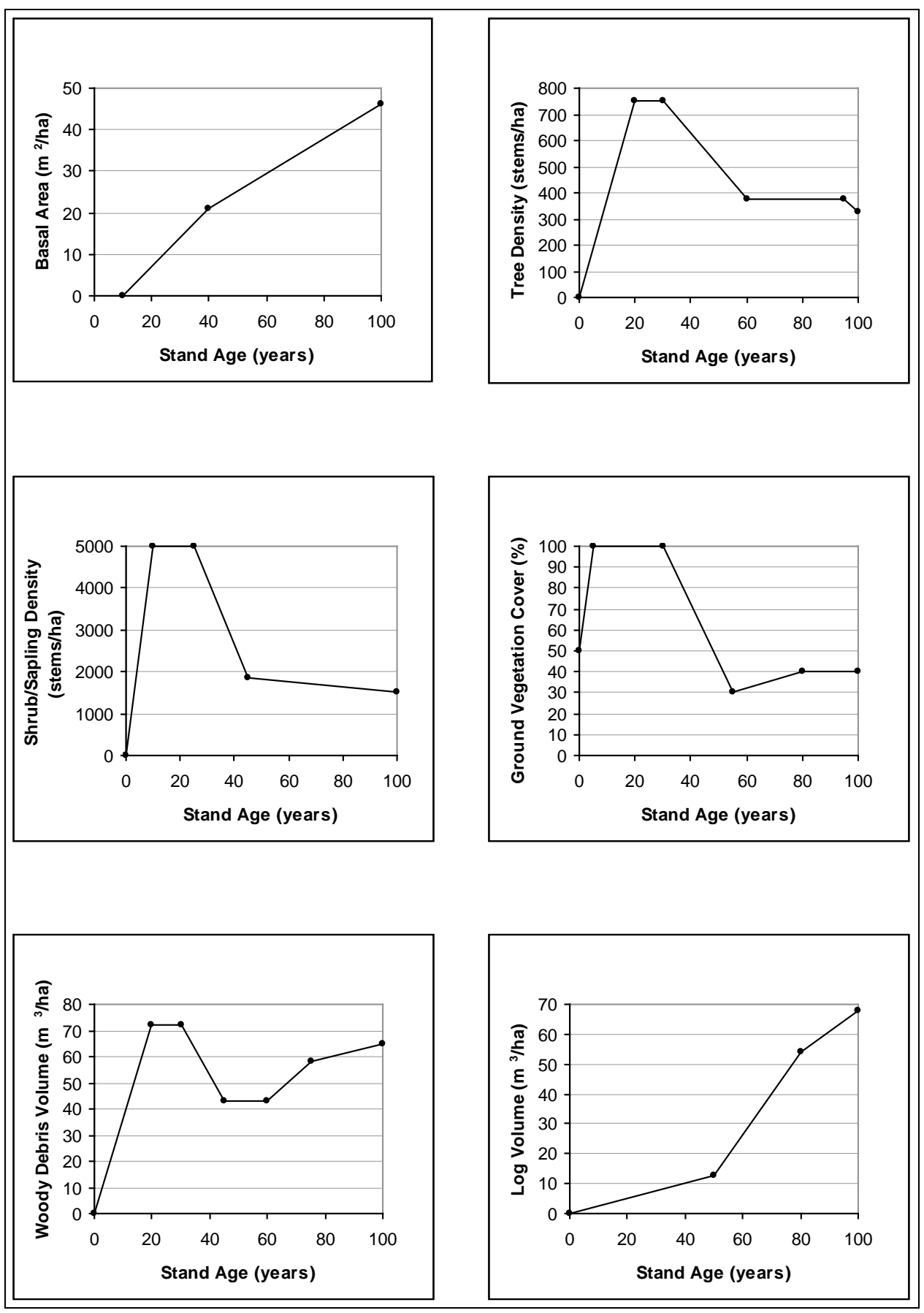

Figure 17. Projected recovery trajectories for selected assessment variables (Continued). 


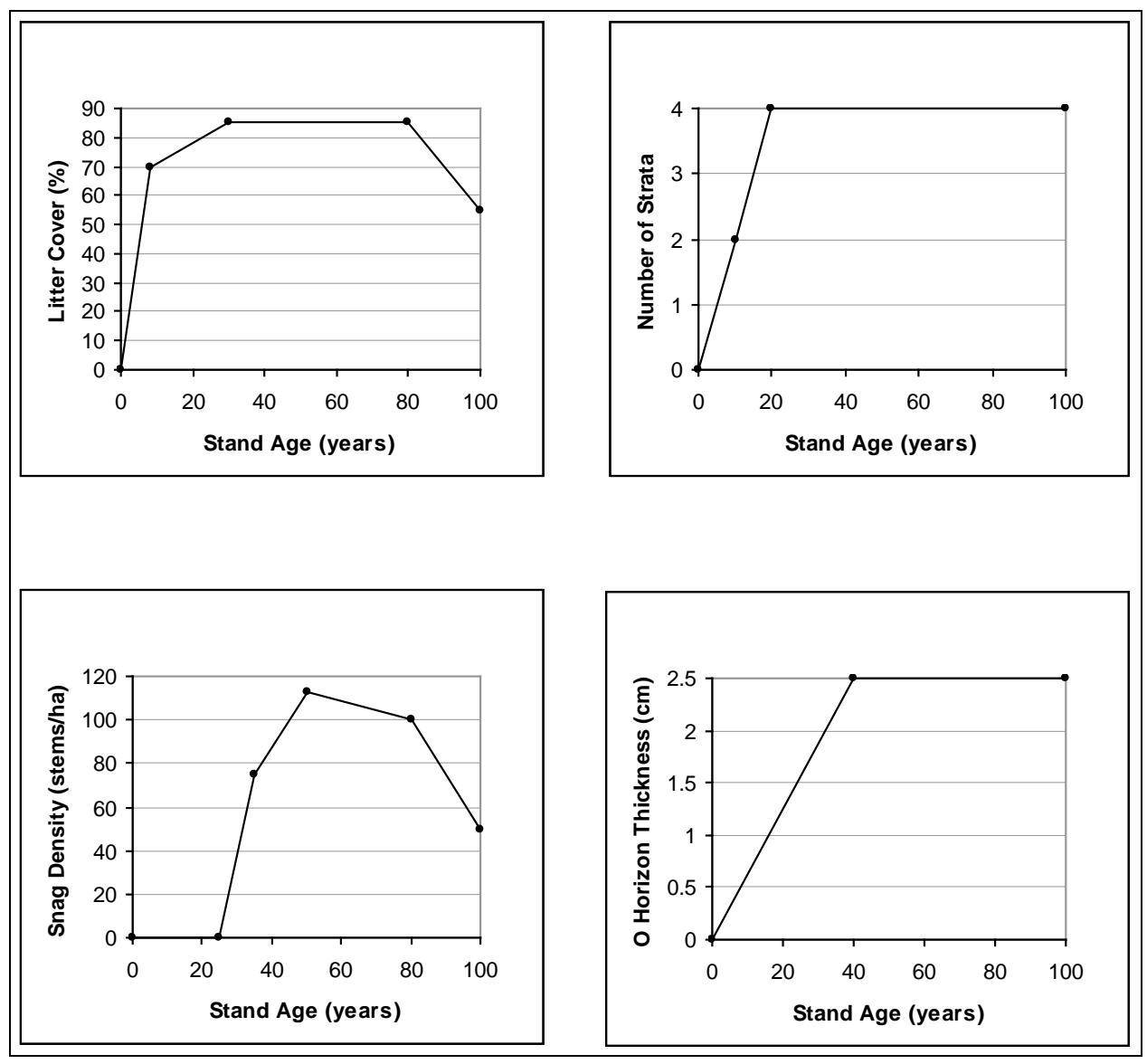

Figure 17. (Concluded) 


\section{References}

Ainslie, W. B., R. D. Smith, B. A. Pruitt, T. H. Roberts, E. J. Sparks, L. West, G. L. Godshalk, and M. V. Miller. 1999. A regional guidebook for assessing the functions of low gradient, riverine wetlands of western Kentucky. Technical Report WRP-DE-17. Vicksburg, MS: U.S. Army Engineer Waterways Experiment Station.

Allen, A. W. 1987. Habitat suitability index models: Gray squirrel, revised. Biological Report 82(10.135). U.S. Fish and Wildlife Service.

Bailey, M. A., and K. A. Bailey. 2000. Wetland fauna and drainage basin studies: Amphibian and reptile habitat utilization. Arnold Engineering Development Center, Arnold Air Force Base, TN.

Bailey, R. G. 1995. Description of the Ecoregions of the United States, 2nd ed. rev. and expanded (1st ed. 1980). Misc. Publ. No. 1391 (rev.), Washington DC: USDA Forest Service. 108 p. with separate map at 1:7,500,000.

Baker, J . A., and K. J . Killgore. 1994. Use of a flooded bottomland hardwood wetland by fishes in the Cache River System, Arkansas. Technical Report WRP-CP-3. Vicksburg, MS: U.S. Army Engineer Waterways Experiment Station.

Barrow, W. C., Jr. and I. Renne. 2001. Interactions between migrant landbirds and an invasive exotic plant: the Chinese tallow tree. Flyway newsletter 8:11.

Bicknell, B. R., J . C. Imhoff, J . L. Kittle, A. S. Donigan, and R. C. J ohanson. 1993. Hydrologic Simulation Program - Fortran (HSPF): User's manual for release 10.0. EPA 600/3-84-066. Athens, GA: Environmental Research Laboratory.

Bormann, F. H., and G. E. Likens. 1970. The nutrient cycles of an ecosystem. Scientific American 223: 92- 101.

Bovee, K. D. 1982. A guide to stream habitat analysis using the in stream flow incremental methodology. Instream Flow Information Paper No. 12, OBS-82/ 26. Washington, DC: U.S. Fish and Wildlife Service, Office of Biological Services.

Boyd, L. 2001. Wildlife use of wetland buffer zones and their protection under the Massachusetts Wetland Protection Act. Department of Natural Resources Conservation, University of Massachusetts.

Bridge, J . S. 2003. Rivers and floodplains: Forms, processes, and sedimentary record. Malden, MA: Blackwell Publishing Company.

Brinson, M. M. 1990. Riverine forests. In Forested Wetlands, ed. A. E. Lugo, M. M. Brinson, and S. Brown, 87-141. Amsterdam: Elsevier Scientific Publishers.

. 1993a. A hydrogeomorphic classification for wetlands. Technical Report WRP-DE-4. Vicksburg, MS: U.S. Army Engineer Waterways Experiment Station. 
. 1993b. Changes in the functioning of wetlands along environmental gradients. Wetlands 13: 65- 74.

Brinson, M. M., A. E. Lugo, and S. Brown. 1981. Primary productivity, decomposition and consumer activity in freshwater wetlands. Annual Review of Ecology and Systematics 12: 123-61.

Brinson, M. M., F. R. Hauer, L. C. Lee, W. L. Nutter, R. D. Rheinhardt, R. D. Smith, and D. Whigham. 1995. A guidebook for application of hydrogeomorphic assessments to riverine wetlands. Technical Report WRP-DE-1. Vicksburg, MS: U.S. Army Engineer Waterways Experiment Station.

Brinson, M. M., W. L. Nutter, R. Rheinhardt, R., and B. A. Pruitt. 1996. Background and recommendations for establishing reference wetlands in the Piedmont of the Carolinas and Georgia. EPA/ 600/R-96/ 057. Corvallis, OR: U.S. Environmental Protection Agency National Health and Environmental Effects Laboratory, Western Division.

Brinson, M. M., R. D. Smith, D. F. Whigham, L. C. Lee, R. D. Rheinhardt, and W. L. Nutter. 1998. Progress in development of the hydrogeomorphic approach for assessing the functioning of wetlands. In Proceedings, INTECOL International Wetland Conference. Perth, Australia.

Brooks, K. N., P. F. Folliott, H. M. Gregerson, and J. L. Thames. 1991. Hydrology and the management of watersheds. Ames, IA: Iowa State University Press.

Brown, J. K. 1974. Handbook for inventorying downed woody material. General Technical Report INT-16. Ogden, UT: U.S. Department of Agriculture Forest Service.

Brown, J . K., R. D. Oberheu, and C. M. J ohnston. 1982. Handbook for inventorying surface fuels and biomass in the Interior West. General Technical Report INT129. Ogden UT: U.S. Department of Agriculture Forest Service Inter-mountain Forest and Range Experiment Station.

Brown, S., and D. L. Peterson. 1983. Structural characteristics and biomass production of two Illinois bottomland forests. American Midland Naturalist 110: 107- 17.

Bruce, K. A., G. N. Cameron, P. A. Harcombe, and G. J ubinsky. 1997. Introduction, impact on native habitats, and management of a woody invader, the Chinese tallow tree (Sapium sebiferum (L) Roxb). Natural Areas J ournal 17: 255-260.

Bureau of Economic Geology. 1992. Geology of Texas (Map). Bureau of Economic Geology, The University of Texas, Austin, TX. 06 November 2008. $<$ http://www.lib.utexas.edu/geo/map.html>.

Burke, V. J ., and J . W. Gibbons. 1995. Terrestrial buffer zones and wetland conservation: A case study of freshwater turtles in a Carolina bay. Conservation Biology 9: 1365- 1369.

Campbell, K. L., and H. P. J ohnson. 1975. Hydrologic simulation of watersheds with artificial drainage. Water Resources Research 11: 120- 26. 
Conner, W. H., and J . W. Day, Jr. 1976. Productivity and composition of a baldcypresswater tupelo site and bottomland hardwood site in a Louisiana swamp. American J ournal of Botany 63: 1354-64.

Cowardin, L. M, V. Carter, F. C. Golet, and E. T. LaRoe. 1979. Classification of wetlands and deep-water habitats of the United States. FWS/ OBS-79/31. Washington, DC: Office of Biological Services, U.S. Fish and Wildlife Service.

Dahm, C. M. 1981. Pathways and mechanisms for removal of dissolved organic carbon from leaf leachates in streams. Canadian J ournal of Fish and Aquatic Science 38: 68- 76 .

Day, F. P. 1979. Litter accumulation in four plant communities in the Dismal Swamp, Virginia. American Midland Naturalist 102: 281- 89.

Demissie, M., and A. Kahn. 1993. Influence of wetlands on streamflow in Illinois. Contract Report 561. Champaign, IL: Illinois State Water Survey.

Dewey and Kropper Engineers. 1964. Effect of loss of valley storage due to encroachment-Connecticut River. Report to the Water Resources Commission, Hartford, CT.

Dickinson, C. H., and G. Pugh. 1974. Biology of plant litter decomposition, Volume I., London, England: Academic Press.

Diggs, G. M., J r., B. L. Lipscomb, M. D. Reed, and R. J . O'Kennon. 2006. Illustrated Flora of East Texas. Volume One: Introduction, Pteridophytes, Gymnosperms, and Monocotyledons. Sida, Botanical Miscellany, No. 26. Botanical Institute of Texas and Austin College Publishers.

Dumble, E. T. 1918. The Geology of East Texas. University of Texas Bulletin No. 1869: December 10, 1918. Bureau of Economic Geology and Technology.

Dunne, T., and L. B. Leopold. 1978. Water in environmental planning. San Francisco, CA: W. H. Freeman and Company.

Edwards, R. T. 1987. Sestonic bacteria as a food source for filtering invertebrates in two southeastern blackwater streams. Limnology and Oceanography 32: 221- 34.

Elder, J . F., and H. Mattraw. 1982. Riverine transport of nutrients and detritus to the Apalachicola Bay Estuary, Florida. Water Resources Bulletin 18: 849- 56.

Elwood, J . W., J . D. Newbold, R. V. O'Neill, and W. Van Winkle, W. 1983. Resource spiraling: An operational paradigm for analyzing lotic ecosystems. In Dynamics of lotic ecosystems, ed. T. D. Fontaine and S. M. Bartell. Ann Arbor, MI: Ann Arbor Science.

Estes, C. C., and J . F. Orsborn. 1986. Review and analysis of methods for quantifying instream flow requirements. Water Resources Bulletin 22: 389-98.

Fredrickson, L. H. 1978. Lowland hardwood wetlands: current status and habitat values for wildlife. In Wetland functions and values: The state of our understanding, ed. P. E. Greeson, J . R. Clark, and J . E. Clark, 207-306. Minneapolis, MN: American Water Resources Association. 
German, D. 2005. Pineywoods mitigation and conservation area baseline vegetation survey. Austin, TX: Texas Parks and Wildlife Department.

Gibbons, J . W. 2003. Terrestrial habitat: A vital component for herpetofauna of isolated wetlands. Wetlands 23: 630- 635.

Gibbons, J . W., and K. A. Buhlmann. 2001. Reptiles and amphibians. In Wildlife of Southern Forests, Habitat and Management, ed. J . G. Dickson, 372-390. Blaine, WA: Hancock House Publishers.

Golet, F. C., and J . S. Larson. 1974. Classification of freshwater wetlands in the glaciated Northeast. Resource Publication 116. U.S. Fish and Wildlife Service.

Harmon, M. E., J . F. Franklin, and F. J . Swanson. 1986. Ecology of coarse woody debris in temperate ecosystems. Advances in Ecological Research 15: 133- 302.

Harris, L. D., and J . G. Gosselink. 1990. Cumulative impacts of bottomland hardwood forest conversion on hydrology, water quality, and terrestrial wildlife. In Ecological processes and cumulative impacts illustrated by bottomland hardwood wetland ecosystems, ed. J . G. Gosselink, L. C. Lee, and T. A. Muir, 259-322. Chelsea, MI: Lewis Publishers.

Hauer, F. R., and R. D. Smith. 1998. The hydrogeomorphic approach to functional assessment of riparian wetlands: Evaluating impacts and mitigation on river floodplains in the U.S.A. Freshwater Biology 40: 517- 30.

Hayes, A. J . 1979. The microbiology of plant litter decomposition. Scientific Progress 66: 25- 42 .

Heitmeyer, M. E., and B. Ederington. 2004. An evaluation of bottomland hardwood forests in the Bayou Meto Basin Improvement Project area. Report to Memphis District, Corps of Engineers.

Hodges, J . D. 1997. Development and ecology of bottomland hardwood sites. Forest Ecology and Management 90: 117- 25.

Hodges, J . D. 1998. Chapter 13. Minor alluvial floodplains. In Southern forested wetlands: Ecology and management, ed. M. G. Messina and W. H. Conner, 325342. Boca Raton, FL: Lewis Publishers, CRC Press LLC.

Howard, R. J ., and J . A. Allen. 1989. Streamside habitats in southern forested wetlands: Their role and implications for management. In Proceedings of the symposium: The forested wetlands of the southern United States, ed. D. D. Hook and R. Lea, General Technical Report SE-50. U.S. Department of Agriculture Forest Service.

Hunter, M. L. 1990. Wildlife, forests, and forestry: Principles of managing forests for biological diversity. Englewood Cliffs, NJ : Prentice Hall.

Hunter, W. C., J . G. Dickson, D. N. Pashley, and P. B. Hamel. 2001. Bird communities of southern forests. In Wildlife of southern forests, habitat and management, ed. J . G. Dickson, 322-349. Blaine, WA: Hancock House Publishers.

Hydrologic Engineering Center. 1981. HEC-1 flood hydrograph package. User's manual. U.S. Army Corps of Engineers, Davis, CA. 
. 1982. HEC-2 water surface profiles. User's manual. U.S. Army Corps of Engineers, Davis, CA.

. 1997. HEC- RAS river analysis system. User's manual. U.S. Army Corps of Engineers, Davis, CA.

Jennings, M. E., W. O. Thomas, J r., and H. C. Riggs. 1994. Nationwide summary of U.S. Geological Survey regional regression equations for estimating magnitudeand frequency of floods for ungaged sites, 1993. Water Resources Investigations Report 94-4002. U.S. Geological Survey.

J ohnson, T. R. 1987. The amphibians and reptiles of Missouri. J efferson City, MO: Missouri Department of Conservation.

J ohnston, C. A., N. E. Detenbeck, and G. J . Niemi. 1990. The cumulative effect of wetlands on stream water-quality and quantity: A landscape approach. Biogeochemistry 10: 105- 41.

Kellison, R. C., M. J . Young, R. R. Braham, and E. J . J ones. 1998. Chapter 12: Major Alluvial Floodplains. In Southern forested wetlands, ecology and management, ed. M. G. Messina and W. H. Conner, 291-324. Boca Raton, FL: Lewis Publishers, CRC Press LLC.

Klimas, C. V., E. O. Murray, J. Pagan, H. Langston, and T. Foti. 2004. A regional guidebook for applying the hydrogeomorphic approach to assessing wetland functions of forested wetlands in the Delta Region of Arkansas, Lower Mississippi River Alluvial Valley. ERDC/ EL TR-04-16. Vicksburg, MS: U.S. Army Engineer Research and Development Center.

Klimas, C. V., E. O. Murray, J. Pagan, H. Langston, and T. Foti. 2005. A regional guidebook for applying the hydrogeomorphic approach to assessing wetland functions of forested wetlands in the West Gulf Coastal Plain Region of Arkansas. ERDC/ EL TR-05-12. Vicksburg, MS: U.S. Army Engineer Research and Development Center.

Klimas, C. V., E. O. Murray, H. Langston, T. Witsell, and T. Foti. 2006. A regional guidebook for applying the hydrogeomorphic approach to assessing functions of forested wetlands and Riparian Areas in the Ouachita Mountains and Crowley's Ridge Regions of Arkansas. ERDC/ EL TR-05-12. Vicksburg, MS: U.S. Army Engineer Research and Development Center.

Klimas, C.V., E.O. Murray, T. Foti, J . Pagan, M. Williamson, and H. Langston. 2009. An ecosystem restoration model for the Mississippi Alluvial Valley based on geomorphology, hydrology, and soils. Wetlands 29:430-450.

Leopold, L. B. 1994. A view of the river. Cambridge, MA: Harvard University Press.

Loeb, S. C. 1993. The role of coarse woody debris in the ecology of southeastern mammals. In Biodiversity and coarse woody debris in southern forests. GTRSE-94, 108-118, ed. J . W. McMinn and D. A. Crossley. U.S. Department of Agriculture Forest Service Southern Research Station.

Matos, J. A., and D. C. Rudolph. 1985. The vegetation of the Roy E. Larsen Sandylands Sanctuary in the Big Thicket of Texas. Castanea 50: 228-249. 
McMahan, C. A., R. G. Frye, and K. L. Brown. 1984. The vegetation types of Texas Including cropland: An illustrated synopsis to accompany the map. PittmanRobertson Project W-107-R. Austin, TX: Texas Parks and Wildlife Department, Wildlife Division.

McWilliams, S. R., and M. D. Bachman. 1988. Using life history and ecology as tools to manage a threatened salamander species. J . Iowa Acad. Sci. 95: 66- 71.

Messina, M. G., and W. H. Conner. 1997. Southern forested wetlands: Ecology and management. Boca Raton, FL: Lewis Publishers.

Meyer, J . L., L. A. Kaplan, D. Newbold, D. L. Strayer, C. J . Woltemade, J . B. Zedler, R. Beilfus, Q. Carpenter, R. Semlitsch, M. C. Watzin, and P. H. Zedler. 2003. Where rivers are born. American Rivers and The Sierra Club.

Miller, B. T. 1995. An investigation of rare, threatened, and endangered fauna and their habitats on Arnold Air Force Base, Coffee and Franklin Counties, Tennessee: Amphibian and reptile survey. Middle Tennessee State University, Murfreesboro.

Miller, J . H. 2003. Nonnative invasive plants of southern forests: A field guide for identification and control. Revised. Gen. Tech. Rep. SRS-62. Asheville, NC: U.S. Department of Agriculture, Forest Service, Southern Research Station.

Mitch, P. P., and J. G. Gosselink. 1993. Wetlands. New York: Van Nostrand Reinhold.

Morrison, M. L., B. C. Marcot, and R. W. Mannan. 1992. Wildlife-habitat relationships: Concepts and applications. Madison, WI: University of Wisconsin Press.

Mulholland, P. J . 1981. Organic carbon flow in a swamp-stream ecosystem. Ecological Monographs 51: 307- 32.

Mulholland, P.J ., and E. J . Kuenzler. 1979. Organic-carbon export from upland and forested wetland watersheds. Limnology and Oceanography 24: 960-66.

National Interagency Implementation Team. 1996. National action plan to implement the hydrogeomorphic approach (NAP). Federal Register 61(160): 42593- 42603. Washington, DC.

Nixon, E. S., R. W. Willett, and P. W. Cox. 1977. Woody vegetation of a virgin forest in an eastern Texas river bottom. Castanea 42: 227-236.

Novitski, R. P. 1978. Hydrogeological characteristics of Wisconsin's wetlands and their influences on floods, stream flow, and sediment. In Wetland functions and values: The state of our understanding, ed. P. E. Greeson, J . R. C. Clark, and J . E. Clark, 377- 388. Minneapolis, MN: American Water Resources Association.

Natural Resources Conservation Service (NRCS). 1995. Natural Resources Conservation Service. WETS Table Documentation. 24 October 2008.

$<$ http://www.wcc.nrcs.usda.gov/climate/wets_doc.html >.

Ogawa, H., and J. W. Male. 1983. The flood mitigation potential of inland wetlands. Publication Number 138. Amherst, MA: Water Resources Center. 
. 1986. Simulating the flood mitigation role of wetlands. J ournal of Water Resources Planning and Management, ASCE, 112: 114- 128.

Ovington, J . D. 1965. Organic production, turnover and mineral cycling in woodlands. Biological Review 40: 772- 785.

Patton, P. C. 1988. Drainage basin morphometry and floods. In Flood geomorphology, ed. V. R. Baker, R. C. Kochel, and P. C. Patton, 51- 64. New York: J ohn Wiley.

Perry, D. A. 1994. Forest ecosystems. Baltimore, MD: J ohns Hopkins University Press.

Phillips, J . D. 2003. Toledo Bend Reservoir and geomorphic response in the lower Sabine River. River Res. Applic. 19: 137-159.

Pirkle, E. C. and Yoho, W. H. 1977. Natural Regions of the United States, 2nd ed. Dubuque, IA: Kendall/ Hunt Publishing Co.

Pomeroy, L. R. 1970. The strategy of mineral cycling. Annual Review of Ecology and Systematics 1: 171- 190.

Pugh, G., and C. H. Dickinson. 1974. Biology of plant litter decomposition. Volume II. London: Academic Press.

Reiners, W. A. 1972. Terrestrial detritus and the carbon cycle. In Carbon and the biosphere, Conference Proceedings 720510, ed. G. M. Woodwell and E. V. Pecan. U.S. Atomic Energy Commission.

Rheinhardt, R. D., M. M. Brinson, and P. M. Farley. 1997. Applying wetland reference data to functional assessment, mitigation, and restoration. Wetlands 17: 195- 215.

Ritter, D. F., R. C. Kochel, and J . R. Miller. 1995. Process geomorphology. $3^{\text {rd }}$ ed. Chicago, IL: William C. Brown.

Robertson, P. A. 1992. Environmental factors affecting tree grouth on three wetland sites in southern Illinois. American Midland Naturalist 128: 218- 326.

Robertson, P. A., G. T. Weaver, and J . A. Cavanaugh. 1978. Vegetation and tree species patterns near the northern terminus of the southern floodplain forest. Ecological Monographs 48: 249- 267.

Robertson, P. A., M. D. MacKenzie, and L. F. Elliot. 1984. Gradient analysis and classification of the woody vegetation for four sites in southern Illinois and adjacent Missouri. Vegetatio 58: 87- 104.

Robinson, S. K. 1996. Setting objectives in forested habitats. Presentation, Partners in Flight, Midwest and Southern Great Plains Workshop, April 8, 1996, St. Louis, MO.

Robinson, S. K., F. R. Thompson III, T. M. Donovan, D. R. Whitehead, and J . Faaborg. 1995. Regional forest fragmentation and the nesting success of migratory birds. Science 267: 1987-90. 
Rothermel, B. B., and R. D. Semlitsch. 2002. An experimental investigation of landscape resistance of forest versus old-field habitats to emigrating juvenile amphibians. Conservation Biology 16: 1324- 1332.

Rudis, V. A., B. Carraway, R. M. Sheffield, S. N. Oswalt, and J . L. Chamberlain. 2003. East Texas forests, 2003. Resour. Bull. SRS-137. Asheville, NC: U. S. Department of Agriculture Forest Service, Southern Research Station.

Sallabanks, R., J . R. Walters, and J . A. Collazo. 1998. Breeding bird abundance in bottomland forests: Habitat, edge, and patch size effects. Condor 102: 748- 58.

Saucier, R. T. 1994. Geomorphology and quaternary geologic history of the Lower Mississippi Valley, Vol I (report), Vol II (map folio). Vicksburg MS: U.S. Army Engineer Waterways Experiment Station.

Schlesinger, W. H. 1977. Carbon balance in terrestrial detritus. Annual Review of Ecology and Systematics 8: 51- 81.

Schlosser, I. J . 1991. Stream fish ecology: A landscape perspective. Bioscience 41: 704712.

Schoener, T. W. 1986. Resource partitioning. In Community ecology: Patterns and processes, ed. J . Kikkawa and D. J . Anderson, 91-126. Melbourne, Australia: Blackwell.

Sedell, J . R., J . E. Richey, and F. J . Swanson. 1989. The river continuum concept: A basis for the expected ecosystem behavior of very large rivers. Canadian J ournal of Fisheries and Aquatic Science 46: 49- 55.

Semlitsch, R. D. 1998. Biological delineation of terrestrial buffer zones for pond-breeding salamanders. Conservation Biology 12: 1113-1119.

Semlitsch, R. D. and J . R. Bodie. 1998. Are small, isolated wetlands expendable? Conservation Biology 12: 1129- 1133.

Semlitsch, R. D., and J. B. J ensen. 2001. Core habitat, not buffer zone. National Wetlands Newsletter 23: 5- 11.

Shafer, D. J., and Yozzo, D. J . 1998. National guidebook for application of hydrogeomorphic assessment to tidal fringe wetlands. Technical Report WRPDE-16. Vicksburg, MS: U.S. Army Engineer Waterways Experiment Station.

Singh, J. S., and S. R. Gupta. 1977. Plant decomposition and soil respiration in terrestrial ecosystems. Botanical Review 43: 449-528.

Smith, R. D. 1996. Composition, structure, and distribution of woody vegetation on the Cache River floodplain, Arkansas. Wetlands 16: 264-278.

2001. Hydrogeomorphic approach to assessing wetland functions: Guidelines for developing regional guidebooks. Chapter 3: Developing the reference wetland system. ERDC/ EL TR-01-29. Vicksburg, MS: U.S. Army Engineer Research and Development Center. 
Smith, R. D., and C. V. Klimas. 2002. A regional guidebook for applying the hydrogeomorphic approach to assessing wetland functions of selected regional wetland subclasses, Yazoo Basin, Lower Mississippi River Alluvial Valley. ERDC/ EL TR-02-4. Vicksburg, MS: U.S. Army Engineer Research and Development Center.

Smith, R. D., A. A. Ammann, C. Bartoldus, and M. M. Brinson. 1995. An approach for assessing wetland functions using hydrogeomorphic classification, reference wetlands, and functional indices. Wetlands Research Program Technical Report WRP-DE-9. Vicksburg, MS: U.S. Army Engineer Waterways Experiment Station.

Spearing, D. 1991. Roadside Geology of Texas. Mountain Press Publishing Company, Missoula, MT.

Spurr, S. H., and Barnes, B. V. 1981. Forest ecology. New York: J ohn Wiley.

Stanford, J . A., J . V. Ward, W. J . Liss, C. A. Frissell, R. N. Williams, J . A. Lichatowich, and C. C. Coutant. 1996. A general protocol for restoration of regulated rivers. Regulated Rivers Research and Management 12: 391- 413.

Stauffer, D. F., and L. B. Best. 1980. Habitat selection by birds of riparian communities evaluating effects of habitat alterations. J ournal of Wildlife Management 44: 1115.

Stewart, R. E., and H. A. Kantrud. 1971. Classification of natural ponds and lakes in the glaciated prairie region. Resource Publication 92. Washington, DC: U.S. Fish and Wildlife Service.

Texas Commission on Environmental Quality (TCEQ). 2004. Atlas of Texas Surface Waters. Maps of the Classified Segments of Texas River and Coastal Basins. Texas Commission on Environmental Quality. GI-316/ August 2004.

Texas Parks and Wildlife Department. 2009. River Basins of Texas; Vegetation Types of Texas (online maps). Available from: http://www.tpwd.state.tx.us/landwater/land/maps/gis/map_downloads/map_gallery/ (Accessed J anuary 2009).

Texas Water Development Board (TWDB). 2007. 2007 State Water Plan. Texas Water Development Board. 3 November 2008. $\measuredangle$ ttp://www.twdb.state.tx.us/wrpi/swp/swp.htm>.

Texas Water Development Board (TWDB). 2009. Major Aquifers of Texas; Minor Aquifers of Texas (online maps). Available from: http://www.twdb.state.tx.us/mapping/index.asp\#Maps_Top (Accessed J anuary 2009).

Terry, J . E., R. L. Hosman, and C. T. Bryant. 1979. Summary appraisals of the nation's ground-water resources - Lower Mississippi Region. U.S. Geological Survey Professional Paper 813-N.

Thomas, D. M., and M. A. Hanson. 1981. Generalization of streamflow characteristics from drainage-basin characteristics. Water Supply Paper 1-55. Washington, DC: U.S. Geological Survey. 
Thompson, F. R., III, W. D. Dijak, T. G. Kulowiec, and D. A. Hamilton. 1992. Breeding bird populations in Missouri Ozark forests with and without clearcutting. J ournal of Wildlife Management 56: 23- 30.

U.S. Department of Agriculture (USDA), Soil Conservation Service. 1993. Soil survey manual. U.S. Department of Agriculture Handbook 18. Washington, DC: U.S. Government Printing Office.

U.S. Environmental Protection Agency (USEPA). 2009. Ecoregions of Texas (online map). Available from: http://www.epa.gov/wed/pages/ecoregions/tx_eco.htm (Accessed January 2009).

Van Kley, J . E., and D. N. Hine. 1998. The wetland vegetation of Caddo Lake. Texas J . of Sci. 50: 267-290.

Van Kley, J. 2006. The Pineywoods. In Illustrated Flora of East Texas. Volume One: Introduction, Pteridophytes, Gymnosperms, and Monocotyledons, ed. Diggs, J r., G. M., B. L. Lipscomb, M. D. Reed, and R. J . O'Kennon, 76-106. Sida, Botanical Miscellany, No. 26. Botanical Institute of Texas and Austin College Publishers.

Vannote, R. L., G. W. Minshall, K. W. Cummins, J . R. Sedell, and C. E. Cushing. 1980. The river continuum concept. Canadian J ournal of Fisheries and Aquatic Sciences 37: 130- 37.

Vogt, K. A., C. C. Grier, and D. J . Vogt. 1986. Production, turnover, and nutrient dynamics of above and belowground detritus of world forests. Advances in Ecological Research 15: 303- 77.

Weller, M. W. 1989. Plant and water-level dynamics in an east Texas shrub/ hardwood bottomland wetland. Wetlands 9: 73-88.

Welsh, C. J. E., and W. M. Healy. 1993. Effect of even-aged timber management on bird species diversity and composition in northern hardwoods of New Hampshire. Wildlife Society Bulletin 21: 143- 54.

Wharton, C. H., W. M. Kitchens, E. C. Pendleton, and T. W. Sipe. 1982. The ecology of bottomland hardwood swamps of the Southeast: A community profile. Report FWS/ OBS-81/37. Washington, DC: Office of Biological Services, U.S. Fish and Wildlife Service.

Whittaker, R. H. 1975. Communities and ecosystems. New York: MacMillan.

Williams, B., D. J ohns, H. Williams, and W. Ledbetter. 2002. Converting pine plantations to bottomland hardwood forests: A case study from east Texas. Ecological Restoration 20: 88-95.

Wohl, E. 2000. Mountain rivers. Water Resources Monograph 14. Washington DC: American Geophysical Union. 


\section{Appendix A: Preliminary Project Documentation and Field Sampling Guidance}

\section{Contents}

Appendix A1. Site or Project Information and Assessment Documentation

Appendix A2. Field Assessment Preparation Checklist including list of data forms

Appendix A3. Layout of Plots and Transects for Field Sampling

Please reproduce these forms locally as needed. 


\section{SITE or PROJECT INFORMATION and ASSESSMENT DOCUMENTATION}

(Complete one form for entire site or project area)

Date:

Project/Site Name:

Person(s) involved in assessment:

Field

Computations/summarization/quality control

The following checked items are attached:

A description of the project, including land ownership, baseline conditions, proposed actions, purpose, project proponent, regulatory or other context, and reviewing agencies.

Maps, aerial photos, and /or drawings of the project area, showing boundaries and identifying labels of Wetland Assessment Areas and project features.

Other pertinent documentation (describe):

Field Data Forms and assessment summaries (listed in table below):

\begin{tabular}{|c|c|c|c|c|c|c|c|}
\hline \multirow{3}{*}{$\begin{array}{c}\text { Wetland } \\
\text { Assessment } \\
\text { Area } \\
\text { (WAA) ID } \\
\text { Number }\end{array}$} & \multirow{3}{*}{$\begin{array}{c}\text { HGM } \\
\text { Subclass }\end{array}$} & \multirow{3}{*}{$\begin{array}{c}\text { WAA Size } \\
\text { (ha) }\end{array}$} & \multirow{3}{*}{$\begin{array}{l}\text { Number } \\
\text { of plots } \\
\text { sampled }\end{array}$} & \multicolumn{4}{|c|}{ Attached Data Forms and Summary Forms } \\
\hline & & & & \multicolumn{3}{|c|}{$\begin{array}{c}\text { Data Forms } \\
\text { (number attached) }\end{array}$} & \multirow[b]{2}{*}{$\begin{array}{c}\text { FCI/FCU } \\
\text { Calculator } \\
\text { Output } \\
\text { (from } \\
\text { spreadsheet) }\end{array}$} \\
\hline & & & & $\begin{array}{l}\text { WAA or } \\
\text { Tract } \\
\text { Data } \\
\text { (1 per } \\
\text { WAA) }\end{array}$ & $\begin{array}{c}\text { Plot } \\
\text { Data } \\
\text { (sets } \\
\text { of } 2 \\
\text { sheets } \\
\text { per } \\
\text { plot) }\end{array}$ & $\begin{array}{l}\text { WAA Plot } \\
\text { Data } \\
\text { Summary } \\
\text { (from } \\
\text { spreadsheet) }\end{array}$ & \\
\hline & & & & & & & \\
\hline & & & & & & & \\
\hline & & & & & & & \\
\hline & & & & & & & \\
\hline & & & & & & & \\
\hline & & & & & & & \\
\hline & & & & & & & \\
\hline
\end{tabular}




\section{APPENDIX A2}

\section{FIELD ASSESSMENT PREPARATION CHECKLIST}

Prior to conducting field studies, review the checklist below to determine what field gear will be required, and how many copies of each data form will be needed. It may be helpful to complete as much of the Project or Site Description Form (Appendix A1) as possible prior to going to the field, and for large or complex assessment areas, that form should be completed as part of a reconnaissance study to classify and map all of the Wetland Assessment Areas within the project area or site boundary.

\begin{tabular}{|c|c|}
\hline $\begin{array}{l}\text { FIELD GEAR } \\
\text { REQUIRED }\end{array}$ & COMMENTS \\
\hline $\begin{array}{l}\text { DISTANCE TAPE } \\
\text { (preferably metric, at least } \\
50 \mathrm{ft} \text { or } 20 \mathrm{~m} \text { ) AND } \\
\text { ANCHOR PIN }\end{array}$ & $\begin{array}{l}\text { Minimum of } 1 \text {, but } 2 \text { will speed work if enough people are available to } \\
\text { independently record different information. } \\
\text { A survey pin is handy to mark the plot center and anchor the tape for } \\
\text { woody debris transects and for determining plot boundaries. }\end{array}$ \\
\hline FOLDING RULE & $\begin{array}{l}\text { A folding rule, small tape, or dbh caliper suitable for measuring the } \\
\text { diameter of logs is needed. }\end{array}$ \\
\hline $\begin{array}{l}\text { PLANT } \\
\text { IDENTIFICATION } \\
\text { MANUALS }\end{array}$ & $\begin{array}{l}\text { At least one person on the assessment team must be able to readily and } \\
\text { reliably identify woody species, but field guides are recommended as part } \\
\text { of the assessment tool kit. If species of concern, threatened, or endangered } \\
\text { species are potentially present, the assessment team should include a } \\
\text { botanist who can recognize them. }\end{array}$ \\
\hline $\begin{array}{l}\text { PLOT LAYOUT } \\
\text { DIAGRAM }\end{array}$ & A copy is attached to this checklist. \\
\hline DATA FORMS & See data form requirements table, below. \\
\hline $\begin{array}{l}\text { BASAL AREA PRISM } \\
\text { OR DBH TAPE OR } \\
\text { SUITABLE } \\
\text { SUBSTITUTE }\end{array}$ & $\begin{array}{l}\text { A 10-factor non-SI unit wedge prism (available from forestry equipment } \\
\text { supply companies) is the recommended tool for quickly determining tree } \\
\text { basal area. Other tools may be substituted if they provide comparable data. } \\
\text { Guidelines for the use of the wedge prism are attached to this checklist. If } \\
\text { using a dbh tape or caliper, note that you will need the supplemental field } \\
\text { data form for recording diameter measurements (Data Form C1). }\end{array}$ \\
\hline SOIL SURVEY & Optional, but may be helpful in evaluating soil-related variables. \\
\hline $\begin{array}{l}\text { HGM GUIDEBOOK (this } \\
\text { document) }\end{array}$ & $\begin{array}{l}\text { All assessment team members should be familiar with the entire document } \\
\text { prior to fieldwork. }\end{array}$ \\
\hline $\begin{array}{l}\text { SHOVEL OR HEAVY- } \\
\text { DUTY TROWEL }\end{array}$ & $\begin{array}{l}\text { If heavy or hard soils are anticipated, a shovel will be necessary. You need } \\
\text { to be able to dig at least } 10 \mathrm{in} \text {. deep. A water bottle is recommended if } \\
\text { conditions are dry, to help distinguish soil colors (organic-stained soils } \\
\text { must be distinguished from mineral soil). }\end{array}$ \\
\hline $\begin{array}{l}\text { MISCELLANEOUS } \\
\text { SUGGESTED GEAR }\end{array}$ & $\begin{array}{l}\text { You'll need clipboards and pencils, and extra data forms are highly } \\
\text { recommended. Flagging may be helpful for establishing plot centers and } \\
\text { boundaries, at least until the assessment team is comfortable with the field } \\
\text { procedures. A camera and GPS unit will improve documentation of the } \\
\text { assessment and are highly recommended. Record position and take a } \\
\text { representative photo at each plot location. Field copies of aerial photos and } \\
\text { topographic maps may be important if multiple Wetland Assessment Areas } \\
\text { must be established and recognized in the field. }\end{array}$ \\
\hline
\end{tabular}




\section{APPENDIX A2}

\section{DATA FORM REQUIREMENTS}

Print or copy the following data forms (Data Forms 1 and 2 are found in Appendix B) in the numbers indicated. (Extras are always a good idea.) Be sure to use the forms developed specifically for the wetland subclass(es) you are assessing. In order to print forms from the spreadsheet, the appropriate subclass(es) must first be selected from the dropdown list on the spreadsheet.

\begin{tabular}{|c|c|}
\hline DATA FORM & $\begin{array}{c}\text { Number of Copies } \\
\text { Required }\end{array}$ \\
\hline $\begin{array}{l}\text { Project or Site Description and Assessment Documentation } \\
\qquad(1 \text { page })\end{array}$ & 1 \\
\hline $\begin{array}{l}\text { Data Sheet } 1 \text { - Tract and WAA-Level Variables } \\
(1 \text { page }) \\
\text { (Complete using maps, photos, hydrologic data, field reconnaissance, etc.) }\end{array}$ & $\begin{array}{l}1 \text { per Wetland Assessment } \\
\text { Area }\end{array}$ \\
\hline $\begin{array}{c}\text { Data Sheet } 2 \text { - Plot-Level Variables } \\
(2 \text { pages per set) } \\
\text { (Complete by sampling within nested circular plots and along transects) }\end{array}$ & $\begin{array}{l}\text { Multiple sets, depending } \\
\text { on size, variability, and } \\
\text { number of Wetland } \\
\text { Assessment Areas (see } \\
\text { Chapter 6) }\end{array}$ \\
\hline
\end{tabular}




\section{APPENDIX A3}

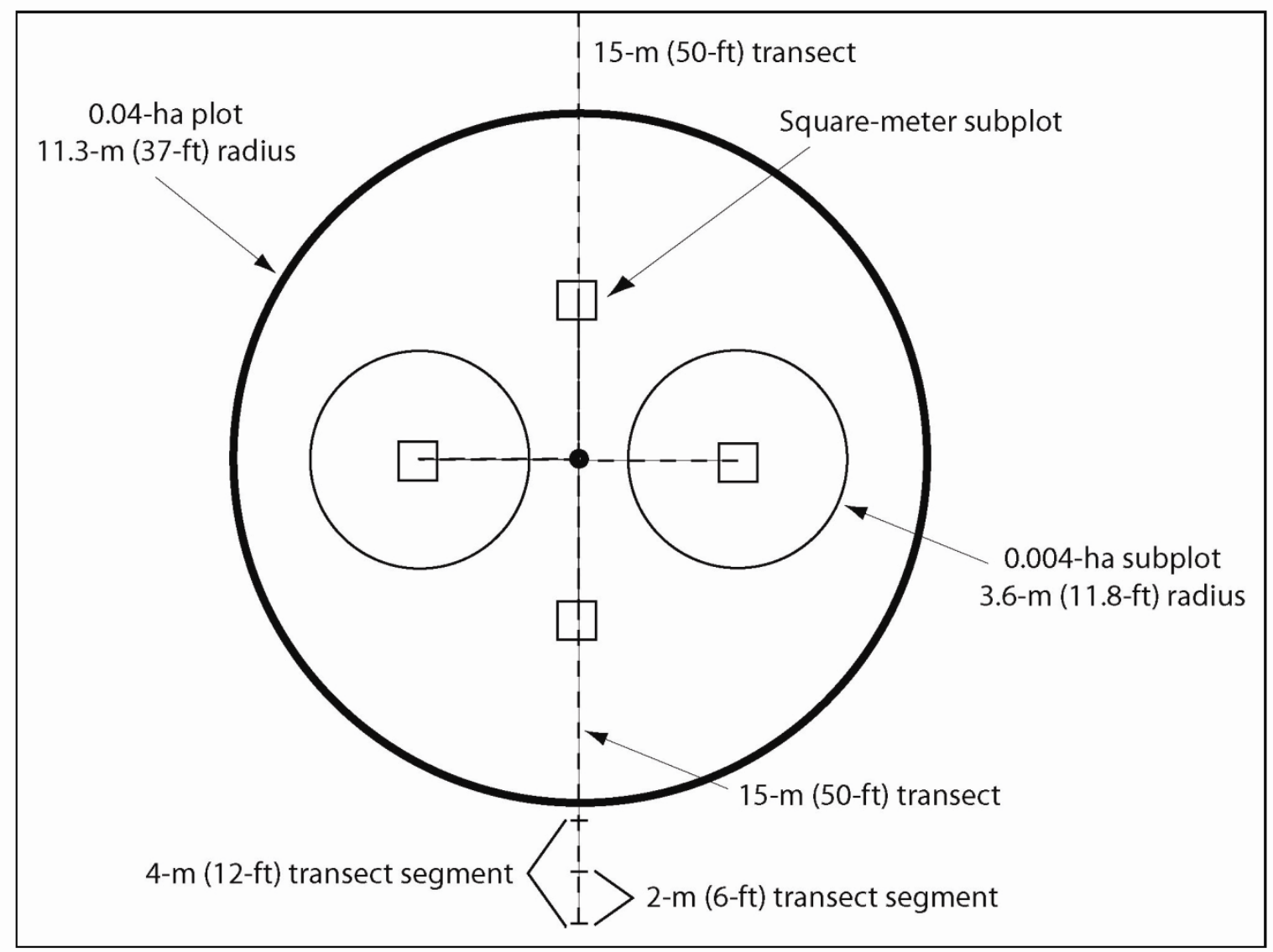

Figure A 1. Layout of plots and transects for field sampling. 


\section{Appendix B: Field Data Forms}

\section{Contents}

Appendix B1. Low-Gradient Riverine Wetlands

Appendix B2. Mid-Gradient Riverine Wetlands

Appendix B3. Connected Depression Wetlands 


\section{Appendix B1}

\section{Field Data Forms for Low-Gradient Riverine Wetlands}

\begin{tabular}{|l|l|l|}
\hline Data Form & Number of Pages & Title \\
\hline 1 & 1 & Tract and Wetland Assessment Area Level Data Collection \\
\hline 2 & 2 & Plot-Level Data Collection \\
\hline \multicolumn{2}{|l}{ Please reproduce forms for local use as needed. } \\
\hline
\end{tabular}




\begin{tabular}{|lcl}
\hline Appendix B1-1 & Data Sheet 1 \\
WAA/Tract Data
\end{tabular}

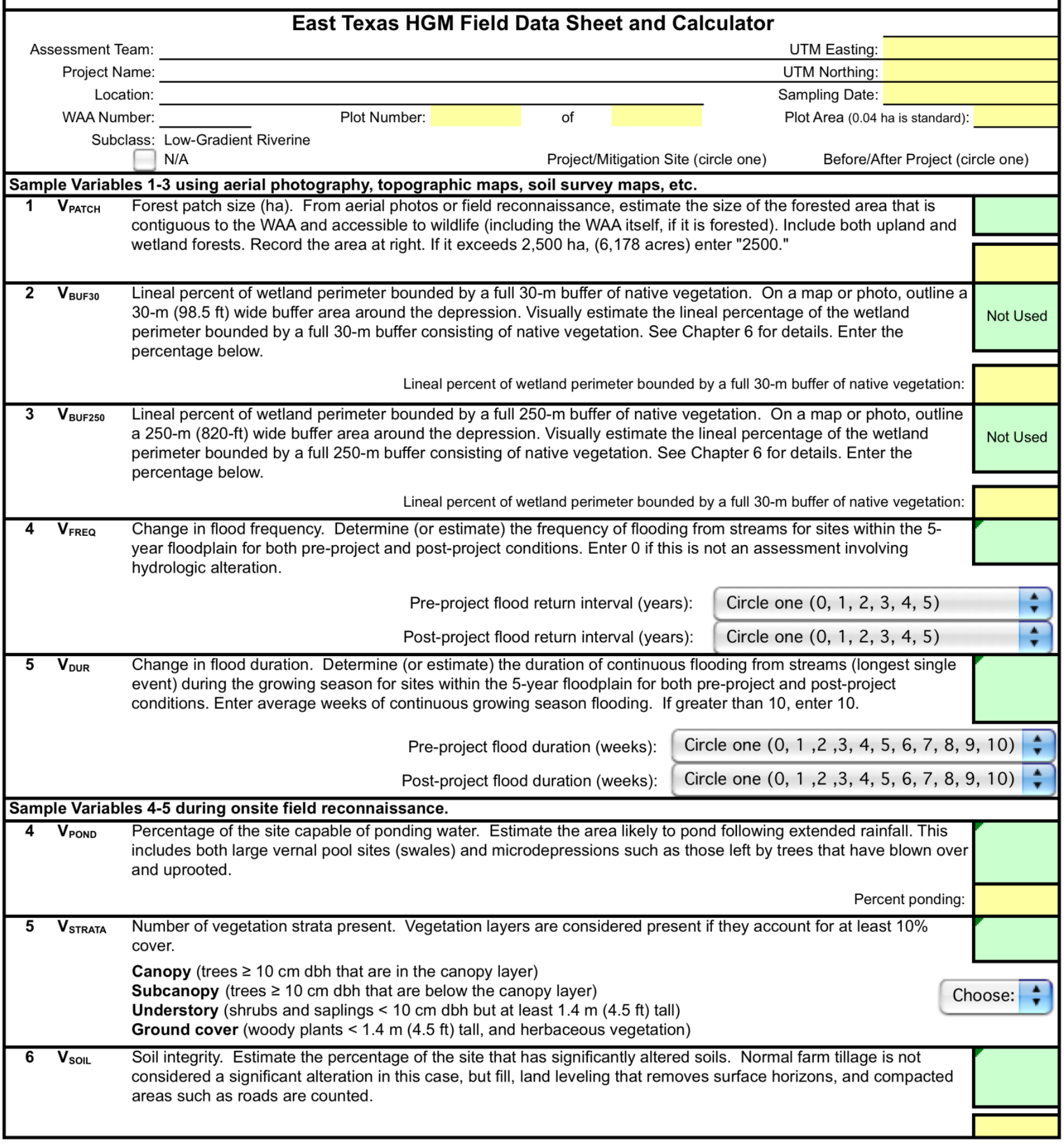




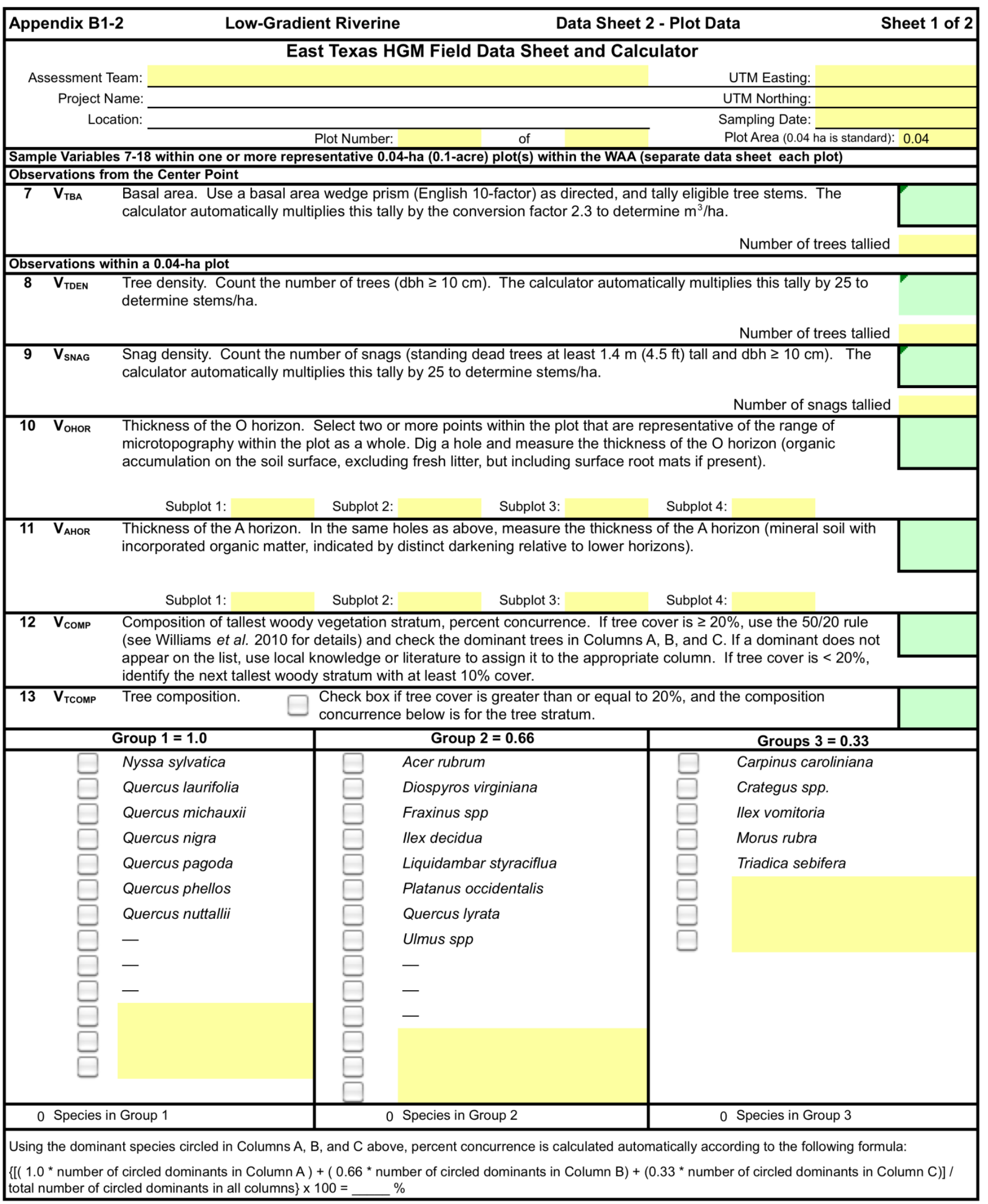




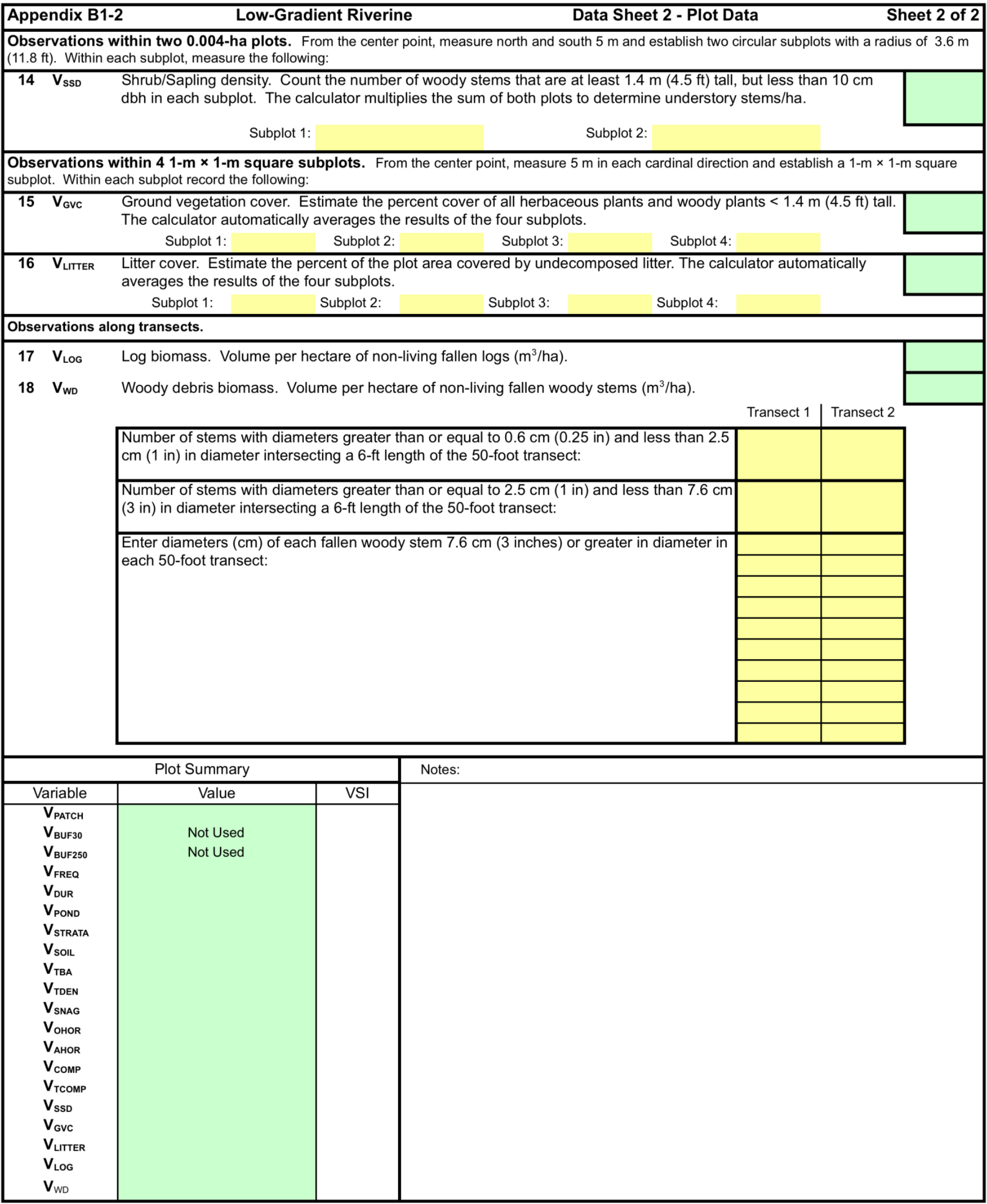




\section{Appendix B2}

\section{Field Data Forms for Mid-Gradient Riverine Wetlands}

\begin{tabular}{|l|l|l|}
\hline Data Form & Number of Pages & Title \\
\hline 1 & 1 & Tract and Wetland Assessment Area Level Data Collection \\
\hline 2 & 2 & Plot-Level Data Collection \\
\hline \multicolumn{2}{|l}{ Please reproduce forms for local use as needed. } \\
\hline
\end{tabular}




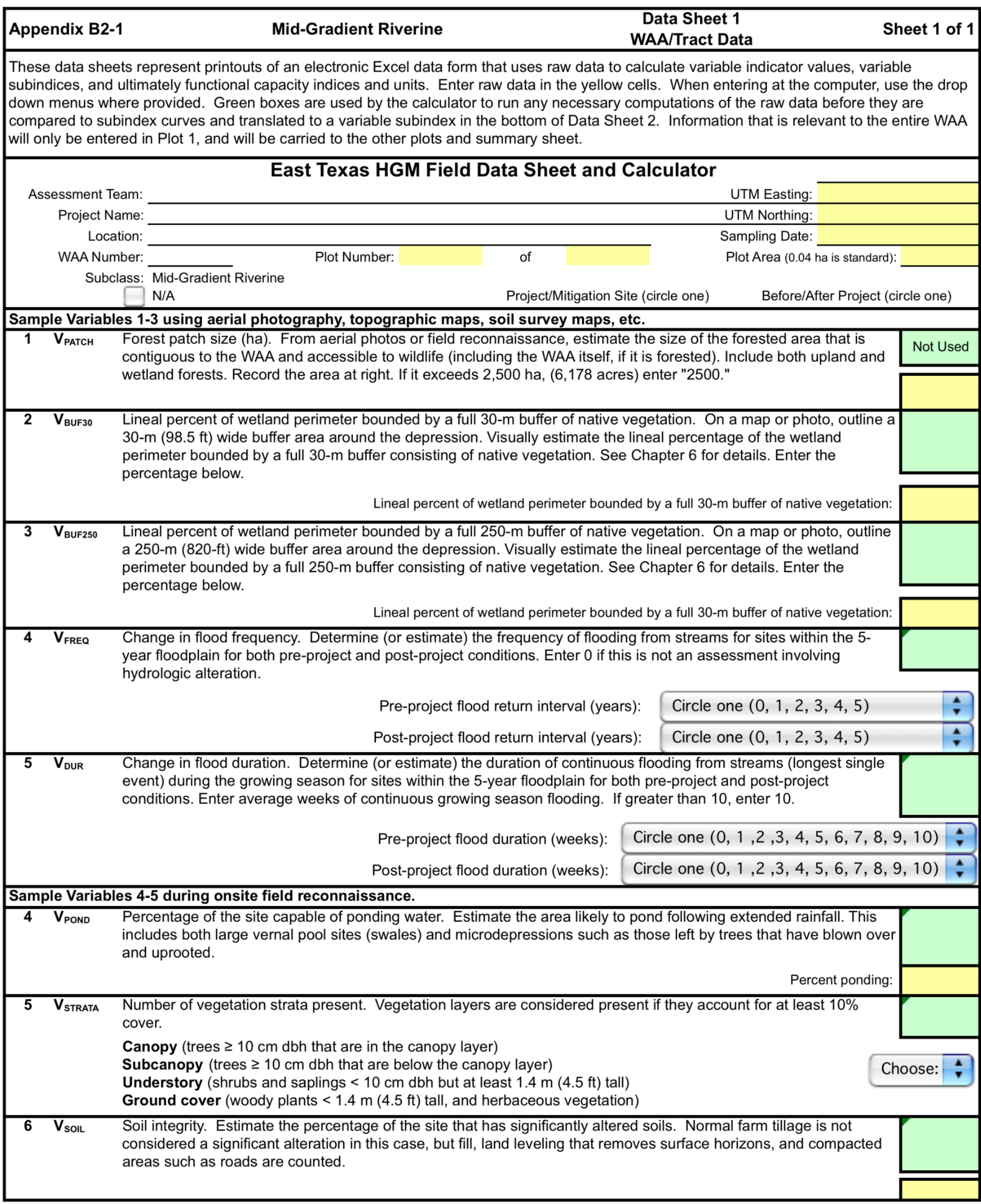




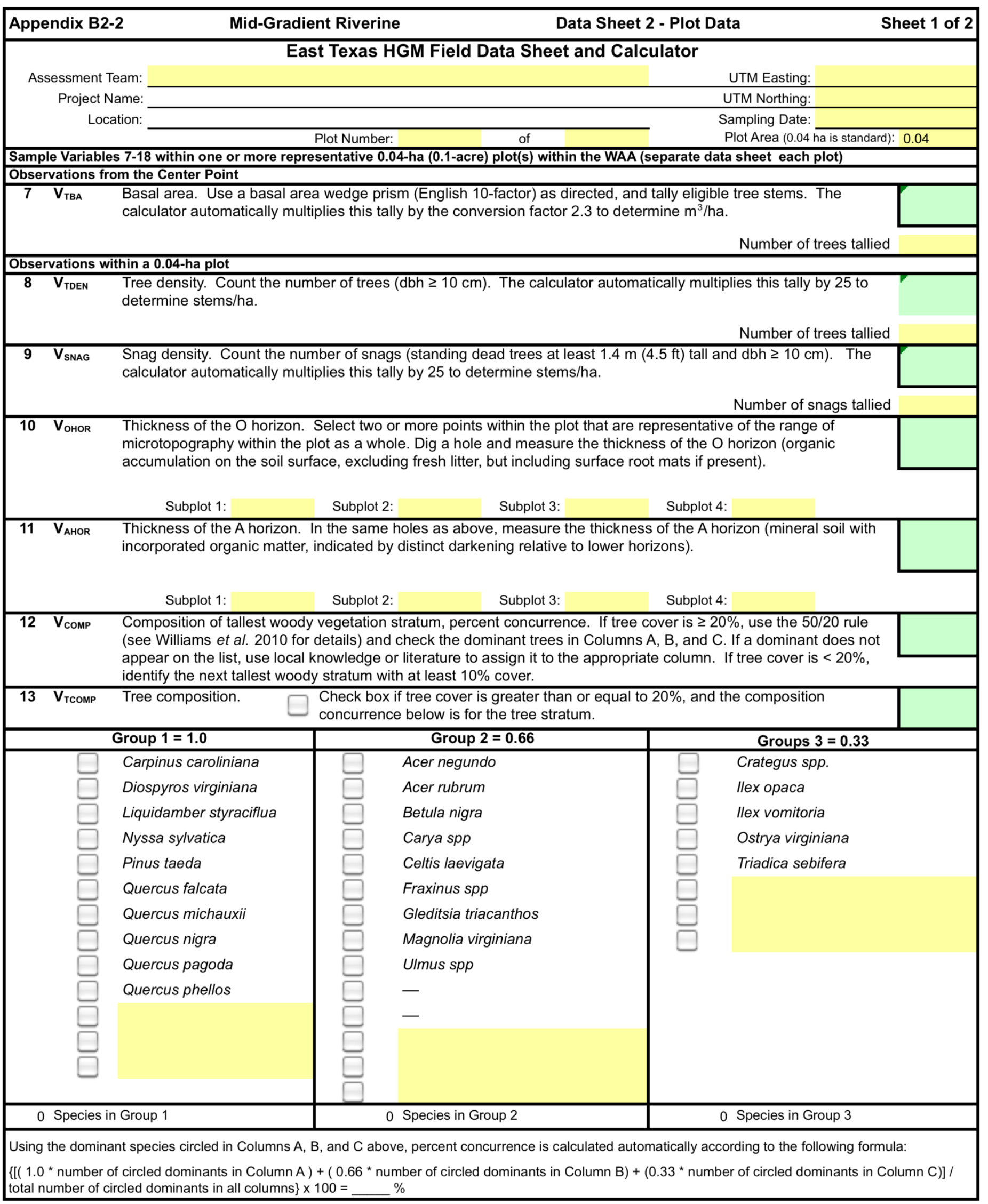




\section{Appendix B2-2}

Mid-Gradient Riverine

Data Sheet 2 - Plot Data

Sheet 2 of 2

Observations within two 0.004-ha plots. From the center point, measure north and south $5 \mathrm{~m}$ and establish two circular subplots with a radius of $3.6 \mathrm{~m}$ $(11.8 \mathrm{ft})$. Within each subplot, measure the following:

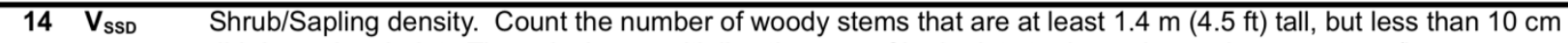
$\mathrm{dbh}$ in each subplot. The calculator multiplies the sum of both plots to determine understory stems/ha.

Subplot 1:

Subplot 2:

Observations within $41-\mathrm{m} \times 1-\mathrm{m}$ square subplots. From the center point, measure $5 \mathrm{~m}$ in each cardinal direction and establish a 1-m $\times 1$-m square subplot. Within each subplot record the following:

$15 \mathbf{V}_{\mathrm{Gvc}} \quad$ Ground vegetation cover. Estimate the percent cover of all herbaceous plants and woody plants $<1.4 \mathrm{~m}(4.5 \mathrm{ft})$ tall. The calculator automatically averages the results of the four subplots.
Subplot 1:
Subplot 2:
Subplot 3:
Subplot 4:

$16 V_{\text {LITTER }}$ Litter cover. Estimate the percent of the plot area covered by undecomposed litter. The calculator automatically averages the results of the four subplots.
Subplot 1 :
Subplot 2
Subplot 3:
Subplot 4

Observations along transects.

$17 V_{\text {LOG }}$ Log biomass. Volume per hectare of non-living fallen logs $\left(\mathrm{m}^{3} / \mathrm{ha}\right)$.

$18 \mathrm{~V}_{\mathrm{WD}} \quad$ Woody debris biomass. Volume per hectare of non-living fallen woody stems $\left(\mathrm{m}^{3} / \mathrm{ha}\right)$.

\begin{tabular}{l|l} 
Transect 1 & Transect 2
\end{tabular}

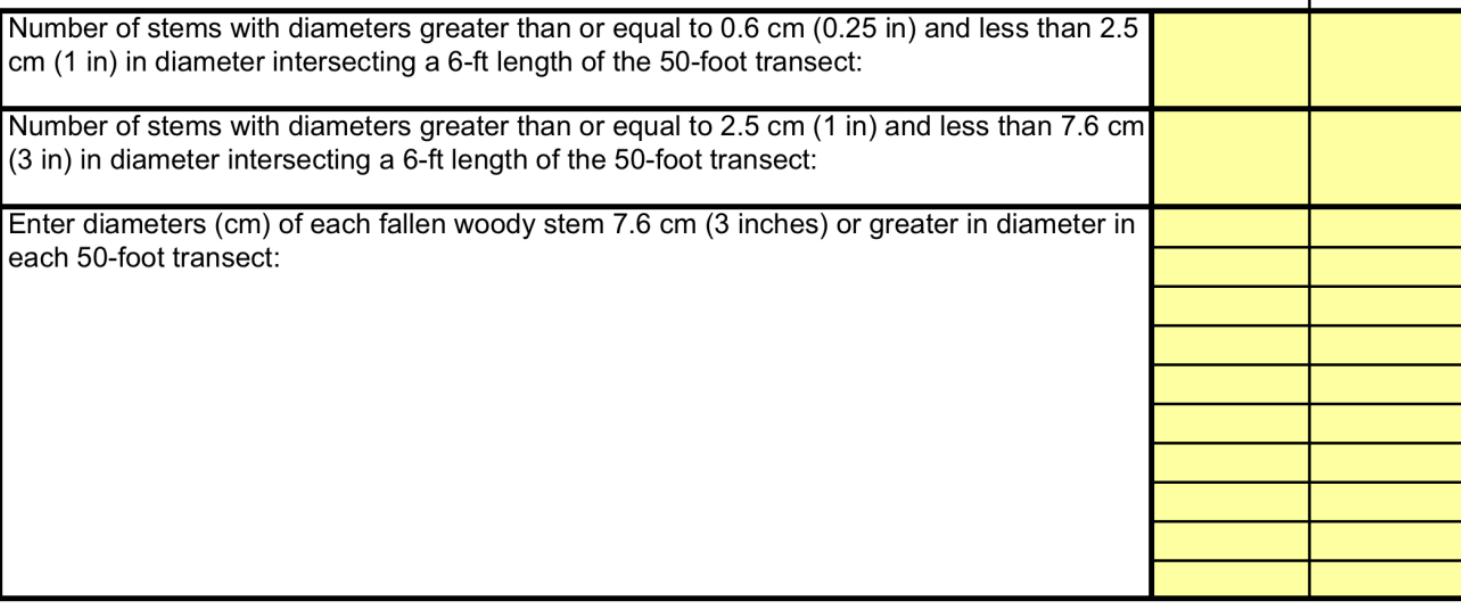

\begin{tabular}{|l|c|c|l|}
\hline \multicolumn{2}{|c|}{ Plot Summary } & Notes: \\
\hline Variable & Value & & \\
\hline $\mathbf{V}_{\text {PATCH }}$ & Not Used & & \\
$\mathbf{V}_{\text {BUF30 }}$ & & & \\
$\mathbf{V}_{\text {BUF250 }}$ & & & \\
$\mathbf{V}_{\text {FREQ }}$ & & & \\
$\mathbf{V}_{\text {DUR }}$ & & & \\
$\mathbf{V}_{\text {POND }}$ & & \\
$\mathbf{V}_{\text {STRATA }}$ & & \\
$\mathbf{V}_{\text {SOIL }}$ & & \\
$\mathbf{V}_{\text {TBA }}$ & & & \\
$\mathbf{V}_{\text {TDEN }}$ & & & \\
$\mathbf{V}_{\text {SNAG }}$ & & & \\
$\mathbf{V}_{\text {OHOR }}$ & & & \\
$\mathbf{V}_{\text {AHOR }}$ & & & \\
$\mathbf{V}_{\text {COMP }}$ & & & \\
$\mathbf{V}_{\text {TCOMP }}$ & & & \\
$\mathbf{V}_{\text {SSD }}$ & & & \\
$\mathbf{V}_{\text {GVC }}$ & & & \\
$\mathbf{V}_{\text {LITTR }}$ & & & \\
$\mathbf{V}_{\text {LOG }}$ & & & \\
$\mathbf{V}_{\text {WD }}$ & & & \\
\hline
\end{tabular}




\section{Appendix B3}

Field Data Forms for Connected Depression Wetlands

\begin{tabular}{|l|l|l|}
\hline Data Sheet & Number of Pages & Title \\
\hline 1 & 1 & Tract and Wetland Assessment Area Level Data Collection \\
\hline 2 & 2 & Plot-Level Data Collection \\
\hline \multicolumn{2}{|l}{ Please reproduce forms for local use as needed. } \\
\hline
\end{tabular}




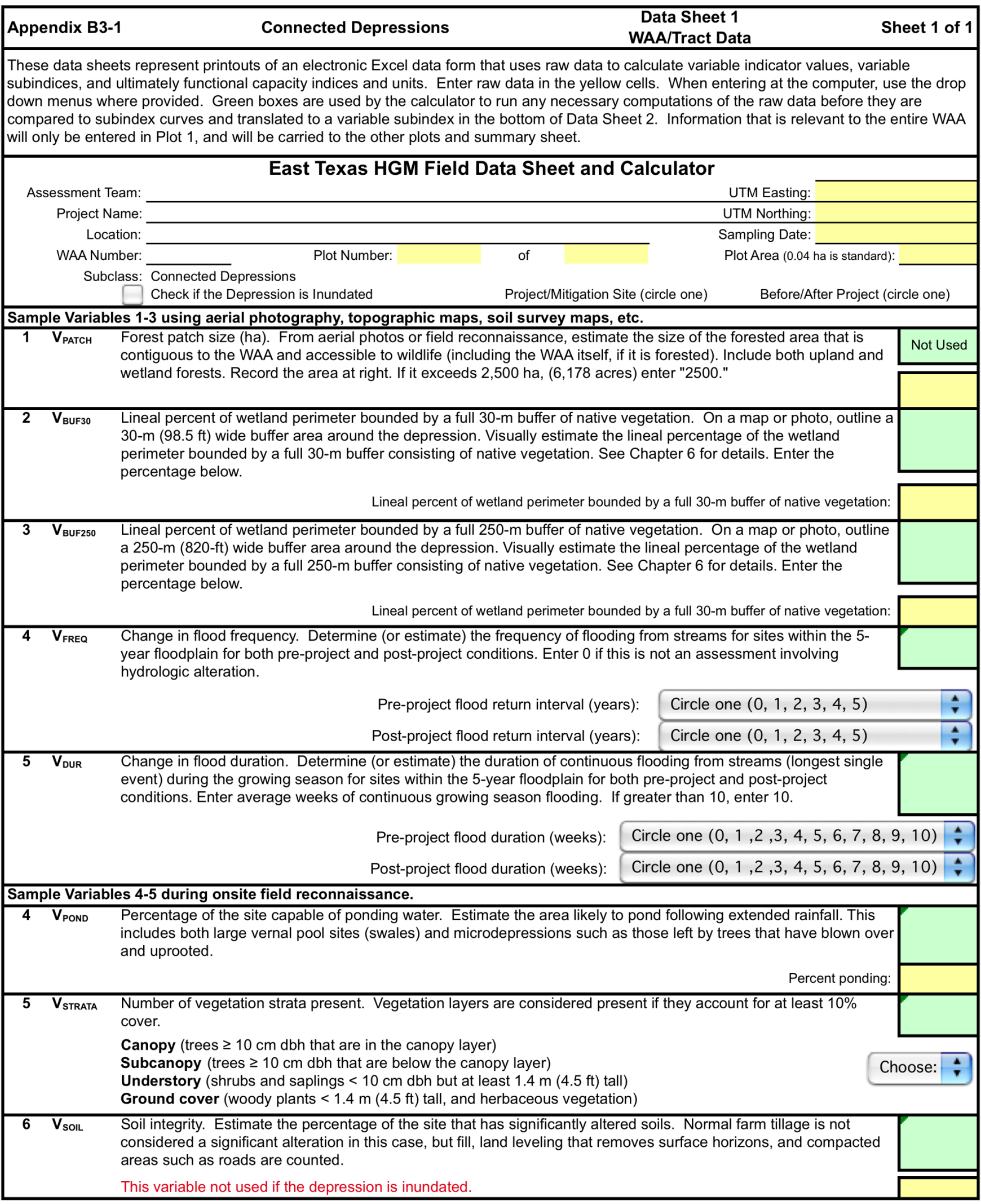




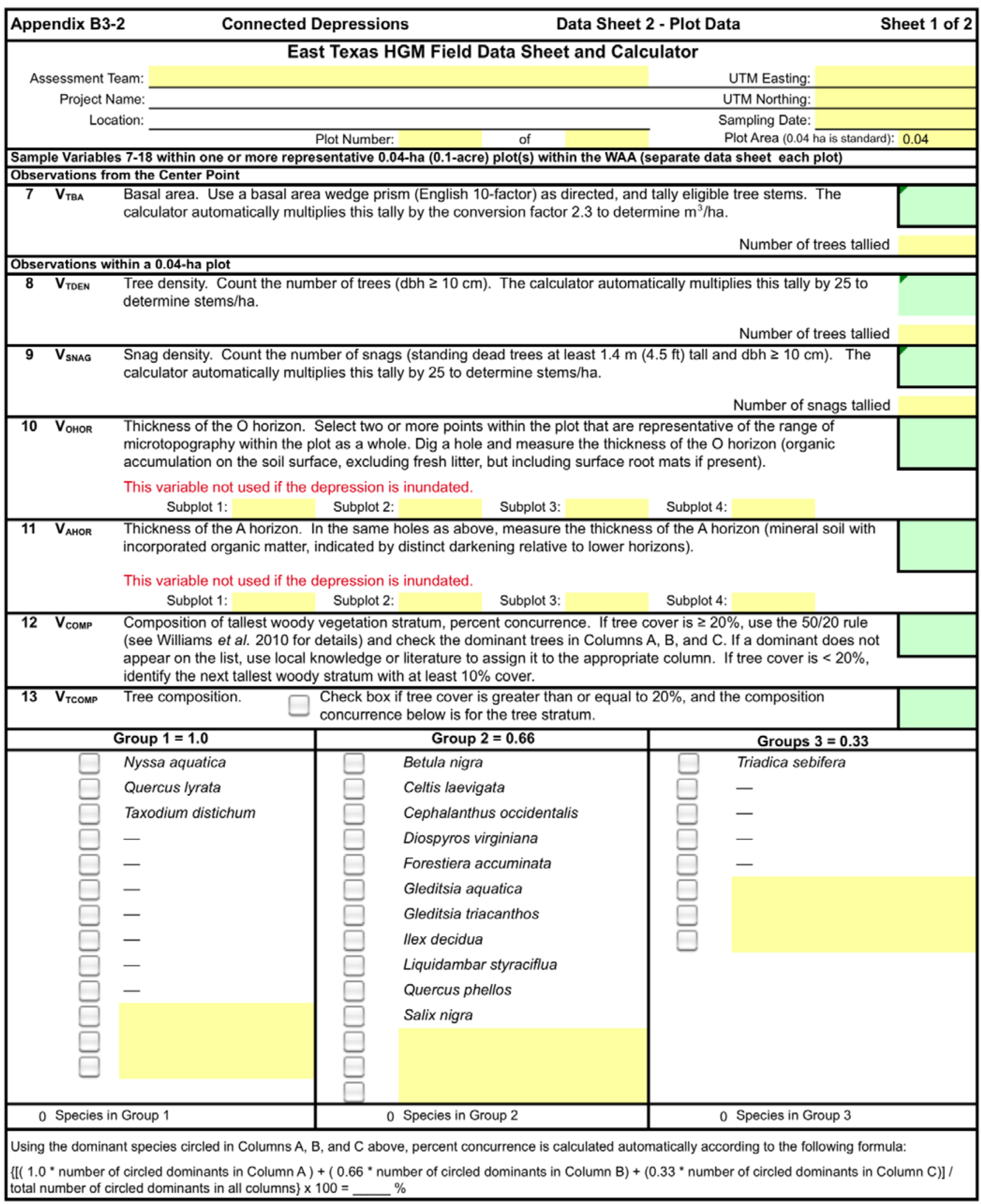




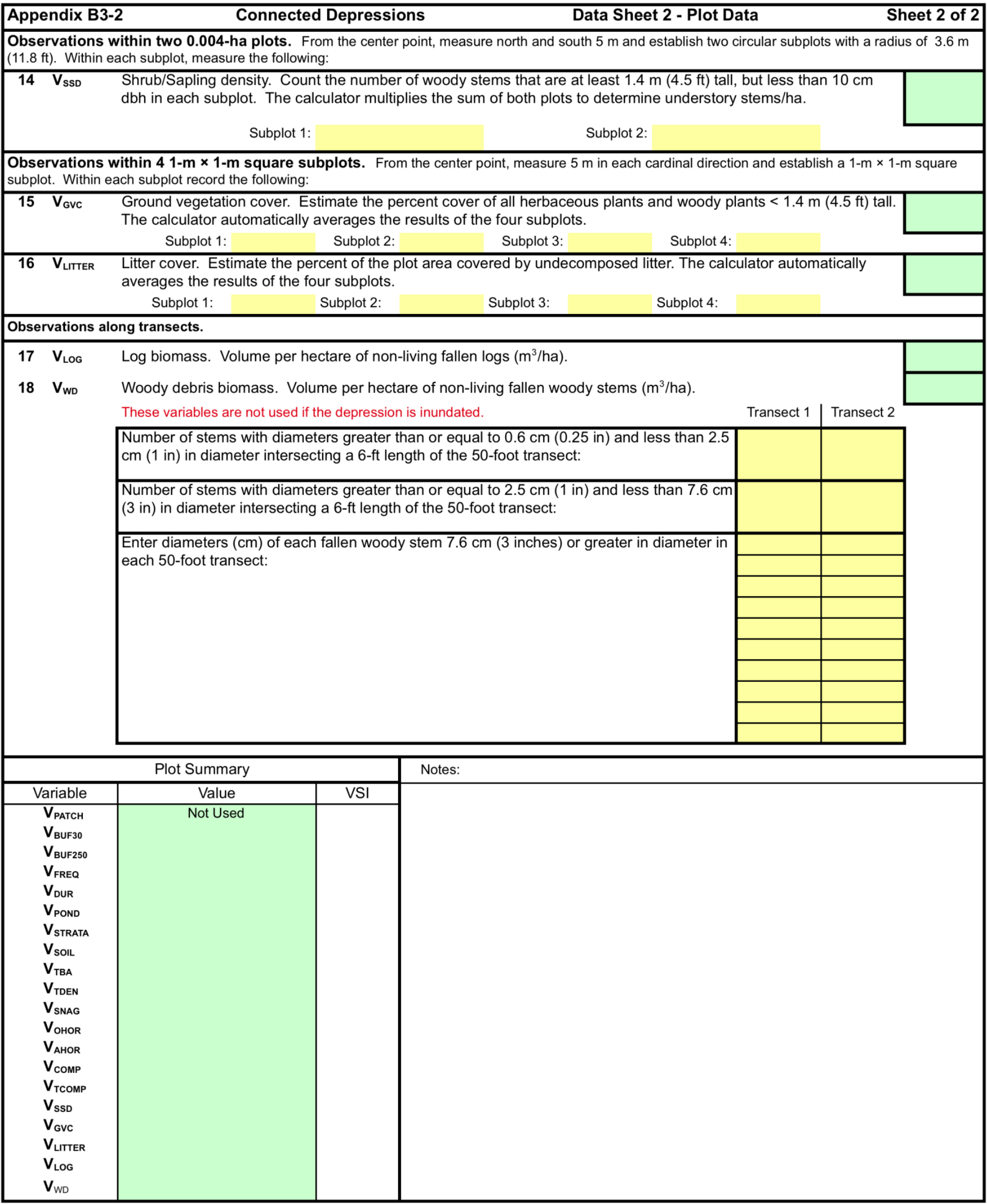




\section{Appendix C: Example Spreadsheet Output Forms}

Appendix C1. Example WAA plot data summary output

Appendix C2. Example FCI/ FCU calculator spreadsheet summary output 


\begin{tabular}{|c|c|c|c|c|c|c|c|c|c|c|c|c|}
\hline \multicolumn{2}{|c|}{ WAA Data Summary: } & \multicolumn{7}{|c|}{ WAA Number : } & \multicolumn{4}{|c|}{ Low-Gradient Riverine } \\
\hline Variable & Plot 1 & Plot 2 & Plot 3 & Plot 4 & Plot 5 & Plot 6 & Plot 7 & Plot 8 & Plot 9 & Plot 10 & $\begin{array}{c}\text { Number of } \\
\text { Plots } \\
\text { Used }\end{array}$ & $\begin{array}{l}\text { Average } \\
\text { Measure }\end{array}$ \\
\hline \multicolumn{13}{|l|}{$\mathbf{V}_{\text {PATCH }}$} \\
\hline $\mathrm{V}_{\text {BUF } 30}$ & Not Used & Not Used & $\begin{array}{l}\text { Not Used } \\
\end{array}$ & Not Used & Not Used & Not Used & Not Used & Not Used & Not Used & \begin{tabular}{|l} 
Not Used \\
\end{tabular} & Not Used & Not Used \\
\hline $\mathrm{V}_{\text {BUF250 }}$ & \begin{tabular}{|l} 
Not Used \\
\end{tabular} & Not Used & \begin{tabular}{|l|} 
Not Used \\
\end{tabular} & Not Used & Not Used & \begin{tabular}{|l} 
Not Used \\
\end{tabular} & Not Used & Not Used & Not Used & \begin{tabular}{|l|} 
Not Used \\
\end{tabular} & Not Used & Not Used \\
\hline \multicolumn{13}{|c|}{ 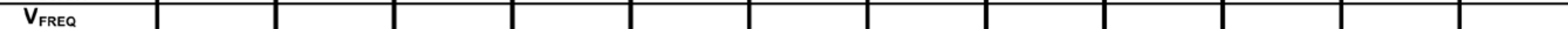 } \\
\hline \multicolumn{13}{|l|}{$V_{\text {DUR }}$} \\
\hline \multirow{2}{*}{\multicolumn{13}{|c|}{$V_{\text {POND }}$}} \\
\hline \multirow{2}{*}{\multicolumn{13}{|c|}{$\begin{array}{l}V_{\text {STRATA }} \\
V_{\text {SOIL }}\end{array}$}} \\
\hline & & & & & & & & & & & & \\
\hline \multicolumn{13}{|l|}{$V_{\text {TBA }}$} \\
\hline \multirow{2}{*}{\multicolumn{13}{|c|}{$\begin{array}{l}\mathbf{V}_{\text {TDEN }} \\
\mathbf{V}_{\text {SNAG }}\end{array}$}} \\
\hline & & & & & & & & & & & & \\
\hline \multicolumn{13}{|l|}{$V_{\text {OHOR }}$} \\
\hline \multirow{2}{*}{\multicolumn{13}{|c|}{$\frac{\mathbf{V}_{\text {AHOR }}}{\mathbf{V}_{\text {COMP }}}$}} \\
\hline & & & & & & & & & & & & \\
\hline \multicolumn{13}{|l|}{$V_{\text {TCOMP }}$} \\
\hline \multicolumn{13}{|l|}{$V_{\text {SSD }}$} \\
\hline \multirow{2}{*}{\multicolumn{13}{|c|}{$\mathrm{V}_{\mathrm{GVC}}$}} \\
\hline \multirow{2}{*}{\multicolumn{13}{|c|}{$\begin{array}{l}V_{\text {LITTER }} \\
V_{\text {IOG }}\end{array}$}} \\
\hline & & & & & & & & & & & & \\
\hline$V_{\text {wD }}$ & & & & & & & & & & & & \\
\hline
\end{tabular}




\section{FCI/FCU Calculator for the East Texas HGM Guidebook}

To create appropriate plot data entry forms and ensure accurate calculations, select the HGM Subclass present on the site in the drop list below. Enter in the yellow cells the number and size of the Wetland Assessment Area (WAA) being sampled, the project name, and location. Use the drop down menus to indicate whether this WAA represents the Project Site or Mitigation Site, before project or after project. Then go to the Data Entry tabs to enter individual field measurements for each plot. Information that is relevant to the entire WAA will only be entered in Plot 1, and will be carried to the other plots and summary sheet. For information on determining how to split a project into WAAs, see A Regional Guidebook for Applying the Hydrogeomorphic Approach to the Functional Assessment of Forested Wetlands in Alluvial Valleys of East Texas (Williams et al. 2010)

Project Name:

Location:

Sampling Dates: Enter dates on Plot Sheets

Select HGM Subclass present at this WAA:

WAA number:

WAA size (ha):

Functional Results Summary:

\begin{tabular}{|l|l|l|}
\hline \multicolumn{1}{|c|}{ Function } & $\begin{array}{c}\text { Functional } \\
\text { Capacity Index }\end{array}$ & $\begin{array}{c}\text { Functional } \\
\text { Capacity Units }\end{array}$ \\
\hline Detain Floodwater & & \\
\hline Detain Precipitation & & \\
\hline Cycle Nutrients & & \\
\hline Export Organic Carbon & & \\
\hline Maintain Plant Communities & & \\
\hline Provide Habitat for Fish and Wildlife & & \\
\hline
\end{tabular}

Variable Measure and Subindex Summary:

\begin{tabular}{|c|c|c|c|}
\hline Variable & Name & $\begin{array}{l}\text { Average } \\
\text { Measure }\end{array}$ & Subindex \\
\hline $\mathbf{V}_{\text {PATCH }}$ & Forested Patch Size (ha) & & \\
\hline $\mathbf{V}_{\text {BUF30 }}$ & Percent of Perimeter Bounded by $30-\mathrm{m}$ Buffer (\%) & & \\
\hline $\mathrm{V}_{\text {BUF250 }}$ & Percent of Perimeter Bounded by $250-\mathrm{m}$ Buffer (\%) & & \\
\hline $\mathbf{V}_{\text {FREO }}$ & Change in Frequency of Flooding (years change) & & \\
\hline $\mathbf{V}_{\text {DUR }}$ & Change in Growing Season Flood Duration (weeks change) & & \\
\hline$V_{\text {POND }}$ & Total Ponded Area (\%) & & \\
\hline$V_{\text {STRATA }}$ & Number of Vegetation Strata & & \\
\hline $\mathbf{V}_{\text {soll }}$ & Soil Integrity $(\%)$ & & \\
\hline $\mathbf{V}_{\text {TBA }}$ & Tree Basal Area $\left(\mathrm{m}^{3} / \mathrm{ha}\right)$ & & \\
\hline $\mathbf{V}_{\text {TDEN }}$ & Tree Density (stems/ha) & & \\
\hline $\mathbf{V}_{\text {SNAG }}$ & Snag Density (stems/ha) & & \\
\hline $\mathbf{V}_{\text {OHOR }}$ & O Horizon Organic Accumulation $(\mathrm{cm})$ & & \\
\hline $\mathbf{V}_{\text {AHOR }}$ & A Horizon Organic Accumulation $(\mathrm{cm})$ & & \\
\hline $\mathbf{V}_{\text {COMP }}$ & Composition of Tallest Woody Vegetation Stratum (\%) & & \\
\hline $\mathbf{V}_{\text {TсомP }}$ & Tree Composition (\%) & & \\
\hline $\mathbf{V}_{\text {SSD }}$ & Shrub-Sapling Density (stems/ha) & & \\
\hline $\mathbf{V}_{\mathrm{GVC}}$ & Ground Vegetation Cover (\%) & & \\
\hline V LITTER $_{2}$ & Litter Cover (\%) & & \\
\hline $\mathbf{V}_{\text {LOG }}$ & Log Biomass $\left(\mathrm{m}^{3} / \mathrm{ha}\right)$ & & \\
\hline$V_{\text {wD }}$ & Woody Debris Biomass (m/ha) & & \\
\hline
\end{tabular}




\section{Appendix D: Common and Scientific Names of Plant Species Referenced in Text and Data Forms}

\begin{tabular}{|c|c|}
\hline Common Name & Scientific Name \\
\hline Acer negundo & box elder \\
\hline Acer rubrum & red maple \\
\hline Arundinaria gigantean & switchcane \\
\hline Berchemia scandens & supplejack \\
\hline Betula nigra & river birch \\
\hline Campsis radicans & trumpet creeper \\
\hline Carpinus caroliniana & ironwood \\
\hline Carya aquatica & water hickory \\
\hline Carya illinoensis & pecan \\
\hline Carya spp. & hickory \\
\hline Celtis laevigata & sugarberry \\
\hline Celtis occidentalis & hackberry \\
\hline Cephalanthus occidentalis & buttonbush \\
\hline Chasmanthium latifolium & wild oat \\
\hline Cornus racemosa & red-panicle dogwood \\
\hline Crataegus opaca & apple haw \\
\hline Crataegus spp. & hawthorn \\
\hline Diospyros virginiana & persimmon \\
\hline Drosera spp. & sundew \\
\hline Forestiera acuminata & swamp privet \\
\hline Fraxinus caroliniana & Carolina ash \\
\hline Fraxinus pennsylvanica & green ash \\
\hline Fraxinus spp. & ash \\
\hline Gelsemium sp. & jessamine \\
\hline Gleditsia aquatica & water locust \\
\hline Gleditsia triacanthos & honey locust \\
\hline Halesia diptera & two-winged silverbell \\
\hline
\end{tabular}




\begin{tabular}{|c|c|}
\hline Common Name & Scientific Name \\
\hline Hypericum hypericoides & St. Andrew's-cross \\
\hline Ilex decidua & deciduous holly \\
\hline Ilex ораса & American holly \\
\hline Ilex vomitoria & yaupon \\
\hline Itea virginica & Virginia willow \\
\hline Ligustrum sinense & Chinese privet \\
\hline Liquidambar styraciflua & sweetgum \\
\hline Lonicera japonica & Japanese honeysuckle \\
\hline Magnolia grandiflora & southern magnolia \\
\hline Magnolia virginiana & sweetbay magnolia \\
\hline Morus rubra & red mulberry \\
\hline Myrica cerifera & waxmyrtle \\
\hline Nyssa aquatica & water tupelo \\
\hline Nyssa sylvatica & blackgum \\
\hline Ostrya virginiana & Eastern hophornbeam \\
\hline Pinus taeda & loblolly pine \\
\hline Planera aquatica & water elm \\
\hline Platanus occidentalis & sycamore \\
\hline Polygonum spp. & smartweed \\
\hline Populus deltoides & eastern cottonwood \\
\hline Quercus falcata & southern red oak \\
\hline Quercus laurifolia & laurel oak \\
\hline Quercus lyrata & overcup oak \\
\hline Quercus michauxii & cow oak \\
\hline Quercus nigra & water oak \\
\hline Quercus nuttallii & Nuttall oak \\
\hline Quercus pagoda & cherrybark oak \\
\hline Quercus phellos & willow oak \\
\hline Quercus shumardii & Shumard oak \\
\hline Quercus stellata & post oak \\
\hline Rhynchospora spp. & beakrush \\
\hline Rubus spp. & blackberry \\
\hline Salix nigra & black willow \\
\hline Sarracenia spp. & pitcher plant \\
\hline
\end{tabular}




\begin{tabular}{|l|l|}
\hline Common Name & Scientific Name \\
\hline Saururus cenruus & lizard's tail \\
\hline Smilax sp. & greenbrier \\
\hline Styrax americana & storax \\
\hline Taxodium distichum & baldcypress \\
\hline Toxicodendron radicas & poison ivy \\
\hline Triadica sebifera & Chinese tallowtree \\
\hline Ulmus alata & winged elm \\
\hline Ulmus americana & American elm \\
\hline Ulmus crassifolia & cedar elm \\
\hline Ulmus rubra & slippery elm \\
\hline Ulmus spp. & elm \\
\hline Viburnum nudum & possumhaw \\
\hline Vitis rotundifolia & muscadine grape \\
\hline
\end{tabular}




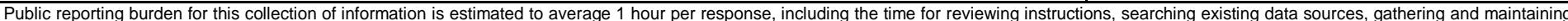

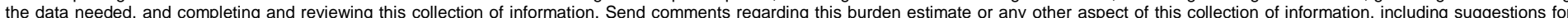

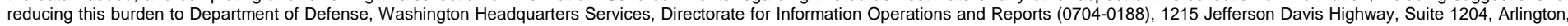

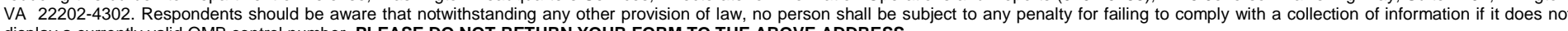
display a currently valid OMB control number. PLEASE DO NOT RETURN YOUR FORM TO THE ABOVE ADDRESS.
1. REPORT DATE (DD-MM-YYYY) 2. REPORT TYPE
October 2010
Final report

\section{TITLE AND SUBTITLE}

A Regional Guidebook for Applying the Hydrogeomorphic Approach to the Functional Assessment of Forested Wetlands in Alluvial Valleys of East Texas

. DATES COVERED (From - To)

5a. CONTRACT NUMBER

5b. GRANT NUMBER

5c. PROGRAM ELEMENT NUMBER

\section{AUTHOR(S)}

5d. PROJECT NUMBER

Hans M. Williams, Adam J. Miller, Rachel S. McNamee, and Charles V. Klimas

5e. TASK NUMBER

\section{5f. WORK UNIT NUMBER}

\section{PERFORMING ORGANIZATION NAME(S) AND ADDRESS(ES)}

8. PERFORMING ORGANIZATION REPORT NUMBER

Arthur Temple College of Forestry and Agriculture

Stephen F. Austin State University

ERDC/EL TR-10-17

419 East College Street

Nacogdoches, TX 75962-6109

9. SPONSORING I MONITORING AGENCY NAME(S) AND ADDRESS(ES)

10. SPONSOR/MONITOR'S ACRONYM(S)

Headquarters, U.S. Army Corps of Engineers

Washington, DC 20314-1000

11. SPONSOR/MONITOR'S REPORT NUMBER(S)

\section{DISTRIBUTION / AVAILABILITY STATEMENT}

Approved for public release; distribution is unlimited.

\section{SUPPLEMENTARY NOTES}

\section{ABSTRACT}

The Hydrogeomorphic (HGM) Approach is a method for developing and applying indices for the site-specific assessment of wetland functions. The HGM Approach was initially designed to be used in the context of the Clean Water Act Section 404 Regulatory Program permit review process to analyze project alternatives, minimize impacts, assess unavoidable impacts, determine mitigation requirements, and monitor the success of compensatory mitigation. However, a variety of other potential uses have been identified, including the design of wetland restoration projects, and management of wetlands.

This Regional Guidebook presents the HGM Approach for assessing the functions of most of the wetlands that occur in alluvial valleys of East Texas. The report begins with an overview of the HGM Approach and then classifies and characterizes the principal wetlands that have been identified within the region. Detailed HGM assessment models and protocols are presented for three of those wetland types, or subclasses: Low-gradient Riverine, Mid-gradient Riverine, and Connected Depression. For each wetland subclass, the guidebook presents (a) the rationale used to select the wetland functions considered in the assessment process, (b) the rationale used to select assessment

(continued)

$\begin{array}{ll}\text { 15. SUBJECT TERMS } & \text { Geomorphology } \\ \text { Clean Water Act } & \text { Hydrology } \\ \text { East Texas } & \text { Impact Assessment } \\ \text { Functional Assessment } & \text { Mitigation }\end{array}$

\section{SECURITY CLASSIFICATION OF:}

\begin{tabular}{|l|l|l|}
\hline a. REPORT & b. ABSTRACT & c. THIS PAGE \\
UNCLASSIFIED & UNCLASSIFIED & UNCLASSIFIED \\
\hline
\end{tabular}

17. LIMITATION
OF ABSTRACT
Wetland
Wetland assessment
Wetland classification
Wetland function
Wetland restoration

\begin{tabular}{c|l|}
\begin{tabular}{c|l} 
18. NUMBER \\
OF PAGES
\end{tabular} & $\begin{array}{l}\text { 19a. NAME OF RESPONSIBLE } \\
\text { PERSON }\end{array}$ \\
\cline { 2 - 2 } 144 & $\begin{array}{l}\text { 19b. TELEPHONE NUMBER (include } \\
\text { area code) }\end{array}$ \\
\hline
\end{tabular}




\section{PERFORMING ORGANIZATION NAME(S) AND ADDRESS(ES) (concluded)}

U.S. Army Engineer Research and Development Center 3909 Halls Ferry Raod

Vicksburg, MS 39180-6199

\section{ABSTRACT (concluded)}

models, and (d) the functional index calibration curves developed from reference wetlands that are used in the assessment models. The guidebook outlines an assessment protocol for using the model variables and functional indices to assess each of the wetland subclasses. The appendices provide field data collection forms and spreadsheets for making calculations. 